\title{
Ground-Water Quality in Five Areas of Differing Land use in Nassau and Suffolk Counties, Long Island, New York
}

\author{
By Carolyn E. Leamond, Ralph J. Haefner, Stephen J. Cauller, and Paul E. Stackelberg
}

U.S. GEOLOGICAL SURVEY

Open-File Report 91-180

Syosset, New York 


\section{U.S. DEPARTMENT OF THE INTERIOR \\ MANUEL LUJAN, JR., Secretary}

\section{U.S. GEOLOGICAL SURVEY \\ Dallas L. Peck, Director}

For additional information write to:

U.S. Geological Survey

5 Aerial Way

Syosset, NY 11791
Copies of this report may be purchased from:

U.S. Geological Survey

Open-File Reports - ESIC

Box 25425

Denver, CO 80225 


\section{CONTENTS}

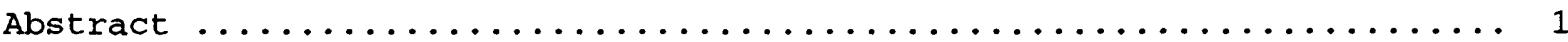

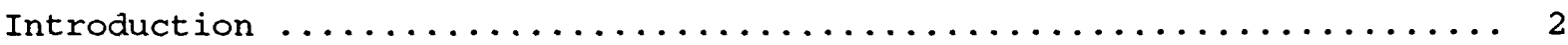

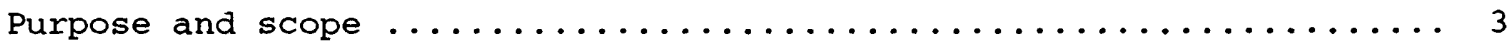

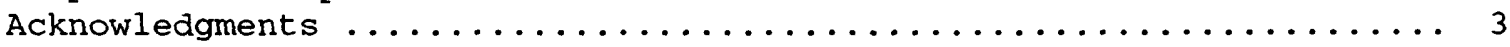

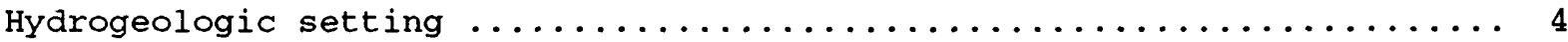

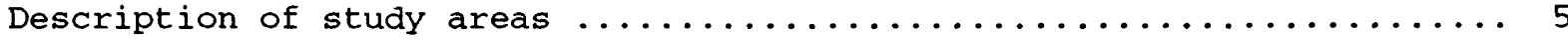

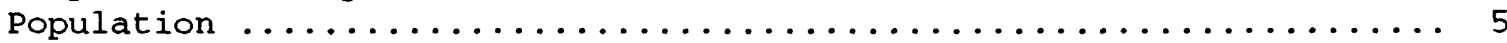

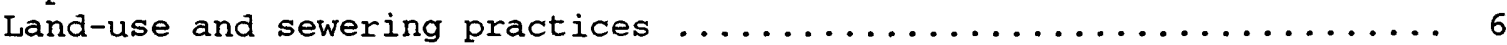

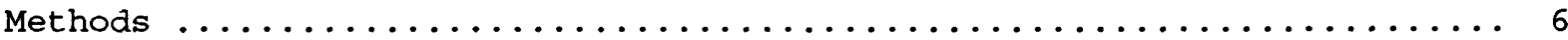

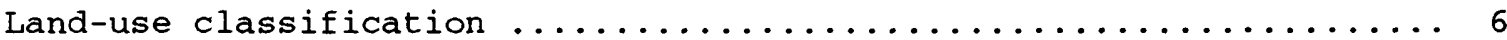

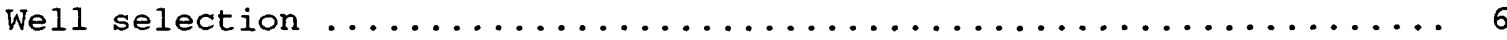

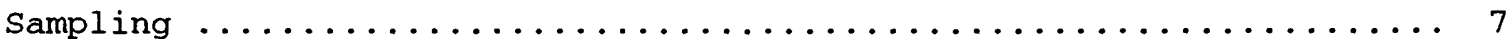

Chemical analyses and quality assurance $\ldots \ldots \ldots \ldots \ldots \ldots$

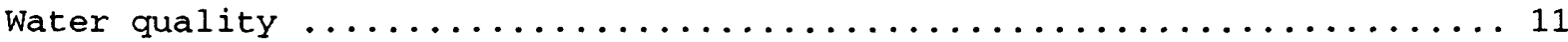

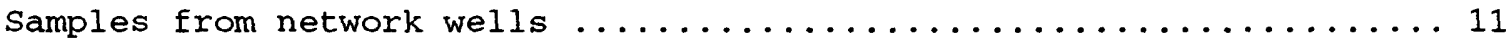

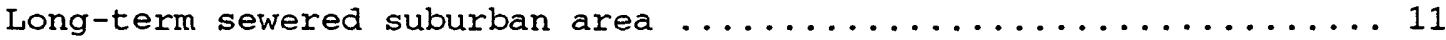

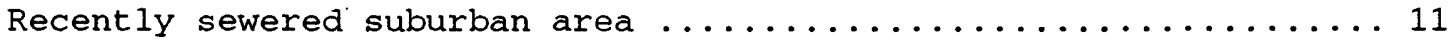

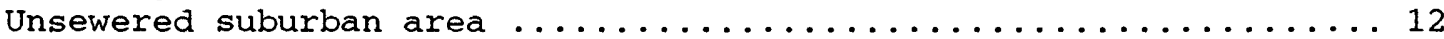

Agricultural area .............................. 12

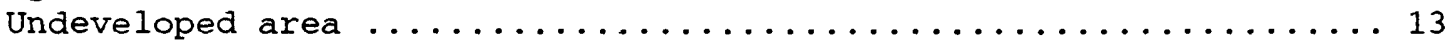

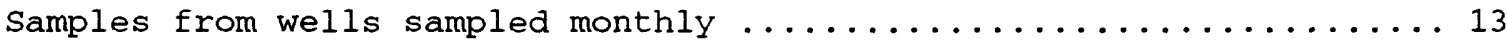

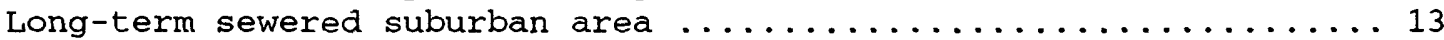

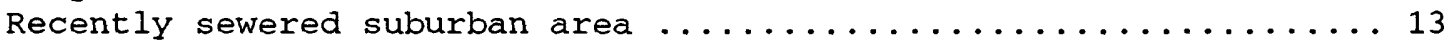

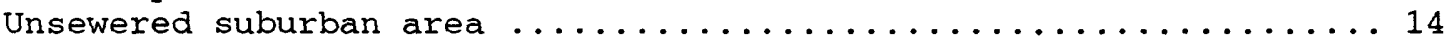

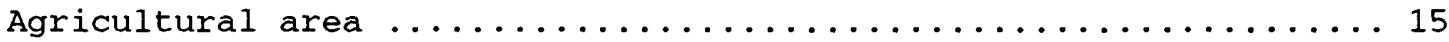

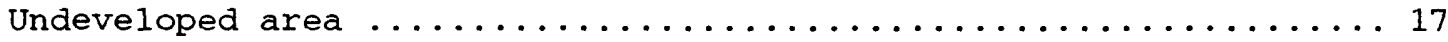

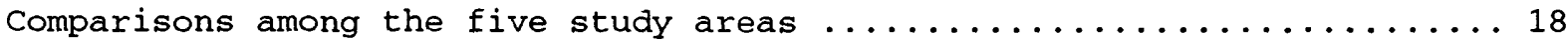

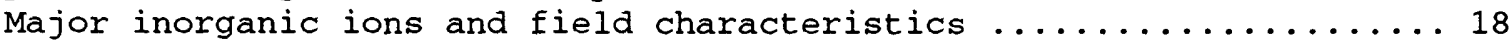

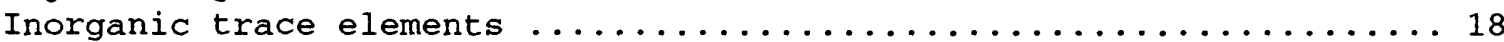

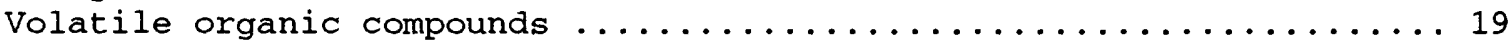

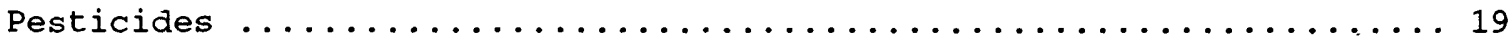

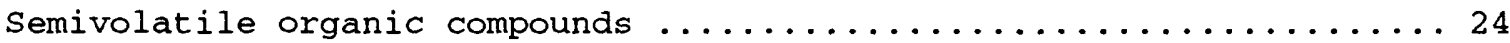

Summary ....................................... 24

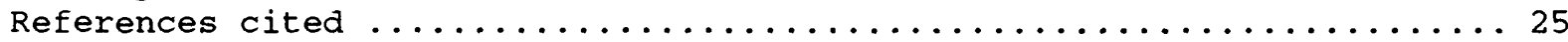

\section{ILLUSTRATIONS}

Figure 1. Map showing location of Nassau and Suffolk Counties and of the five study areas .......................... 2

2. Generalized geologic section through the Long Island

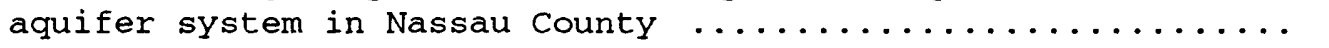

3. Maps of study areas showing locations of wells sampled in the long-term sewered and recently sewered suburban areas, unsewered suburban area, agricultural area, and undeveloped area $\ldots \ldots \ldots \ldots \ldots \ldots \ldots \ldots \ldots \ldots \ldots \ldots \ldots$ 


\section{ILLUSTRATIONS (continued)}

4. Graphs showing temporal variations in values of field characteristics and selected constituents in water samples from five wells sampled monthly:

A. Water temperature, pH, and dissolved-oxygen

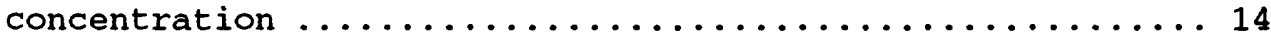

B. Alkalinity, hardness, total dissolved solids, and

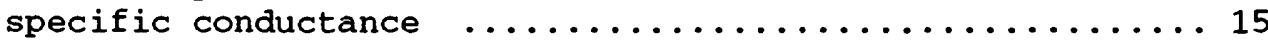

C. Calcium, magnesium, sodium, and potassium $\ldots \ldots \ldots \ldots \ldots 16$

D. Nitrate-nitrogen, sulfate, chloride, and aldicarb metabolites ............................ 17

5. Box plots showing range in values of selected field characteristics and inorganic constituents in water samples from network wells:

A. Water temperature, $\mathrm{pH}$, and dissolved-oxygen

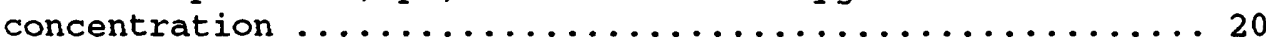

B. Alkalinity, hardness, total dissolved solids, and

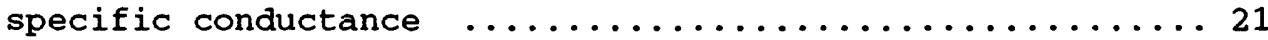

C. Calcium, magnesium, sodium, and potassium .......... 22

D. Sulfate, nitrate-nitrogen, chloride, and boron ....... 23

\section{TABLES}

Table 1. Types of land use within the five study areas $\ldots \ldots \ldots \ldots \ldots 27$

2. Well-construction data on network wells and hydrogeologic

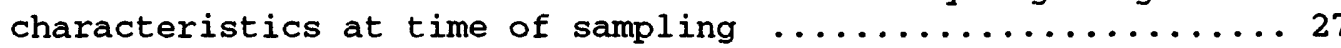

3. Inorganic and organic chemical constituents for which

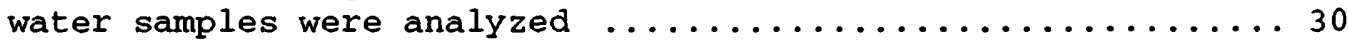

4. Major inorganic-ion concentrations and field constituent values in water samples from network wells $\ldots \ldots \ldots \ldots \ldots \ldots 32$

5. Inorganic trace-element concentrations in water samples

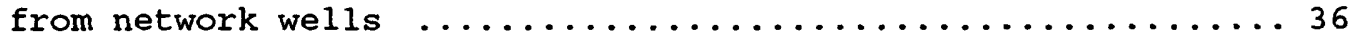

6. Volatile organic compound concentrations in water samples

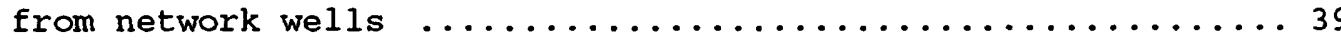

7. Volatile-organic-compound results from duplicate water samples from 13 network wells:

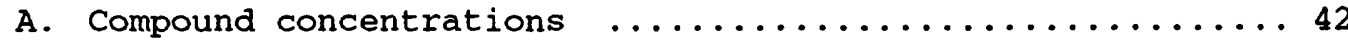

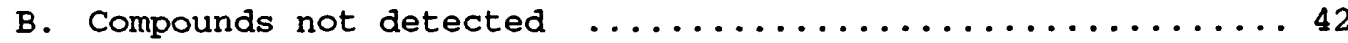

8. Organochlorine insecticide concentrations in water samples from network wells ......................... 43 


\section{TABLES (continued)}

9. Herbicides and insecticides in water samples from network wells :

A. Chlorophenoxy-acid and triazine herbicide and organophosphorus insecticide concentrations ..........45

B. Chlorophenoxy-acid and triazine herbicides and organophosphorus, organochlorine, and carbamate insecticides not detected

10. Carbamate insecticide concentrations in water samples from network wells ............................ 48

11. Semivolatile organic compounds in water samples from 24 resampled network wells:

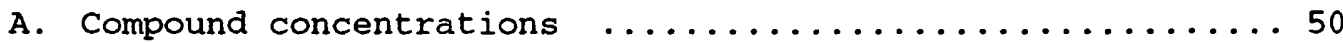

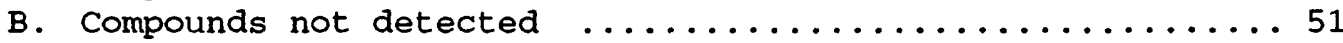

12. Chemical concentrations in water samples from wells sampled monthly:
A. Major inorganic-ion concentrations and field constituent values ...................... 52
B. Inorganic trace-element concentrations ............ 58
C. Volatile organic-compound concentrations ...........60 60
D. Volatile organic-compound concentrations in six duplicate water samples $\ldots \ldots \ldots \ldots \ldots \ldots \ldots \ldots \ldots \ldots 6$

13. Insecticides and herbicides in water samples from wells sampled monthly:
A. Organochlorine-insecticide concentrations at well in

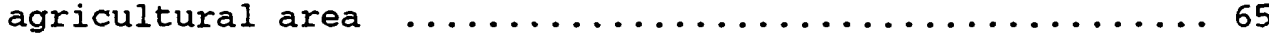
B. Carbamate-insecticide concentrations at wells in agricultural and undeveloped area ..............66
c. Organochlorine and organophosphorus insecticides and chlorophenoxy-acid and triazine herbicides not detected at well in agricultural area 


\section{CONVERSION FACTORS AND ABBREVIATED WATER-QUALITY UNITS}

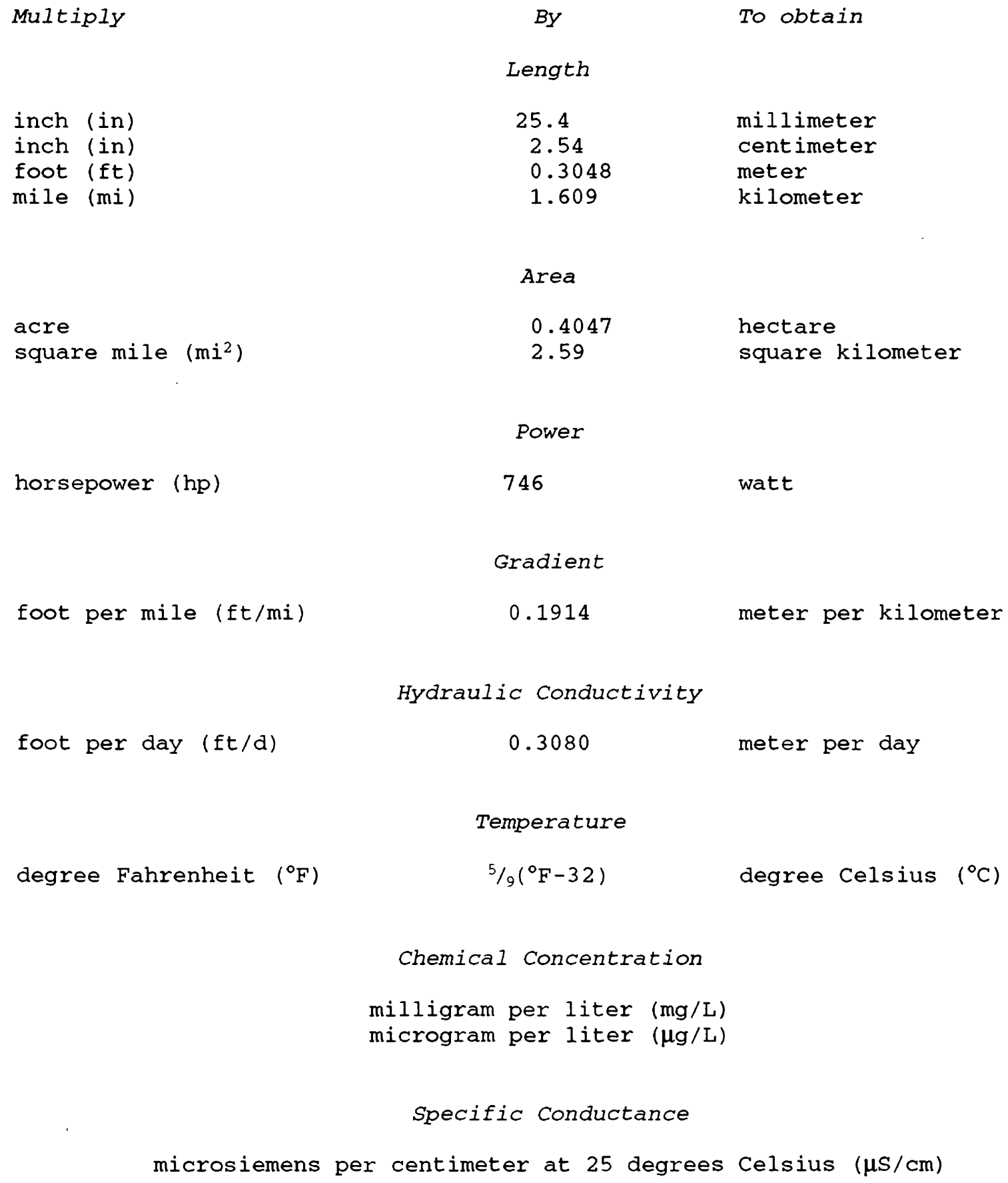




\title{
GROUND-WATER QUALITY IN FIVE AREAS OF DIFFERING LAND USE IN NASSAU AND SUFFOLK COUNTIES, LONG ISLAND, NEW YORK, 1987-88
}

\author{
By Carolyn E. LeaMond, Ralph J. Haefner, Stephen J. Cauller, \\ and Paul E. Stackelberg
}

\begin{abstract}
Water samples were collected from 90 water-table wells in five study areas in Nassau and Suffolk Counties as part of a study to relate shallow groundwater quality to land use statistically. The study areas were delineated according to predominant land use and to current and historic sewering practices. The areas included: (1) a long-term sewered suburban area (20 wells), (2) a recently sewered suburban area (20 wells), (3) an unsewered suburban area (20 wells), (4) an agricultural area (15 wells), and (5) an undeveloped area (15 wells). Additional samples were collected monthly from one well in each area for at least 1 year after initial sampling to provide a record of water-quality changes at each well.

Samples were analyzed for field characteristics and inorganic constituents; volatile and semivolatile organic compounds; organochlorine, organophosphorus and carbamate insecticides; and triazine and chlorophenoxy-acid herbicides. This report presents the chemical data in tables, graphs, and box plots.

Median water temperatures in the two sewered suburban areas were significantly higher (all significant differences determined by Tukey's Studentized Honest Significant Difference Range Test) than in the other three areas, and the median water temperature in the unsewered suburban area was significantly higher than in the agricultural or undeveloped areas. Median concentrations of calcium, sulfate, potassium, and boron were larger in the agricultural area than in the unsewered suburban area or the undeveloped area and were similar to median concentrations in the two sewered suburban areas. Median concentrations of nitrate-nitrogen, potassium, specific conductance, and total dissolved solids were smaller in the undeveloped area than in the other four areas. Median concentration of dissolved oxygen was larger in the undeveloped area than in the three suburban areas.
\end{abstract}

Volatile organic compounds (VOC's) were detected primarily in the three suburban study areas; detection was most frequent in the recently sewered suburban area, followed by the unsewered suburban area. The most commonly detected VOC's were 1,1,1-trichloroethane, trichloroethylene, and tetrachloroethylene.

Insecticides were detected primarily in suburban and agricultural areas. The most frequently detected pesticide group was the organochlorine insecticides. Carbamate insecticides, primarily aldicarb metabolites, were detected most frequently within the agricultural area and had the highest concentrations of all pesticides. Organophosphorus insecticides were detected infrequently and at low concentrations. Triazine herbicides were detected in the three suburban study areas only.

Results indicate that ground-water quality differs among the five study areas, and that the differences for several constituents are statistically significant. 


\section{INTRODUCTION}

The Long Island aquifer system is considered by the U.S. Environmental Protection Agency (USEPA) to be the sole source of potable water for about 2.6 million people in Nassau and Suffolk Counties on Long Island, N.Y. (fig. 1). The aquifer system consists of unconsolidated gravel, sand, silt, and clay deposits of Pleistocene and Cretaceous age and is bounded on the north and south by saltwater and on the bottom by crystalline bedrock. Recharge to the aquifer is through (1) rainfall that percolates through the sediments, (2) recharge basins that collect rainfall and storm-sewer runoff, and (3) septic systems.

Pumping from the upper glacial (water-table) aquifer for public supply has been restricted locally as a result of human-induced contamination and lowering of the water table; the primary source of ground water for public supply in Nassau County is the deeper Magothy aquifer (Nassau County Department of Health, 1988, p. 11). Contamination in the upper glacial aquifer, and the possibility of contaminant migration into the Magothy aquifer, have made the effects of development and land use on ground-water quality a growing public concern; therefore, data on the effects of human activities on the quality of ground water are essential to the development of land-management and watermanagement plans by state and local agencies.

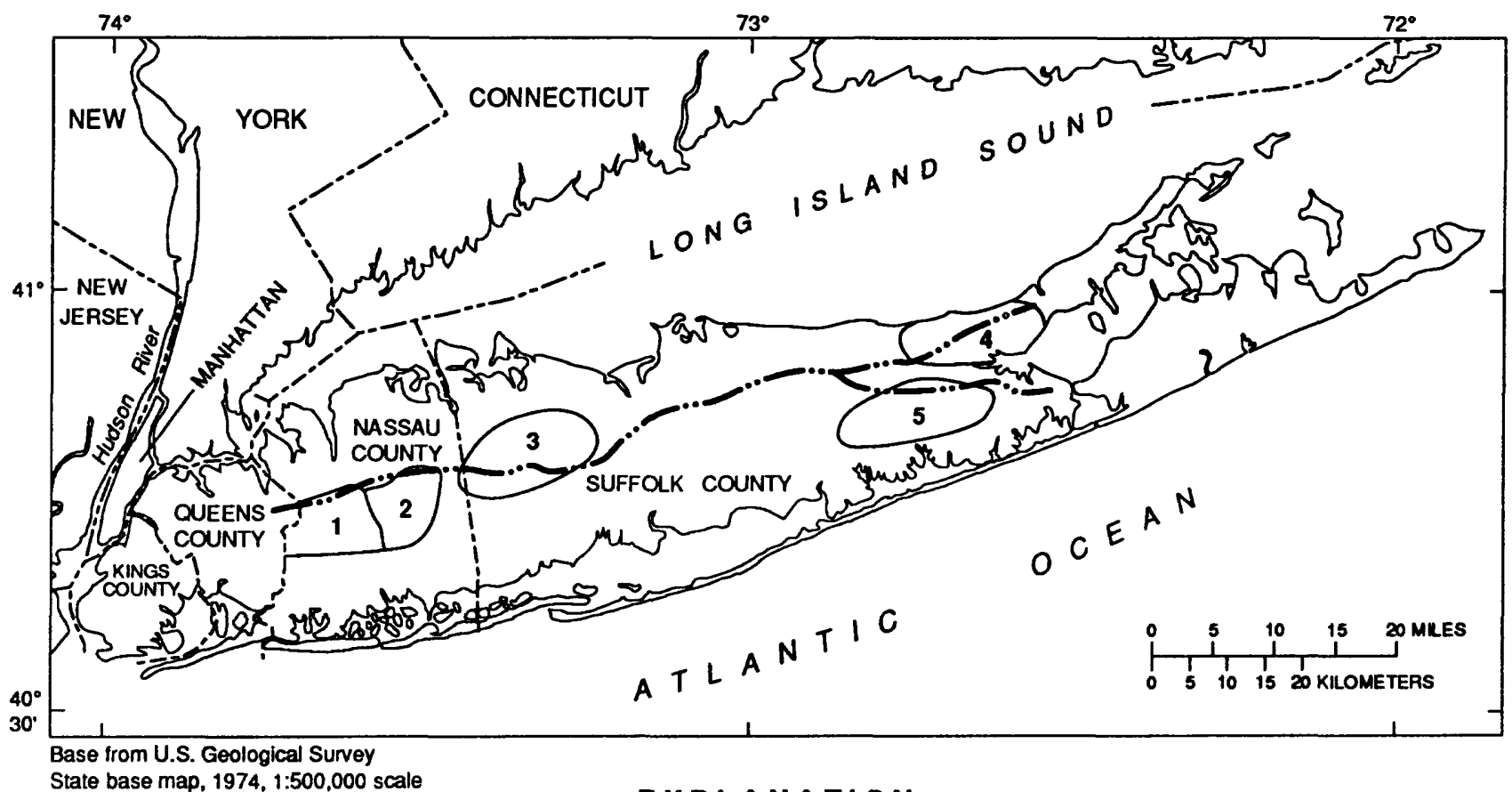

State base map, 1974, 1:500,000 scale

EXPLANATION

\begin{tabular}{|l|}
\hline 1 \\
\hline 2 \\
\hline 3 \\
\hline
\end{tabular}

Long-term sewered surburban

Recently sewered surburban

Unsewered surburban

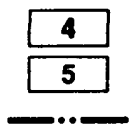

Agricultural

Undeveloped

Ground-water divide

Figure 1.--Location of Nassau and Suffolk Counties and of the five study areas. 
In 1984, the U.S. Geological Survey (USGS) began regional ground-waterquality assessments of 14 areas of the United States to assess the quality of the nation's ground water and the nature and extent of contamination and thereby provide a basis for appraising ground-water quality in other parts of the country (Helsel and Ragone, 1984). The Long Island aquifer system in Nassau and Suffolk Counties (fig. 1) was selected as part of this study because (1) a vast amount of hydrogeologic and chemical data is available, (2) the $1,170-\mathrm{mi}^{2}$ area is large enough to be of regional importance, and (3) the aquifer system is hydrologically similar to other systems in the Atlantic Coastal plain. The first phase of this project (Eckhardt and others, 1989) was a reconnaissance study to statistically evaluate and compare water-quality data from ground-water samples representing 10 categories of land use on Long Island.

The second phase of this study, in which the data presented herein were collected, was designed to statistically relate ground-water quality in 90 water-table wells in five study areas to land use. (Well locations are shown in fig. 3.) Each study area contains a unique assemblage of land-use characteristics and sewering practices. The five areas include a long-term sewered suburban area $\left(33.5 \mathrm{mi}^{2}\right)$ and a recently sewered suburban area $\left(30.2 \mathrm{mi}^{2}\right)$ in Nassau County; and an unsewered suburban area $\left(58.8 \mathrm{mi}^{2}\right)$, an agricultural area $\left(41.2 \mathrm{mi}^{2}\right)$, and an undeveloped area $\left(48.9 \mathrm{mi}^{2}\right)$ in suffolk County. Locations of the five study areas are shown in figure 1 . Each of the five areas lies on the regional ground-water divide, where the principal direction of ground-water flow is downward. Hence, contamination introduced at or near the land surface in these areas migrates deeper into the aquifer system than it would elsewhere and moves at rates largely determined by the local vertical hydraulic conductivity and gradient. Each of the 90 wells was sampled once during 1987, and one representative well in each area was sampled monthly for at least 1 year to provide a record of seasonal variability.

\section{Purpose and Scope}

This report presents and summarizes water-quality data collected during 1987-88 to statistically relate contaminant distributions to development and land use. The data are summarized in the text and presented in tables, graphs, and box plots and consist of chemical analyses of (1) samples from the 90 wells that were sampled once, and (2) samples from the five wells that were sampled monthly. The data represent inorganic constituents, volatile organic compounds (VOC's), semivolatile organic compounds, and pesticides. All tables are given at the end of the report.

\section{Acknowledgments}

Thanks are extended to Michael Alarcon and James Adamski of the Nassau County Department of Health $(\mathrm{NCDH})$ for coordinating analytical services provided by the NCDH laboratory, and to Stephen Cary of the Suffolk County Department of Health Services (SCDHS) for coordinating analytical services provided by the SCDHS laboratory. Arthur Kunz and Carole Swick of the Long Island Regional Planning Board (LIRPB) made many helpful suggestions related to the land-use-classification system. The LIRPB also provided land-use data and population statistics. The Suffolk County Water Authority provided funding for the digital automation of land-use data. 


\section{HYDROGEOLOGIC SETTING}

The aquifer system that underlies Long Island is composed of unconsolidated glacial and fluvial or deltaic deposits that unconformably overlie relatively impermeable crystalline bedrock. The bedrock surface dips gently to the southeast at an average slope of $65 \mathrm{ft} / \mathrm{mi}$ (McClymonds and Franke, 1972, and Soren and Simmons, 1987). The total thickness of overlying sediments is approximately $2,000 \mathrm{ft}$ in south-central suffolk County and decreases toward the north shore, where bedrock is exposed on the far northwest corner of the island (McClymonds and Franke, 1972, and Soren and Simmons, 1987). The sediments consist of mixtures of Pleistocene and Cretaceous gravel, sand, silt, and clay (fig. 2). The upper glacial aquifer and upper part of the Magothy aquifer are the only parts of the Long Island aquifer system that are relevant to this study; neither the deeper parts of the Magothy nor the underlying Raritan Clay nor the Lloyd aquifer are discussed.

The upper glacial aquifer consists of pleistocene glacial moraine and outwash deposits. The thickness ranges from $0 \mathrm{ft}$ to more than $600 \mathrm{ft}$ in northeastern Nassau County and northwestern Suffolk County (McClymonds and Franke, 1972). In general, the thickness is greatest along the north shore and gradually decreases toward the southern shore. The water table lies within the upper glacial aquifer throughout most of Long Island but intersects the underlying Magothy aquifer in parts of northeastern Nassau and northwestern Suffolk Counties and in areas where the upper glacial aquifer is absent.

The average horizontal hydraulic conductivity within the upper glacial aquifer is $270 \mathrm{ft} / \mathrm{d}$ but may be greater within outwash deposits along the south shore, where coarse sand and gravel are abundant (Franke and Cohen, 1972). Localized clay units within the upper glacial aquifer have been identified and

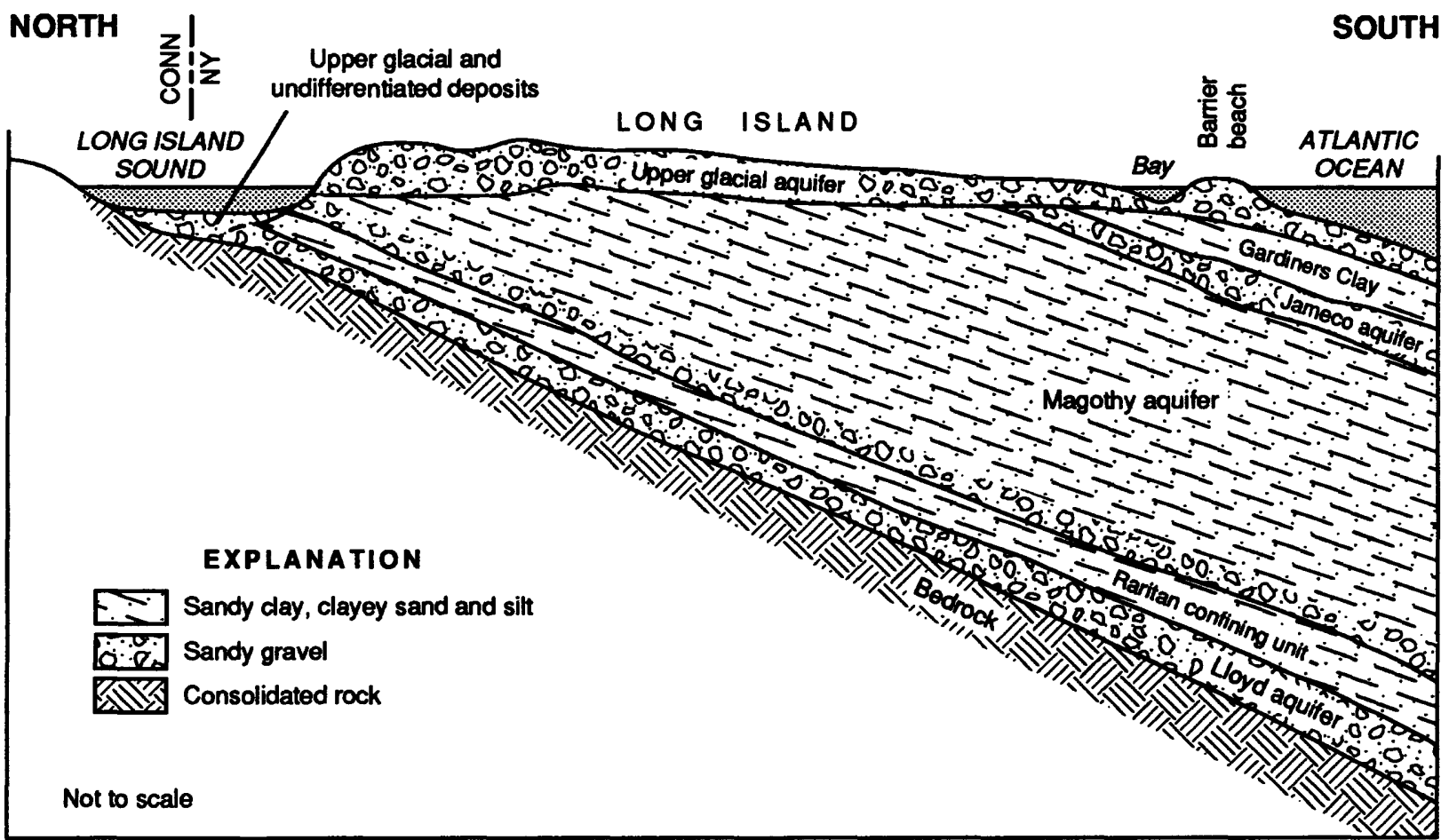

Figure 2.--Generalized geologic section through the Long Island aquifer system in Nassau County. (Modified from MCClymonds and Franke, 1972, fig. 3.) 
include the "Manorville clay" (Lubke, 1964), the "Smithtown clay" (Lubke, 1964), and the "20-foot clay" (Doriski and Wilde-Katz, 1983). These clay units tend to retard the vertical movement of ground water and may locally separate deeper zones of the aquifer from the water-table aquifer.

The Magothy aquifer, which underlies the upper glacial aquifer, consists of Cretaceous fluvial or deltaic sediments of fine to medium sand with some lenses of coarse sand and sandy to solid clay (McClymonds and Franke, 1972). The Magothy and upper glacial aquifer commonly are considered to be. hydraulically continuous except in areas on the south shore, where they may be separated by the Gardiners Clay; the Gardiners Clay does not extend beneath any of the five study areas, however. The thickness of the Magothy aquifer ranges from about $100 \mathrm{ft}$ along the north shore to $1,000 \mathrm{ft}$ near the south shore in Suffolk County (McClymonds and Franke, 1972, Soren and Simmons, 1987).

The horizontal hydraulic conductivity of the Magothy aquifer generally is much lower than that of the upper glacial aquifer and averages about $50 \mathrm{ft} / \mathrm{d}$ (Franke and Cohen, 1972). Localized clay lenses are also present within the Magothy aquifer, but their location and extent have not been delineated. The clay lenses are not extensive but may retard downward movement of water, as do the clay units within the upper glacial aquifer.

The aquifer system is recharged primarily by precipitation, which averages $44 \mathrm{in} / \mathrm{yr}$. Franke and Cohen (1972) estimate that about half the precipitation (21 in/Yr) reaches the ground-water system. Water that infiltrates the ground near the regional ground-water divide (fig. 1) flows downward and recharges the deeper aquifers and eventually discharges along the shores into Long Island Sound and (or) the At lantic Ocean; water that enters far from the divide flows seaward with a greater horizontal component.

\section{DESCRIPTION OF STUDY AREAS}

The five study areas each have a unique assemblage of land use and population history. Two of the study areas are in Nassau County, and three are in Suffolk County. Each study area lies approximately on the ground-water divide.

\section{Population}

By the early 1900 's, New York City had begun to expand into Kings and Queens Counties on western Long Island, but Nassau and Suffolk Counties remained rural. After World War II and into the 1950s, extensive migration from New York City into Nassau County caused a sharp population increase. By 1970, the population of Nassau County had reached 1.4 million but, by 1980 , had decreased slightly to 1.3 million, the same as in 1960 . The downward trend in population during 1970-80 was due largely to migration to the more rural Suffolk County. Suffolk County's population grew at a slower rate than Nassau County's until 1950, then quadrupled between 1950 and 1970. Unlike Nassau County, Suffolk County's population continued to grow through the 1970's, although at a reduced rate, and reached $1.3 \mathrm{million}$ in 1980 (Long Island Regional Planning Board, 1982b).

The highest population density in the five study areas is in the sewered suburban areas of Nassau County (10 to 14 people per acre). Generally, the population density decreases eastward. Population density in the unsewered suburban area in western Suffolk County, which is mainly dense residential 
development, is about 6 per acre. Population densities in the agricultural and undeveloped areas are less than 1 per acre (U.S. Bureau of the Census, $1980)$.

\section{Land Use and Sewering Practices}

The three suburban study areas differ from each other in sewering practices. The long-term sewered suburban area began hookups to regional sewage-treatment facilities in 1955 and completed the work in 1965 (Mark Maimone, Nassau County Department of Public Works, oral commun., 1989); the recently sewered suburban area began hookups to regional sewage-treatment facilities in 1980 and completed the work in 1987 . The unsewered suburban area and the agricultural and undeveloped areas continue to dispose of sewage primarily through onsite septic tanks or cesspools. Before the installation of regional sewage-treatment facilities in Nassau County, all sewage disposal was through onsite systems.

\section{METHODS}

The study involved quantification of a land-use classification system, selection and sampling of wells, water-quality analyses, and development of a quality-assurance procedure, as described below.

\section{Land-Use Classification}

Classification of the five study areas was based on the predominant land use and sewering characteristics within each area. Land-use information for Nassau and Suffolk Counties was mapped and tabulated at a scale of 1:24,000 by the Long Island Regional Planning Board (1982a) from 1980 aerial photographs. That information was classified into 12 land-use categories in accordance with the classification developed for the $1966 \mathrm{Bi}$-county Comprehensive Plan (Long Island Regional Planning Board, 1982a). Photographic copies of the original 1980-81 hand-colored land-use maps were digitized, coded, and stored in a computerized geographic information system (GIS) format to permit spatial analysis of this information. Overlaying study-area boundaries onto the digitized land-use maps enabled identification and quantification of the predominant land use within each study area (table 1, at end of report).

\section{Well Selection}

A network of 90 water-quality-monitoring wells was designed to provide chemical data that are representative of shallow ground-water quality in each of the five study areas. Each well was sampled once during 1987 . The three suburban areas had 20 wells each, all screened in the upper glacial or upper Magothy aquifer, and the agricultural and undeveloped areas had 15 wells each, all screened in the upper glacial aquifer. Locations of the 90 wells are shown in figure 3 (p. 8-9).

The first step in the well-selection procedure was to identify shallow monitoring wells in the USGS data base for each of the study areas. For the purpose of this investigation, a shallow well was defined as a water-table well having a screen depth of less than $45 \mathrm{ft}$ below the water table. Wells were then chosen from this group by a process of random selection wherein a grid was superimposed over a well map of each study area. The grid was used 
to ensure uniform spatial representation of samples. The number of grid cells in each study area corresponded to the desired number of wells in each area (20 or 15), and size depended on the size of the study area and the number of grid cells. The wells within each grid cell were randomly numbered, and the lowest numbered well in each cell that was suitable for sampling was selected.

All wells selected for sampling were monitoring wells owned by the USGS, Nassau County Department of Public Works, or Suffolk County Water Authority. The advantage of using monitoring wells (as opposed to public-supply or industrial-supply wells) is that well evacuation and sampling could be done consistently by methods described further on. The wells range in diameter from 2 to 6 in. Pertinent well characteristics are summarized in table 2.

One of the wells in each area was selected for additional monthly sampling, and sampling was continued for at least 1 year after initial sampling to establish a record of seasonal fluctuation in ground-water quality at these five wells. These wells were selected to provide values representative of the respective study areas and were selected according to initial sampling results.

\section{Sampling}

Methods of sample collection were designed to provide accurate and representative samples from the shallow ground-water system. The 90 wells were each sampled once during June-October 1987; the monthly well sampling continued through December 1988.

Water levels were measured before pumping for entry into the Geological Survey's data base and to calculate casing volumes. A 2-in-diameter, stainless-steel submersible pump with $1 / 2$-in Teflon ${ }^{1}$ discharge tubing was used for well evacuation and sampling. The pump was placed $5 \mathrm{ft}$ above the top of the well screen, and at least three casing volumes were pumped before sampling. A 1 -HP seven-stage submersible pump with polyvinyl chloride (PVC) flush thread pipe and Teflon sampling tube was used at three wells where the small-diameter pump was not adequate to evacuate the well; these wells are S-73811, S-46283, and S-75456 (the first is in the undeveloped area, and the second two are in the unsewered suburban area; see fig. 3 ).

The Teflon sampling tube was equipped with a smaller diameter Teflon variable-flow tube designed to minimize aeration and exposure to the atmosphere during sampling and thereby minimize volatilization of certain organic constituents or escape of dissolved gasses that may have been present in the sample. This sampling tube was used to collect samples for VOC analysis and field measurement of dissolved oxygen.

Samples were taken at the pump discharge for measurement of temperature, $\mathrm{pH}$, and specific conductance at about 15-minute intervals. Stable measurements of these field measurements were required before sample collection. The $\mathrm{pH}$ was required to have stabilized to within $0.05 \mathrm{pH}$ units, and the temperature to within $0.1{ }^{\circ} \mathrm{C}$ between two successive measurements.

Dissolved oxygen was measured at the time of sampling by the winkler titration method (Brown and others, 1970). The method was modified slightly in that half the required amount of sample water was used, and the resulting values were multiplied by 2 .

1 Use of brand names is for identification purposes only and does not constitute endorsement by the U.S. Geological survey. 


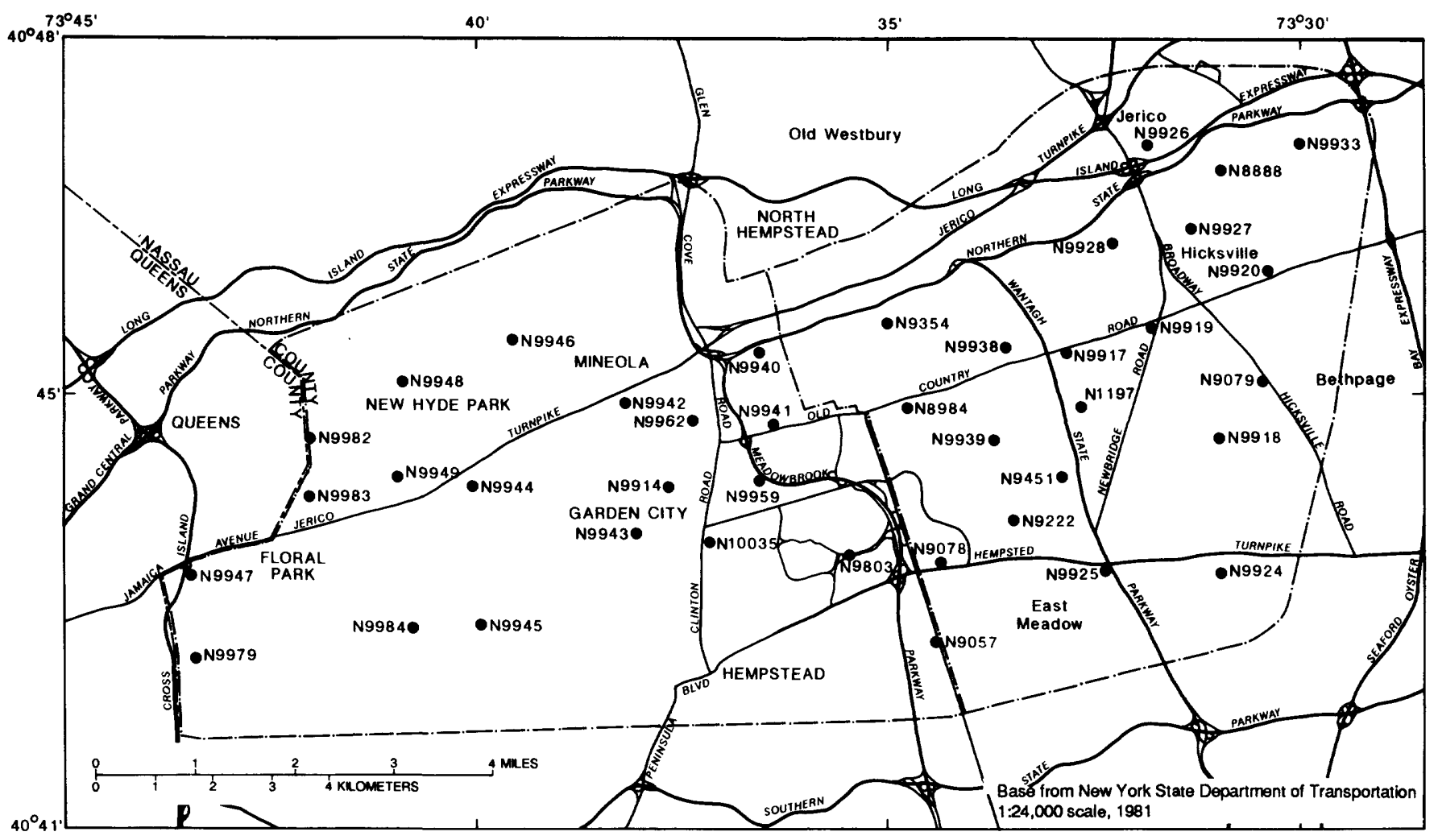

Long-term sewered (westernmost) area and recently sewered suburban area

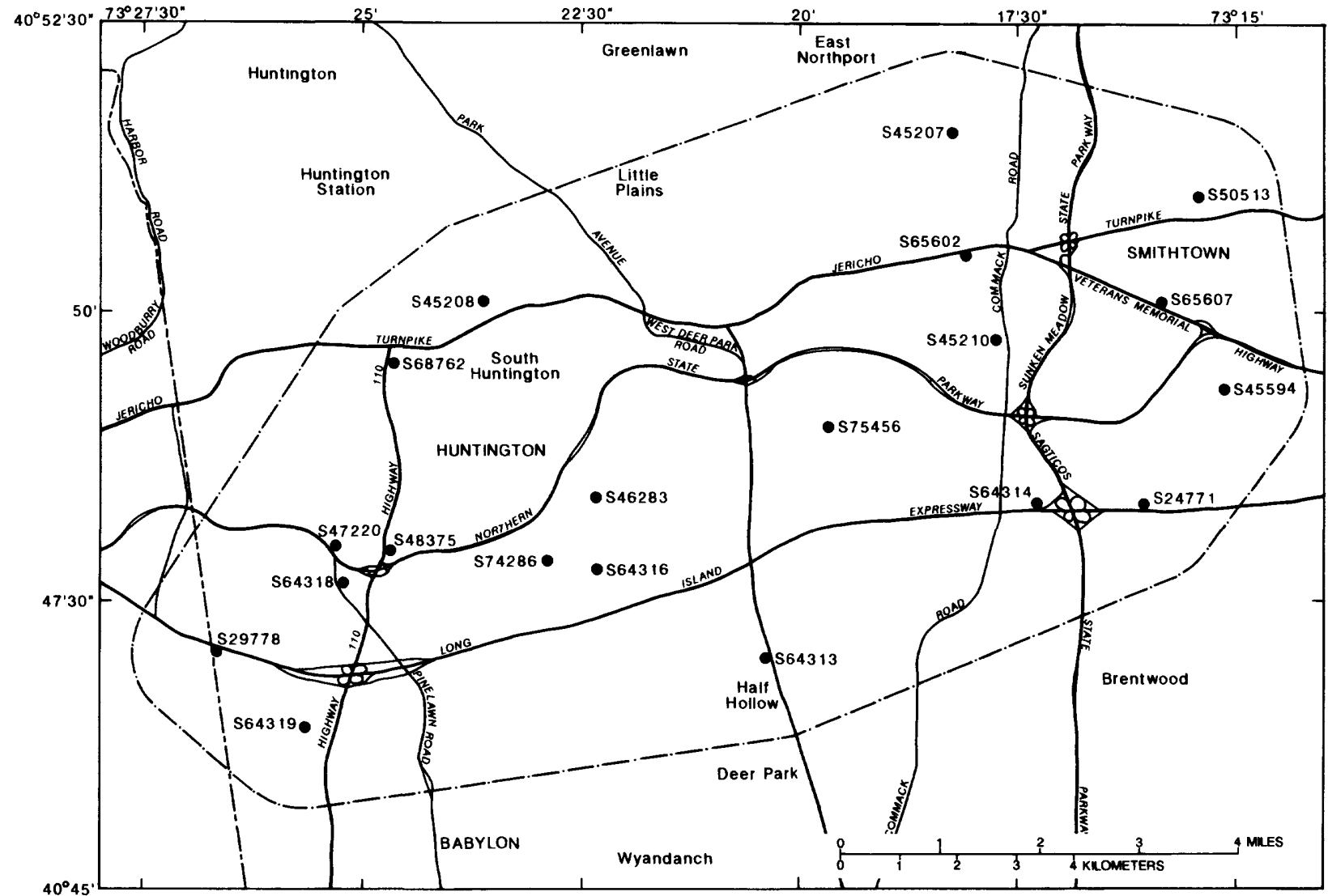
Base from New York State Department of Transportation Unsewered suburban area
1:24,000 scale, 1981

Figure 3.--Locations of wells sampled in the five study areas. (Study-area locations are shown in fig. 1). 


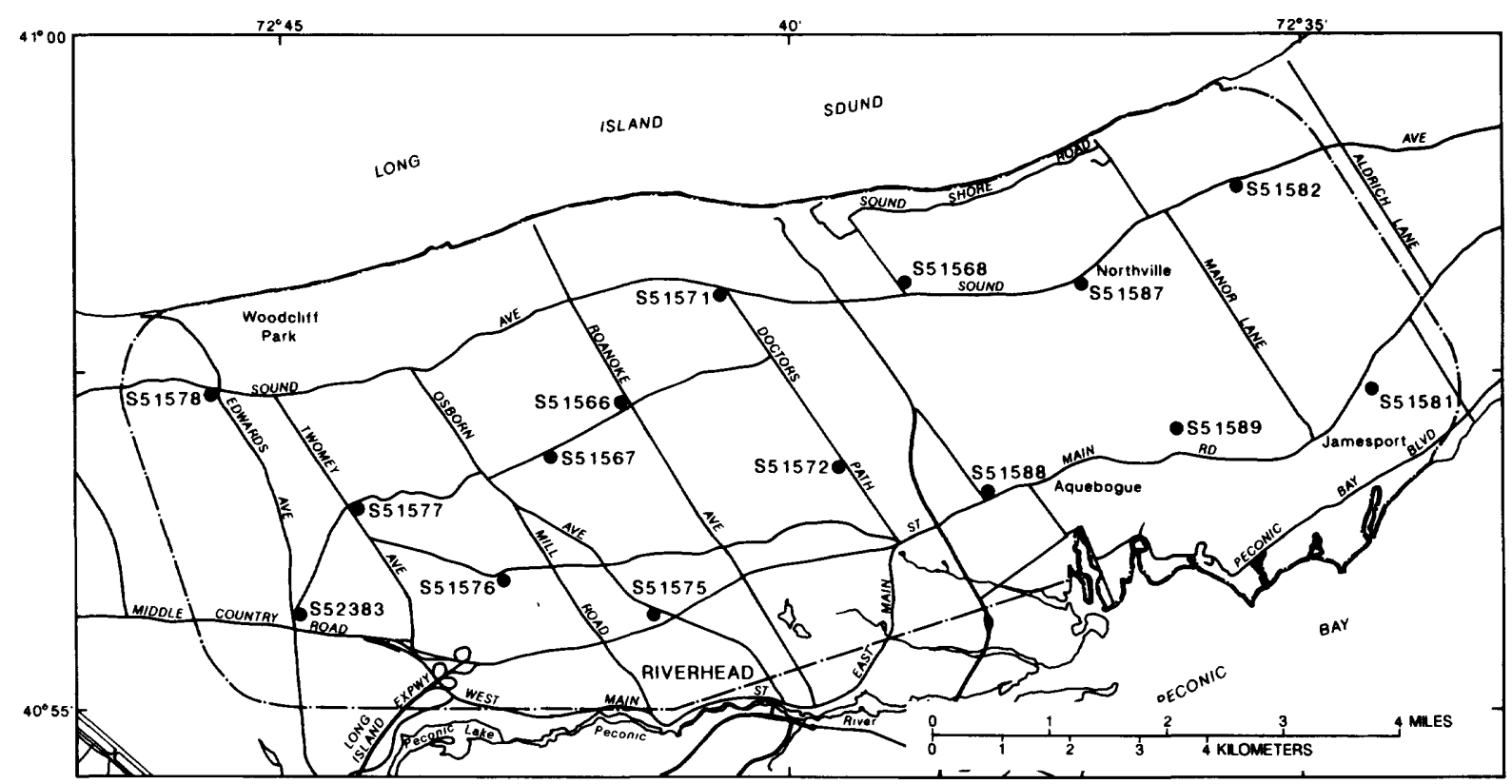

Base from New York State Department of Transportation 1:24,000 scale, 1981

Agricultural area

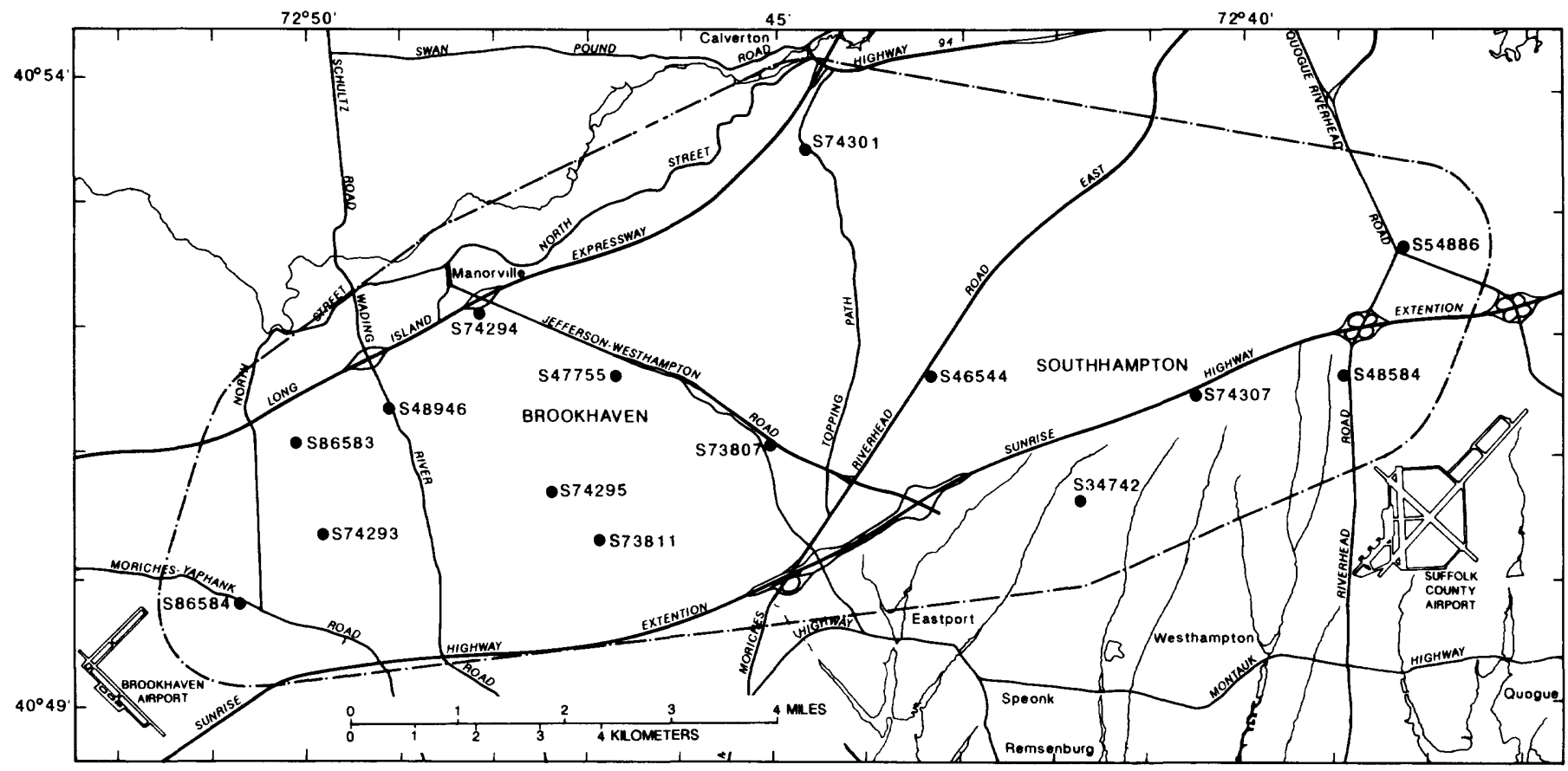

Base from New York State Department of Transportation 1:24,000 scale, 1981

\section{Undeveloped area}

EXPLANATION

- N9948 OBSERVATION WELL-

Number is county well number

- - STUDY-AREA BOUNDARY

Figure 3.--Locations of wells sampled in the five study areas (continued). 
Sample-collection procedures differed according to the type of analysis. Samples for major inorganic ion analysis were not filtered. Samples for dissolved metals and dissolved boron analyses were filtered and acidified in the field with nitric acid. Samples for base-neutral and acid-extractable compound analyses were treated with mercuric chloride at the time of sampling to prevent biodegradation of organic compounds.

Samples were chilled immediately after collection and delivered to the NCDH laboratory within 4 days of collection. Samples analyzed by either the NWQL or the USGS laboratory in Ocala, Fla. were sent by overnight mail within 4 days of collection. Samples for analysis of carbamate pesticides were frozen upon return to the USGS office in Syosset and delivered to SCDHS laboratory within 4 days of collection.

\section{Chemical Analyses and Quality Assurance}

A list of inorganic chemicals and organic compounds for which ground-water samples were analyzed is given in table 3. The Nassau County Department of Health (NCDH) laboratory provided analytical services for volatile organic compounds (VOC's) and all inorganic constituents except boron, which was done by the National Water Quality Laboratory (NWQL) of the USGS in Arvada, Colo. The Suffolk County Department of Health Services (SCDHS) laboratory provided analyses for carbamate pesticides. Both NCDH and SCDHS laboratories participate in the USGS standard-reference water-sample program. Analyses for organochlorine and organophosphorus insecticides and triazine and chlorophenoxy-acid herbicides were done by NWQL.

In addition to VOC analyses by NCDH laboratory, duplicate samples for VOC analyses were collected at all 90 wells and at the single well in each area that was sampled monthly and analyzed by the USGS in syosset by purge and trap liquid-sample concentration and gas chromatography with flame-ionization detection (GC-FID). Qualitative information from these analyses were used as a screening method to select 13 duplicate samples from the 90 -well network, and six duplicate samples from the wells sampled monthly for voc analysis by GC-MS (gas chromatography with mass spectroscopy) by the NWQL. The duplicate samples selected for analysis by NWQL were those with relatively high concentrations of VOC's, as indicated by GC-FID scans.

The detection limit for all VOC's analyzed by NWQL was $0.2 \mu \mathrm{g} / \mathrm{L}$, about 1 order of magnitude lower than the detection limits achieved by NCDH laboratory, which range from 1 to $10 \mu \mathrm{g} / \mathrm{L}$. Thus, the NWQL analyses provide quantitative information for water samples with small voC concentrations that NCDH laboratory reported as less than detection limits. This provides a means of assessing the value of analyzing for certain constituents at relatively high levels, as well as for comparing results among laboratories, and thereby provides a measure of quality assurance. Analysis by NWQL included 35 VOC's and analysis by NCDH laboratory included 16 VOC's. All VOC's analyzed by NCDH laboratory were also analyzed by NWQL except for trichlorofluoromethane, which was analyzed only by the NCDH laboratory.

Samples from 90 wells were analyzed for presence of methylene chlorideextractable compounds (including semivolatiles) through GC-FID by the USGS lab in Ocala, Fla. This qualitative information was used as a screening method to identify wells to be resampled for quantitative analysis for semivolatile organic compounds by NWQL through GC-MS methods. Wells at which concentrations were indicated by GC-FID scans to range over $20 \mu \mathrm{g} / \mathrm{L}$ or more were resampled. 


\section{WATER QUALITY}

Samples from network wells were analyzed for inorganic constituents; volatile organic compounds, organochlorine, organophosphorus, and carbamate insecticides; chlorophenoxy-acid and triazine herbicides; and semivolatile organic compounds (qualitative analysis of 90 samples and quantitative analysis of 24 samples). Samples from wells sampled monthly in each study area were analyzed for major inorganic ions, trace inorganic elements, and VOC's; those from the agricultural area and undeveloped area also were analyzed for carbamate pesticides; and those from the agricultural area were additionally analyzed for organochlorine and organophosphorus insecticides, triazine herbicides, and chlorophenoxy-acid herbicides.

\section{Samples from Network Wells}

Results of analyses for inorganic constituents, VOC's, semivolatile organic compounds, and pesticides in samples from the 90-well network are presented in tables 4 through 11 . This section summarizes detection frequencies of VOC's, pesticides, and semivolatile compounds in each study area.

\section{Long-Term Sewered Suburban Area}

VOC's were detected in samples from 10 of the 20 wells sampled in this area (table 6). The most frequently detected VOC in samples from this area, tetrachloroethylene (PCE), was detected in 5 samples, trichloroethylene (TCE) was detected in 4 samples, and 1,1,1-trichloroethane (TCA) was detected in 3 samples. Chloroform, chlorobenzene, and carbon tetrachloride also were each detected in 1 sample. The highest VOC concentration was $25 \mu \mathrm{g} / \mathrm{L}$ PCE. Duplicate samples from five wells were analyzed by the NWQL (table 7A); results indicated detectable chloroform in samples from all five wells and detectable TCA in samples from four wells. The highest concentration of TCE was $17 \mu \mathrm{g} / \mathrm{L}$.

Organochlorine insecticides were detected in samples from 10 of the wells in this area (table 8 ). The most frequently detected compound was dieldrin (seven samples), followed by chlordane and heptachlor epoxide (four samples each). The largest concentration detected of these compounds was $1.3 \mu \mathrm{g} / \mathrm{L}$ chlordane. The triazine herbicides simazine and atrazine were detected, as were the chlorophenoxy-acid herbicides 2,4-D and silvex (table 9). Neither organophosphorus nor carbamate pesticides (tables 9, 10) were detected in this area.

Thirteen wells were resampled for analysis of semivolatile organic compounds by NWQL; bis(2-ethylhexyl) phthalate was detected in one sample at the detection limit of $5 \mu \mathrm{g} / \mathrm{L}$ (table $11 \mathrm{~A}$ ).

\section{Recently Sewered Suburban Area}

VOC's were detected in samples from 14 of the 19 wells sampled in this area (VOC analysis results for one sample were not received) (table 6). TCA, the most frequently detected VOC, was detected in 13 of the 19 samples. TCE and PCE, the second most frequently detected compounds, were each detected in 5 samples. High concentrations of TCA $(12,000 \mu \mathrm{g} / \mathrm{L}), \mathrm{TCE}(390 \mu \mathrm{g} / \mathrm{L})$, benzene $(210 \mu \mathrm{g} / \mathrm{L})$, and $\mathrm{PCE}(89 \mu \mathrm{g} / \mathrm{L})$ were detected in this area. Trans-1,2-

dichloroethylene was detected in three of the samples. 1,1-Dichloroethane was detected in two samples, and benzene, chloroform, 1,1,2-trichloroethane, and 
xylene were each detected in one sample. Analysis of duplicate samples from three wells by NWQL all indicate detectable amounts of TCA, PCE, and TCE (table 7A). Chloroform was detected in two of the three samples.

The most frequently detected organochlorine insecticide was dieldrin, which was detected in 16 out of 20 samples. Chlordane was detected in 12 samples, and heptachlor epoxide was detected in 5 samples (table 8). The triazine herbicides simazine, atrazine, and prometone, the chlorophenoxy-acid herbicide 2,4-D, and the organophosphorus insecticide diazinon also were detected in samples from this area (table 9). Carbamate pesticides were not detected (table 10).

Two of the wells in this area were selected for resampling for analysis of semivolatile compounds by NWQL; naphthalene and bis(2-ethylhexyl) phthalate each were detected in one well (table 11A).

\section{Unsewered Suburban Area}

VOC's were detected in samples from 8 of the 20 wells (table 6). The most frequently detected VOC's were TCA, detected in 8 samples, TCE, detected in 4 samples; and 1,1-dichloroethane, detected in 3 samples. The highest Voc concentration detected was $290 \mu \mathrm{g} / \mathrm{L}$ TCE. VOC analysis of duplicate samples from five wells by NWQL (table 7A) detected two VOC's (1,2-dichloroethane and 1,1-dichloroethylene) that were not analyzed for by NCDH laboratory and that were detected only in samples from wells in this area. Analysis of the five duplicate samples by NWQL also detected chloroform, 1,1-dichloroethane, PCE, TCA, TCE, trans-1,2-dichloroethylene, and 1,1,2-trichloroethane.

Three organochlorine insecticides were detected in 5 of the 20 samples from this area (table 8)--dieldrin, chlordane, and heptachlor epoxide; three triazine herbicides (promtone, simazine, and atrazine) also were detected (table 9A), as were the chlorophenoxy-acid herbicide 2,4-D and the organophosphorus insecticide diazinon (table 9A). Carbofuran, a carbamate pesticide, was detected in one well at the detection limit (table 10).

Five of the wells in this area were resampled for semivolatile organic compounds by NWQL. Results indicated the presence of di-n-octylphthalate and bis(2-ethylhexyl) phthalate in two samples (table 11A).

\section{Agricultural Area}

VOC's were not detected in the 15 samples analyzed by NCDH laboratory (table 6). Organochlorine insecticides were detected in all 14 samples analyzed (organochlorine results for one sample in this area were not received) (table 8 ). The most frequently detected compound was heptachlor epoxide, which was detected in 7 of the 14 samples. Dieldrin, endosulfan, and DDD were detected in 5 samples. The chlorophenoxy-acid herbicide 2,4-D, and ethion, an organophosphorus insecticide, were each detected in one sample from this area (table 9A). Aldicarb sulfoxide and aldicarb sulfone were the most frequently detected carbamate insecticides (detected in 10 of 15 samples) and were detected at higher concentrations than any pesticide in this area (table 10).

Resampling of four of these wells for semivolatile compounds by NWQL resulted in the detection of bis(2-ethylhexyl) phthalate at $12.0 \mu \mathrm{g} / \mathrm{L}$ in one well (table 11A). 


\section{Undeveloped Area}

VOC analyses by the NCDH laboratory detected chloroform at the detection limit in 1 sample (table 6 ). The organochlorine insecticide endosulfan also was detected in 1 sample (table 8 ), but no chlorophenoxy-acid herbicides, triazine herbicides, or organophosphorus insecticides were detected (tables 8 , 9A, 9B). Aldicarb sulfoxide, aldicarb sulfone, and carbofuran were each detected in 1 sample (table 10). One well in this area was resampled for analysis for semivolatiles by NWQL, but no detections were reported (table 11A).

\section{Samples from Wells Sampled Monthly}

One well in each study area was sampled monthly to evaluate temporal variability of water quality at each well. This section discusses the results of water-quality analyses and temporal variability at these five wells and includes a summary of water-quality data.

Concentrations of inorganic ions and trace elements, and field measurements of $\mathrm{pH}$, temperature, dissolved oxygen, and specific conductance in samples from the five wells, are given in tables $12 \mathrm{~A}$ and $12 \mathrm{~B}$. Results of VoC analyses by NCDH laboratory are given in table $12 \mathrm{C}$, and results of VOC analysis by NWQL for six samples from four of the wells sampled monthly are given in table 12D. Results of the agricultural area's monthly analyses for organochlorine and carbamate insecticides are given in tables $13 \mathrm{~A}$ and $13 \mathrm{~B}$. Organochlorine and organophosphorus insecticides, and chlorophenoxy-acid and triazine herbicides not detected in water samples from the agricultural area's monthly well, are listed in table 13C. Temporal changes in concentrations of selected constituents at these wells are plotted in figure 4 .

\section{Long-Term-Sewered Suburban Area}

Well N-9984 was sampled initially in September 1987 and monthly throughout 1988. Examination of the temporal changes at this well indicates low variability for all inorganic constituents and field characteristics except temperature and alkalinity (fig. 4A). Temperature reached a minimum during January and a maximum during July; alkalinity concentrations fluctuated from 10 to $19 \mathrm{mg} / \mathrm{L}$ as $\mathrm{CaCO}_{3}$.

The only VOC detected in the NCDH Laboratory analysis of samples from this well was TCA, which was found in 10 of the 13 samples (table 12C). One sample from this well was analyzed for VOC's by NWQL, and TCA, PCE, and chloroform were detected at levels lower than NCDH laboratory detection limits (table 12D) .

\section{Recently Sewered Suburban Area}

Well N-9939 was sampled monthly from September 1987 through December 1988. Examination of temporal changes at this well indicates low variability for all inorganic constituents and field characteristics except temperature. Temperature reaches a minimum during January and a maximum during June (fig. 4A).

Analysis by the NCDH laboratory detected six VOC's in samples from this well (table 12C). PCE, which was detected in all 16 samples, and trans-1,2dichloroethylene, which was detected in 12 of 16 samples, were detected at concentrations as large as $14 \mu \mathrm{g} / \mathrm{L}$. TCA and TCE were each detected in 13 of 16 samples, but at smaller concentrations. Chloroform was detected in three samples, and 1,1-dichloroethane was detected in one sample. Two samples from this well were analyzed for VOC' $s$ by NWQL, and eight VOC's were detected in 
each (table 12D). The largest concentrations detected were $11 \mu \mathrm{g} / \mathrm{L}$ trans-1,2dichloroethylene and $7.6 \mu \mathrm{g} / \mathrm{L}$ PCE. Also detected were TCA, TCE, 1,1-dichloroethane, toluene, chloroform, and 1,1-dichloroethylene.

\section{Unsewered Suburban Area}

Well S-50513 was sampled monthly from July 1987 through December 1988. Examination of the temporal changes at this well indicates low variability for all inorganic constituents and field characteristics except for temperature (fig. 4A). Temperature reached a maximum during May 1988 and a minimum during November 1988 .

Analysis for VOC's by NCDH laboratory detected TCA in all samples from this well; the maximum concentration was $11 \mu \mathrm{g} / \mathrm{L}$ (table 12C). Chloroform was
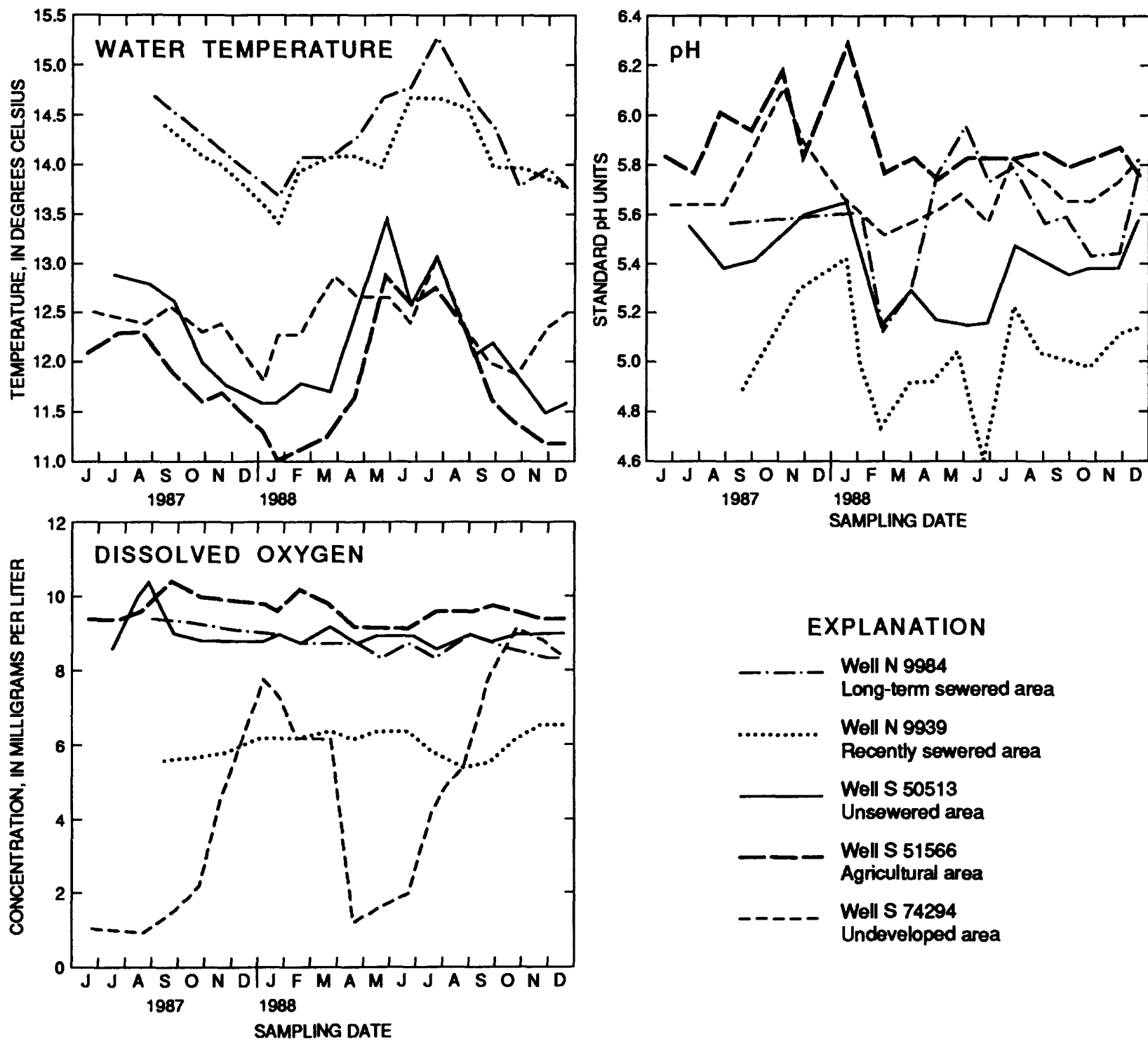

EXPLANATION

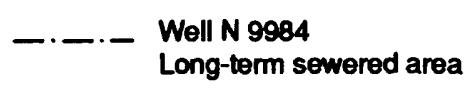

Well N 9939

Recently sewered area

Well S 50513

Unsewered area

Well S 51566

Agricultural area

Well S 74294

Undeveloped area

Figure 4A. Temporal variations in water temperature, $p H$, and dissolvedoxygen concentration in water samples from five wells sampled monthly. 
detected in one sample at the detection limit of $1 \mu \mathrm{g} / \mathrm{L}$. NWQL analyzed two monthly samples from this well for VOC's and detected five constituents in one sample and six in the other. The largest concentration detected was $16 \mu \mathrm{g} / \mathrm{L}$ TCA, followed by $6.7 \mu \mathrm{g} / \mathrm{L} 1,1$-dichloroethane and $6.1 \mu \mathrm{g} / \mathrm{L}$ chloroform. PCE, 1,1-dichloroethylene, and carbon tetrachloride were also detected (table 12D).

\section{Agricultural Area}

Well S-51566 was sampled monthly from June 1987 through December 1988. Examination of the temporal changes at this well indicates low variability for all inorganic constituents and field characteristics except temperature, hardness, and calcium (figs. 4A, 4B, 4C). Temperature reached a minimum during January 1988 and a maximum during May 1988. Calcium concentrations and
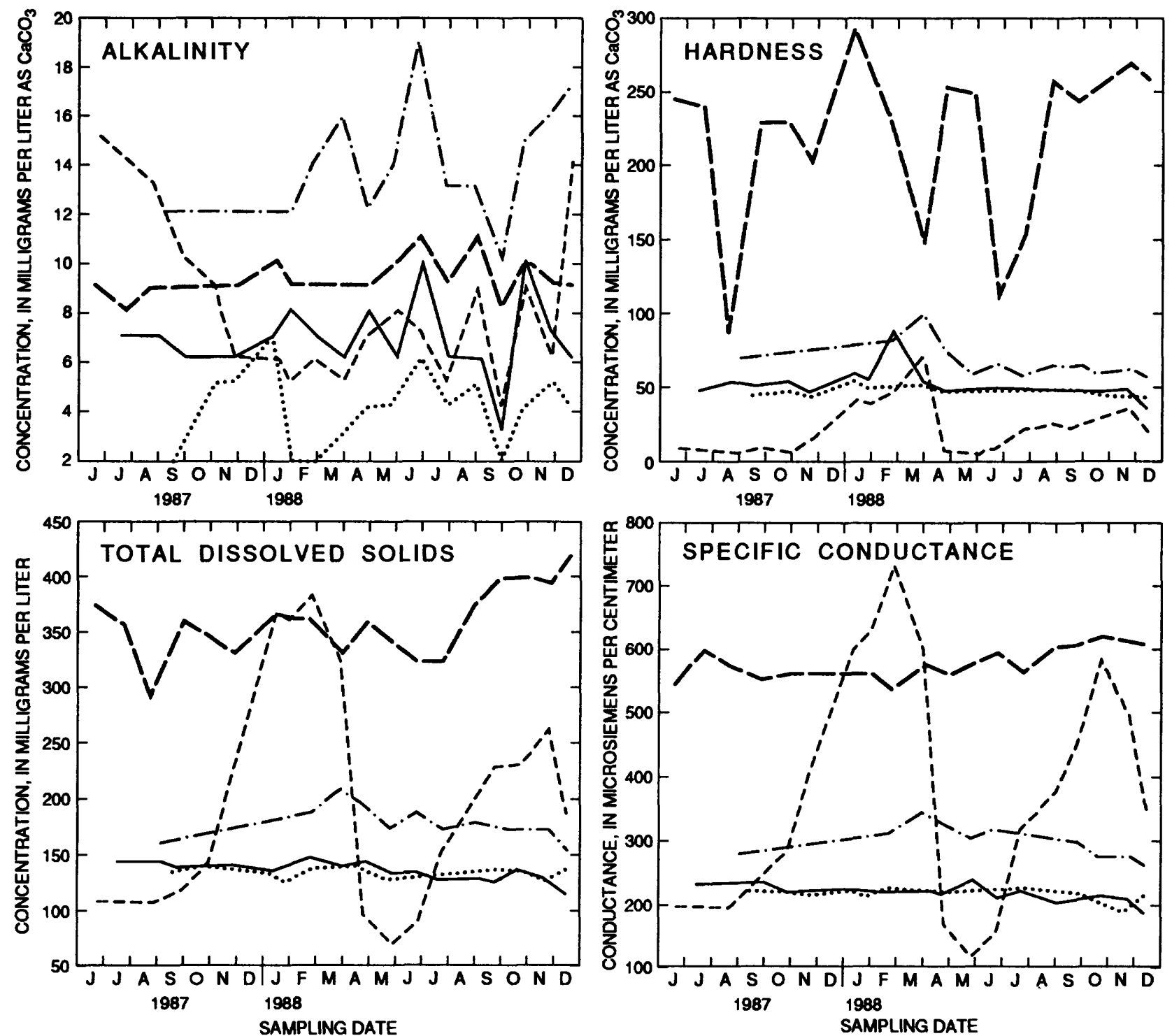

Figure 4B. Temporal variations in alkalinity, hardness, total dissolved solids, and specific conductance in water samples from five wells sampled monthly. 
hardness fluctuated widely; calcium concentrations ranged from 22.0 to 94.0 $\mathrm{mg} / \mathrm{L}$, and hardness ranged from 86 to $294 \mathrm{mg} / \mathrm{L}$ as $\mathrm{CaCO}_{3}$. Iron was detected in al1 19 samples; the maximum concentration was $1,120 \mu \mathrm{g} / \mathrm{L}$ (table 12B). VoC's were not detected (table 12C).

Organochlorine insecticides were detected in 13 of 17 samples (table 13A). DDT was detected at the detection limit $(0.01 \mu \mathrm{g} / \mathrm{L})$ in 11 samples, and DDE was detected at the detection limit $(0.01 \mu \mathrm{g} / \mathrm{L})$ in 7 samples. DDD and endosulfan were detected less frequently. Carbamate pesticides, primarily aldicarbsulfoxide and aldicarb sulfone, were detected in all samples from this well (table 13B). Maximum concentrations of these two constituents occurred during August 1987. Organophosphorus insecticides, chlorophenoxy-acid herbicides, and triazine herbicides were not detected (table 13C).
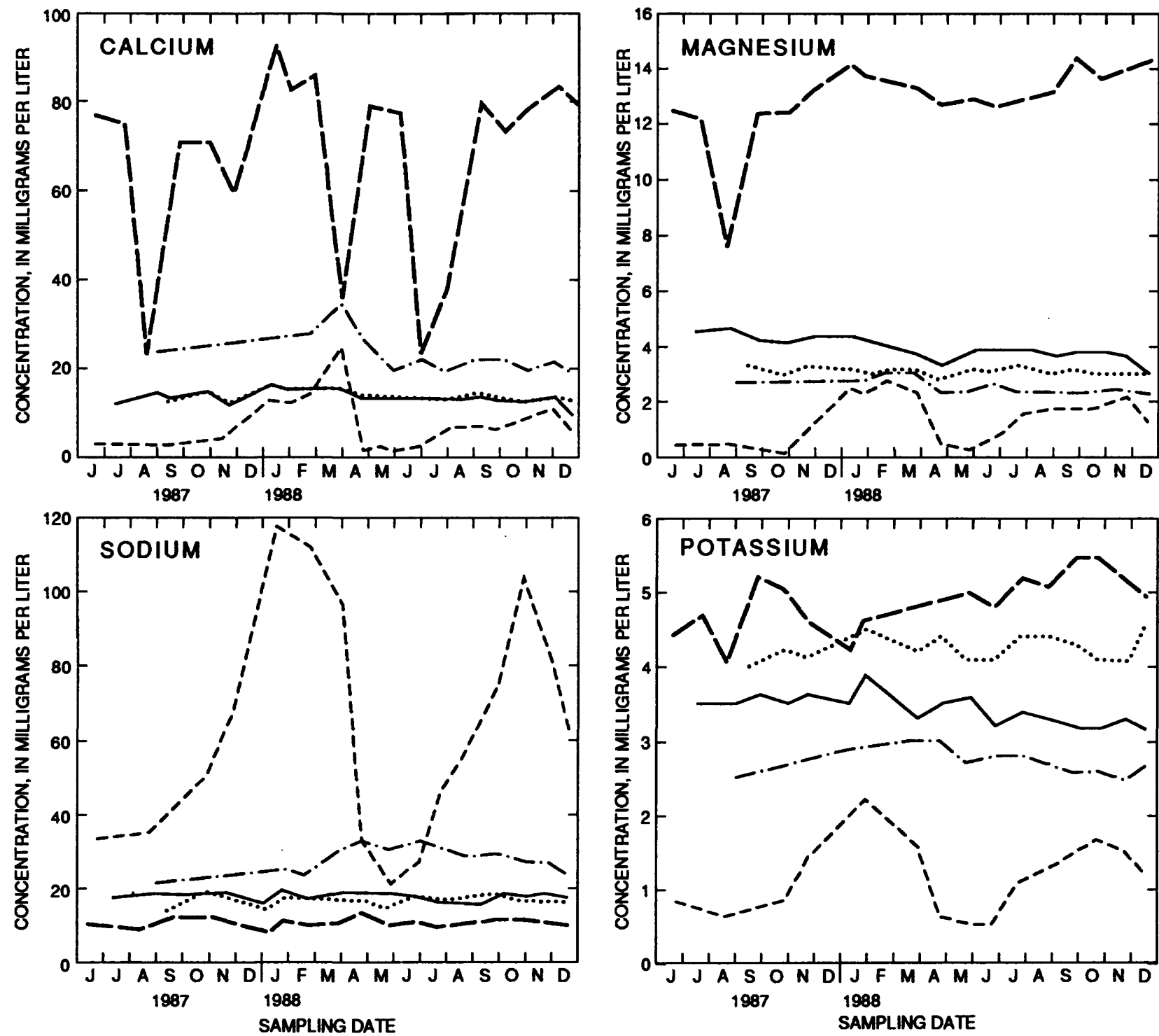

Figure 4C. Temporal variations in calcium, magnesium, sodium, and potassium in water samples from five wells sampled monthly. 
Well S-74294 was first sampled in June 1987, then monthly from August 1987 through December 1988. Temporal changes at this well indicate high variability of all constituents except magnesium, sulfate, and nitrate-nitrogen. Water temperature reached a minimum during January 1988. A distinct seasonal trend was observed for dissolved oxygen, specific conductance, total dissolved solids, sodium, and chloride; maximum values were measured during the winter, and minimum values during the summer. No trend was discernible for calcium or hardness; maximum values were measured in March 1988. Alkalinity ranged from 4 to $15 \mathrm{mg} / \mathrm{L}$, and $\mathrm{pH}$ from 5.14 to 6.14 . Iron was detected in 3 of the 18 samples from this well and had a maximum concentration of $310 \mu \mathrm{g} / \mathrm{L}$ ( $t a b l e$ 12B). Manganese was detected in 11 samples and had a maximum concentration of $150 \mu \mathrm{g} / \mathrm{L}$ (table 12B). Neither VOC's nor carbamate insecticides were detected in samples from this well (table 12C, 12D, and 13B).
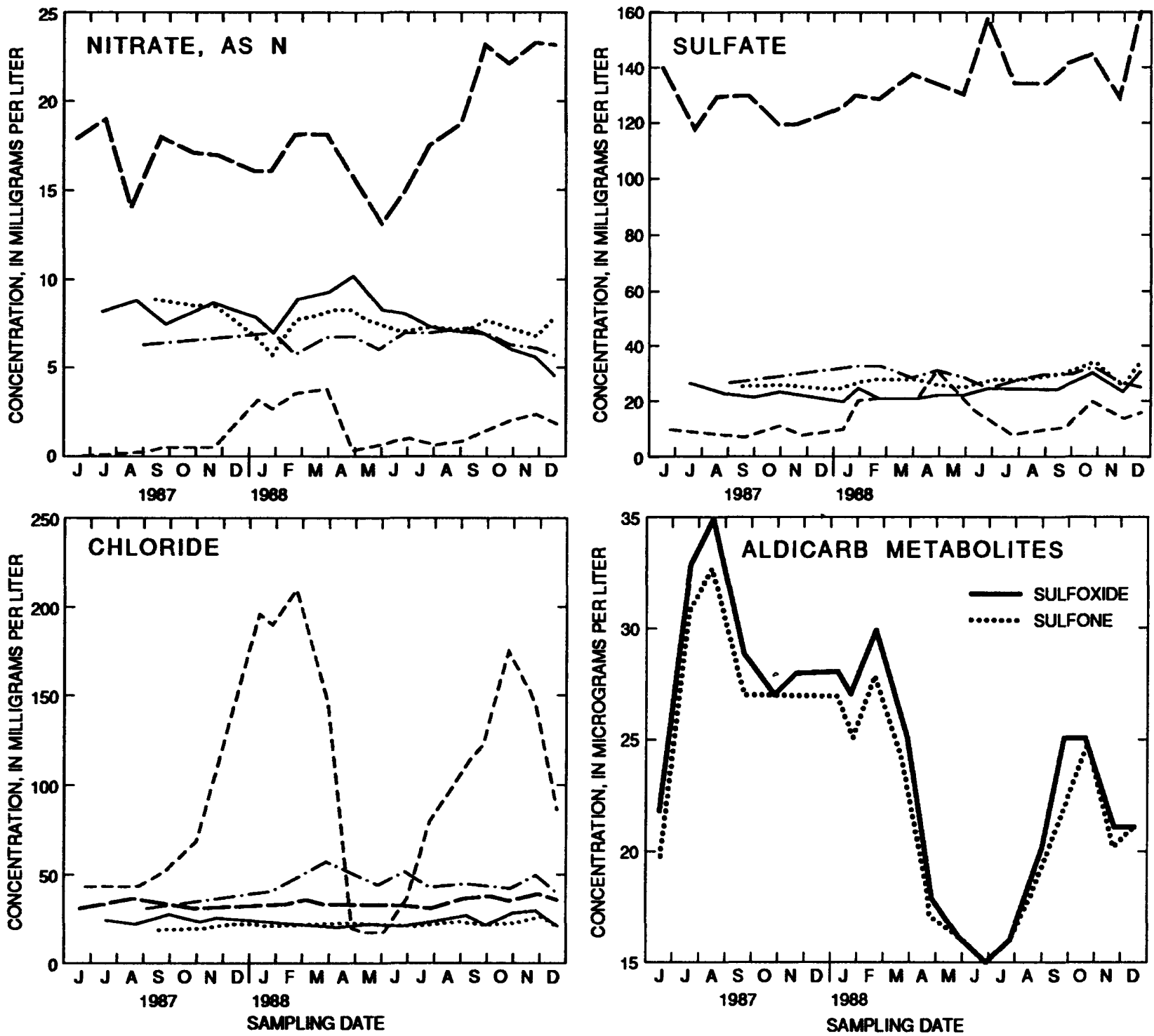

Figure 4D. Temporal variations in nitrate-nitrogen, sulfate, and chloride in water samples from five monthly wells, and aldicarb metabolites in water samples from the agricultural area's monthly well. 


\section{COMPARISONS AMONG THE FIVE STUDY AREAS}

This section discusses selected inorganic constituents and field characteristics, inorganic trace elements, VOC's, pesticides, and semivolatile organic compounds in samples from network wells and compares them among the study areas. Results for selected inorganic constituents and field characteristics are summarized and illustrated by box plots. Box plots summarize the data distributions by showing the median, interquartile range (25th to 75th percentile), and outlying values (fig. 5A). The Kruskal-Wallis test, a nonparametric version of a one-way analysis of variance, was used on ranked concentrations of inorganic constituents and field characteristics to determine significant differences between study areas. Tukey's Honest Significant Difference (HSD) Range Test was used to indicate which groups (study area) differ significantly (alpha $=0.05$ ) according to results from the Kruskal-Wallis test. These results are shown as boxed letters at the top of each box plot. Constituents with few detections above the detection limit, including most trace inorganic constituents, VOC's, and pesticides, are not easily illustrated by box plots; therefore the frequency of detections is used for comparison of these constituents among study areas. Pesticide results are arranged by pesticide groups for comparison and discussion.

\section{Major Inorganic lons and Field Characteristics}

As illustrated by Tukey's test results (fig. 5, p. 20-23), concentrations of potassium, nitrate-nitrogen, and total dissolved solids, and specific conductance values were significantly smaller in the undeveloped area than in the other four areas. Concentrations of calcium, sulfate, and potassium were significantly larger in the agricultural area than in the unsewered suburban area. Water temperatures were significantly higher in the two sewered suburban areas than in the other three areas and were significantly lower in the agricultural and undeveloped area were than in the other three areas. Dissolved oxygen concentrations were significantly larger in the undeveloped area than in the three suburban areas.

\section{Inorganic Trace Elements}

Results of analyses for inorganic trace elements are given in table 5 . The highest percentage of detections of iron and manganese was in samples from the agricultural area, followed by the recently sewered suburban area, the unsewered suburban area, the long-term sewered suburban area, and the undeveloped area, respectively. The highest iron concentration detected $(14,800 \mu \mathrm{g} / \mathrm{L})$ was in a sample from the long-term sewered suburban area and corresponded with a high manganese value of $2,750 \mu \mathrm{g} / \mathrm{L}$. The highest manganese concentration detected $(19,000 \mu \mathrm{g} / \mathrm{L})$ was in a sample from the recently sewered suburban area and corresponded with a high iron concentration of $5,550 \mu \mathrm{g} / \mathrm{L}$. The highest concentrations of iron and manganese in samples from the agricultural area were 4,900 and $1,500 \mu \mathrm{g} / \mathrm{L}$, respectively.

Boron was detected in samples from all five areas; the highest concentration $(360 \mu \mathrm{g} / \mathrm{L})$ was in a sample from the recently sewered suburban area. Tukey's test results show that the median concentration in samples from the agricultural area was significantly higher than in a sample from the unsewered suburban area and the undeveloped area (fig. 5D). Boron concentrations in the undeveloped area were significantly lower than in samples from the other four study areas. Other inorganic trace elements detected were barium, cadmium, chromium, copper, lead, and methylene blue active substances (table 5 ). 


\section{Volatile Organic Compounds}

Results of VOC analyses by the NCDH laboratory are shown in table 6; results of duplicate sample analysis by NWQL are given in tables 7A and 7B. VOC's were detected most commonly in samples from the recently sewered suburban area (14 out of 19 samples), followed by the long-term sewered suburban area (10 out of 20 samples), and the unsewered suburban area ( 8 out of 20 samples). VOC's were detected in 1 of the 15 samples from the undeveloped area, and in none of the 15 samples from the agricultural area.

The most commonly detected VOC's in samples from the three suburban study areas were TCA, TCE, and PCE. TCA was detected in 23 of 59 samples and was found most frequently in the recently sewered suburban area, where the highest concentration was $12,000 \mu \mathrm{g} / \mathrm{L}$. TCE was detected in 13 of 59 samples and was found most frequently in the recently sewered suburban area, where the highest concentration was $390 \mu \mathrm{g} / \mathrm{L}$. PCE was detected in 12 of 59 samples and was found most frequently in the recently sewered and long-term sewered suburban areas, where the highest concentration was $89 \mu \mathrm{g} / \mathrm{L}$ in the recently sewered suburban area.

Carbon tetrachloride and chlorobenzene were detected only in samples from the long-term sewered suburban area. Trans-1,2-dichloroethylene, 1,1,2trichloroethane, benzene, and xylene were detected only in samples from the recently sewered suburban area, and trichlorofluoromethane was detected only in samples from the unsewered suburban area.

Duplicate samples from 13 of the 90 wells were sent to NWQL for GC-MS analysis for VOC's; the most frequently detected VOC's were TCA and chloroform, followed by PCE and TCE. These results cannot be compared among study areas, but comparison with $\mathrm{NCDH}$ laboratory results provides information on detection levels for various constituents and quality-assurance information on the 13 samples on which duplicate analyses were done. NWQL results reveal three constituents at concentrations below NCDH laboratory detection limits and a higher frequency of detection in samples from 13 wells than was apparent in the NCDH laboratory results for the 89 wells. These three constituents are chloroform, 1,1-dichloroethane, and trans-1,2-dichloroethylene. Chloroform was detected in 3 of the 89 samples above the detection limit of $1 \mu \mathrm{g} / \mathrm{L}$ by $\mathrm{NCDH}$ laboratory, and in 10 of 13 samples above the detection limit of $0.2 \mu \mathrm{g} / \mathrm{L}$ by NWQL. Five of the 10 detections were at concentrations below the NCDH laboratory detection limit.

\section{Pesticides}

Organochlorine insecticides were detected most commonly in samples from the agricultural area (13 of 14 samples), followed by the recently sewered suburban area (16 of 20 samples), the long-term sewered suburban area (10 of 20 samples), the unsewered suburban area (4 of 20 samples), and the undeveloped area ( 1 of 15 samples). Dieldrin and heptachlor epoxide were detected in samples from the three suburban areas and the agricultural area; chlordane was detected only in samples from the three suburban areas. Endosulfan, DDD, DDE, lindane, methoxychlor, DDT, and perthane were detected only in samples from the agricultural area; one detection of endosulfan was reported for the undeveloped area. These results are summarized in table 8 .

Organophosphorus insecticides were detected in 2 of the 20 samples from the unsewered suburban area, in 1 of the 20 samples from the recently sewered suburban area, and in 1 of the 15 samples from the agricultural area. Neither 

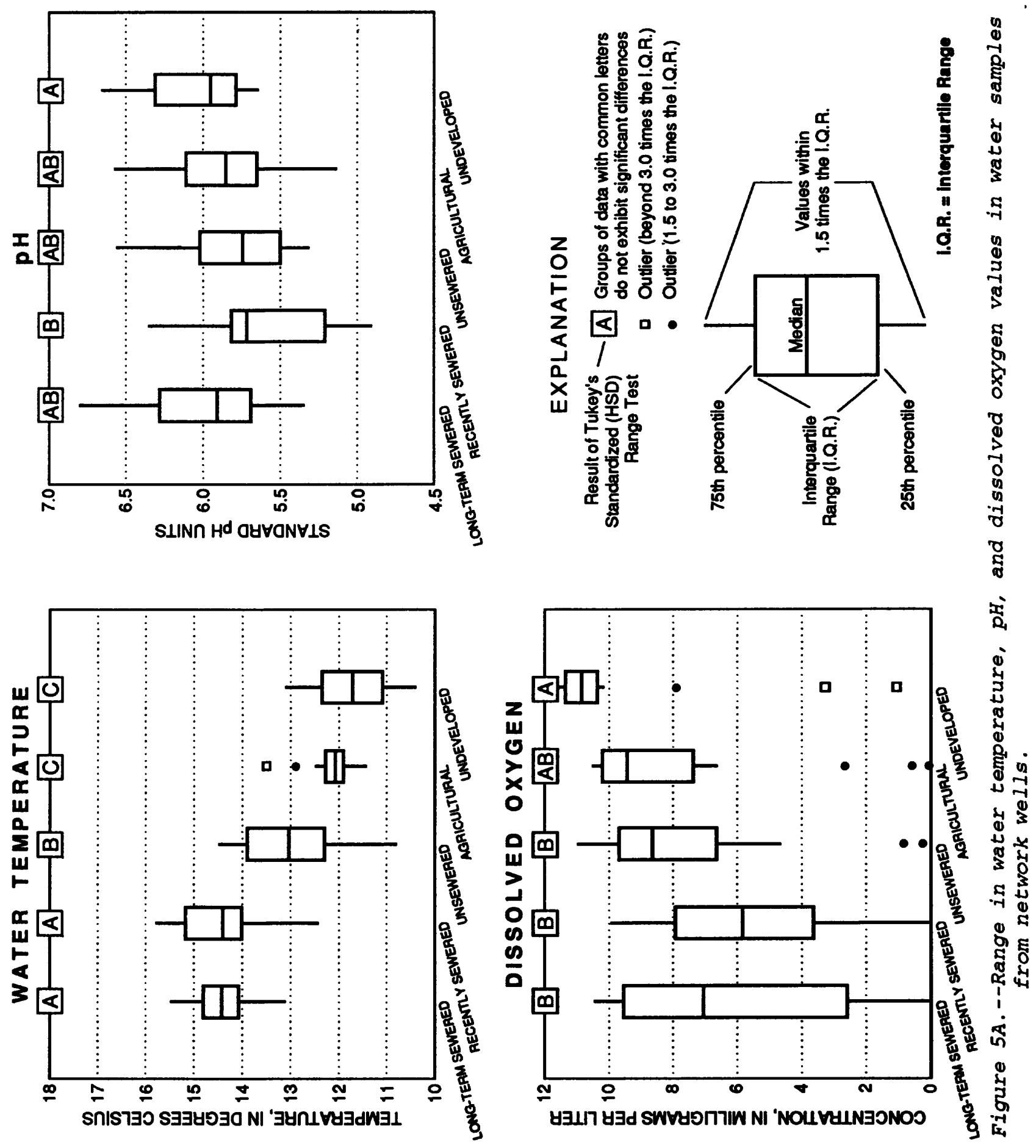

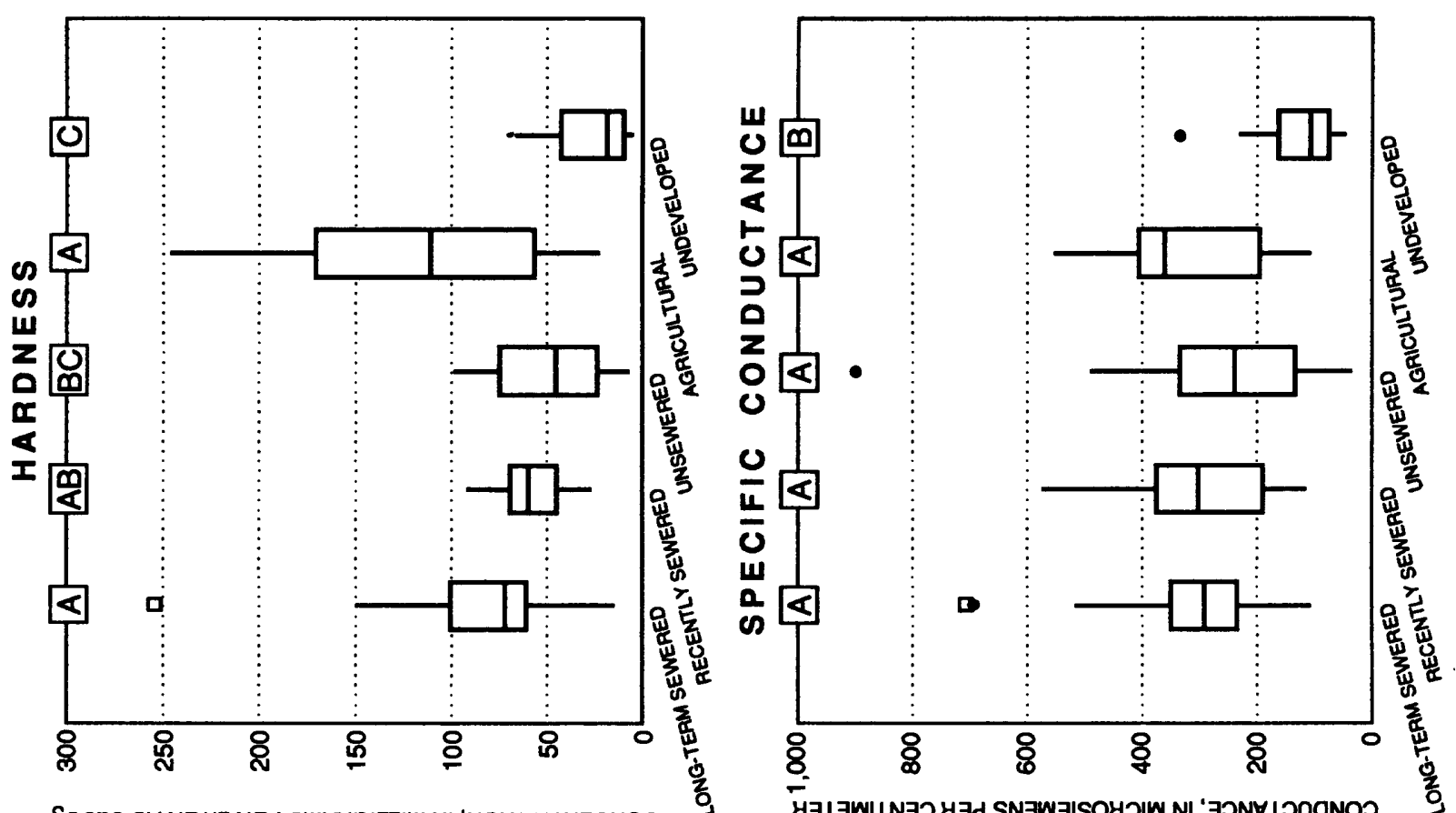

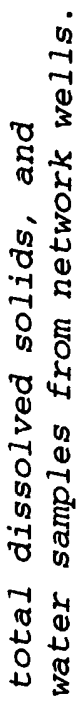

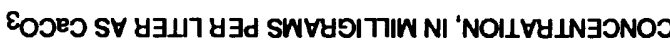

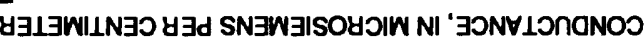

i่.

(⿻)

ชี

造

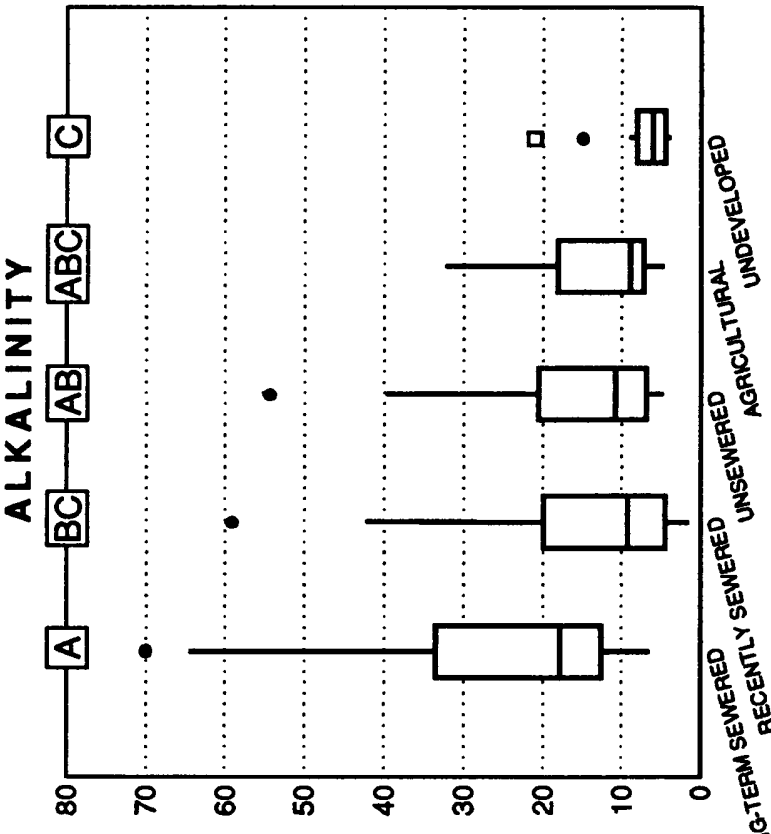

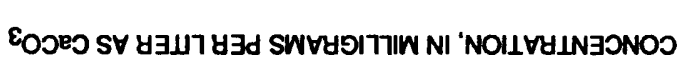

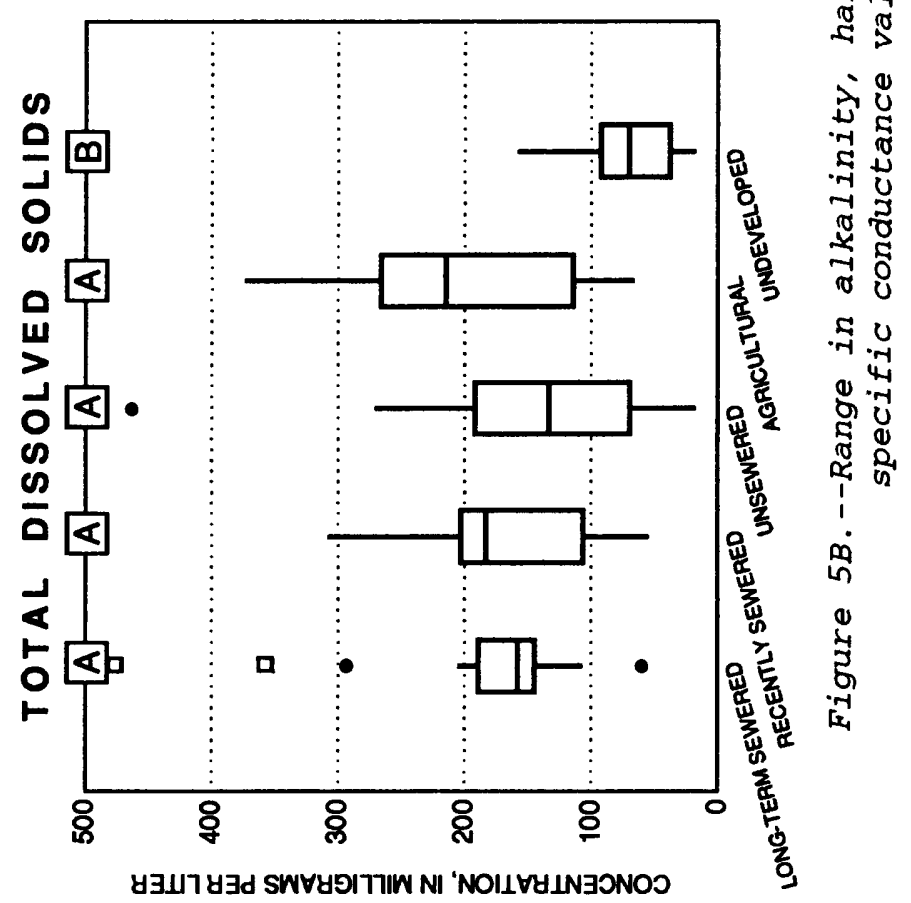



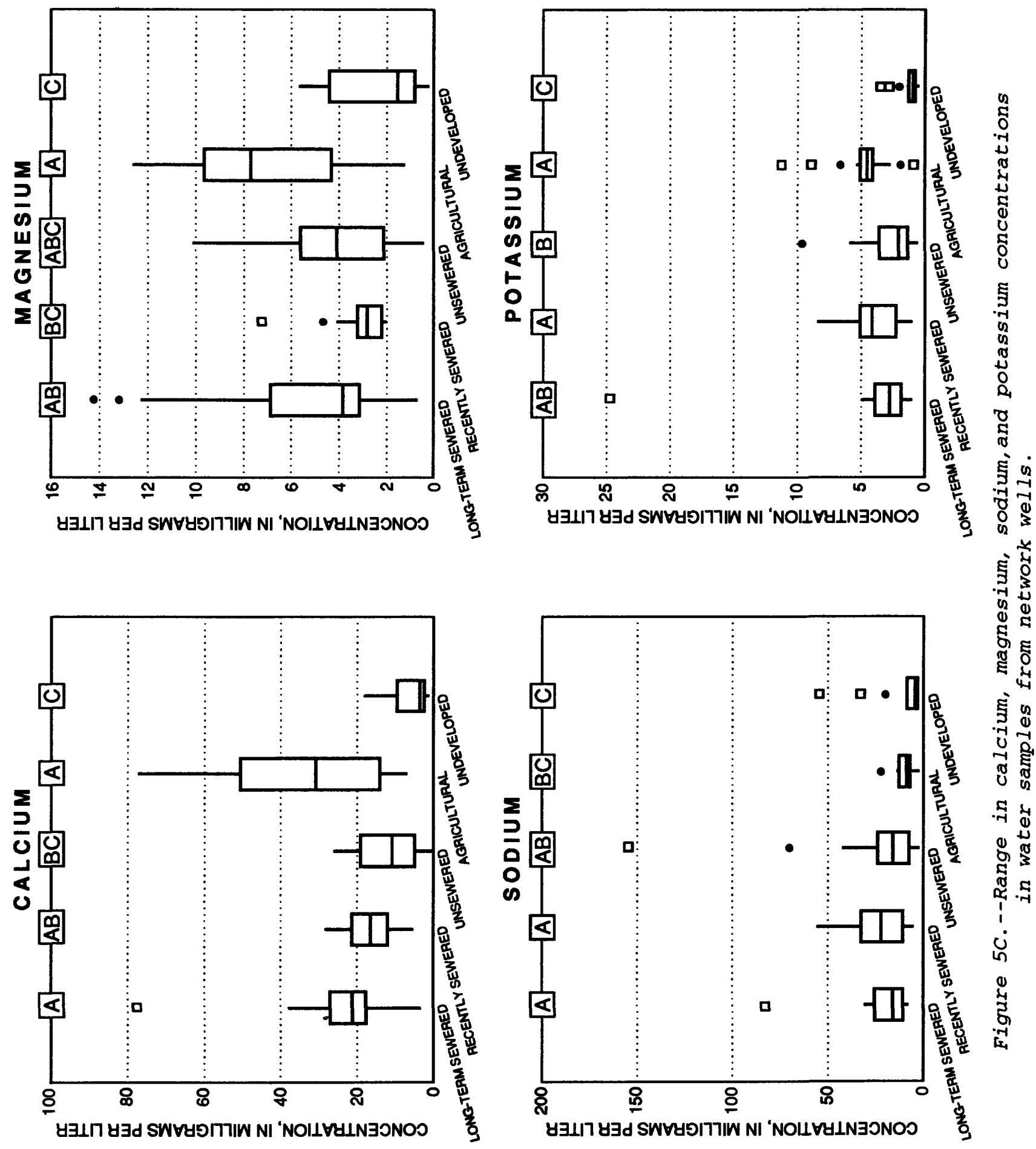

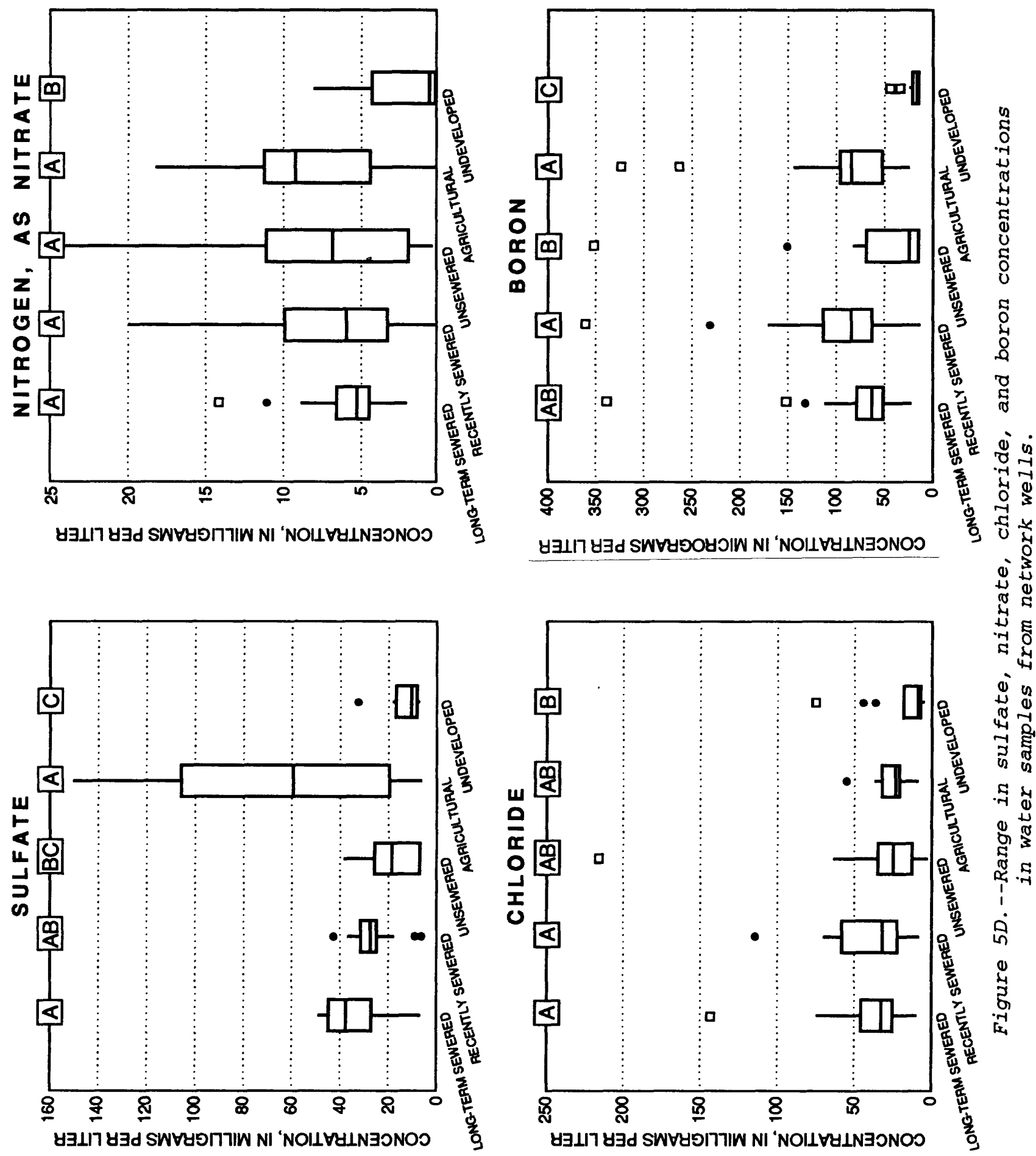
the long-term sewered suburban area nor the undeveloped area showed detection of these compounds. Results for these three groups of pesticides are given in tables $9 \mathrm{~A}$ and $9 \mathrm{~B}$.

Carbamate insecticides were detected primarily in the agricultural area and to a lesser extent in the undeveloped area and the unsewered suburban area. Concentrations of these insecticides were the highest of any pesticide in these areas. These compounds were not detected in the two sewered suburban areas (table 10).

Chlorophenoxy-acid herbicides were detected in 1 of 15 samples from the agricultural area and in 1 of 20 samples from each of the three suburban areas; none were detected in the undeveloped area. Triazine herbicides were detected in 5 of 20 samples from each of the two sewered suburban areas and in 3 of 20 samples from the unsewered suburban area. These compounds were not detected in the agricultural or undeveloped areas.

\section{Semivolatile Organic Compounds}

Methylene chloride-extractable compounds were detected in samples from 47 of the 90 wells by GC-FID scans. Twenty-five wells were resampled for GC-MS analysis by NWQL. Semivolatile organic compounds detected in these analyses are 1 isted in table 11A; those that were not detected are listed in table 11B. of the 25 wells resampled for GC-MS analysis, semivolatile organic compounds were detected in samples from five. Compounds detected were di-n-octyl phthalate, bis(2-ethylhexyl) phthalate, and naphthalene.

\section{SUMMARY}

This report presents chemical data on water samples collected from 90 water-table wells in five study areas as part of a project to statistically relate land use to water quality. The study areas, delineated according to predominant land use and sewering practices, are a long-term-sewered suburban area, a recently sewered suburban area, an unsewered suburban area, an agricultural area, and an undeveloped area. One well in each study area was sampled monthly for at least a year after the initial sampling to give information on temporal variability in water quality at each well. Chemical constituents analyzed for in each sample were inorganic constituents and field characteristics; volatile and semivolatile organic compounds; organochlorine, organophosphorus, and carbamate insecticides; and triazine and chlorophenoxyacid herbicides. Major results for each of the major constituent groups examined are presented below.

Inorganic constituents and field characteristics.--Median temperatures of samples from the two sewered suburban areas were significantly higher than those from the other three areas, and the median water temperature of samples from the unsewered suburban area was significantly higher than those of samples from the agricultural or undeveloped areas.

Specific conductance and concentrations of total dissolved solids, nitratenitrogen, and potassium were significantly lower in samples from the undeveloped area than in samples from the other four areas. Dissolved-oxygen concentrations were significantly higher in samples from the undeveloped area than in samples from the three suburban areas. Concentrations of calcium, sulfate, potassium, and boron were significantly higher in samples from the 
agricultural area than in samples from the undeveloped area and the unsewered suburban area. Iron and manganese were detected most commonly, and typically at elevated concentrations, in the agricultural area and the recently sewered suburban area.

Volatile organic compounds.--VOC's were detected primarily in the three suburban study areas. The recently sewered suburban area had detections in 14 out of 19 samples; the long-term sewered suburban area had detections in 10 out of 20 samples; and the unsewered suburban area had detections in 8 out of 20 samples. In these three areas combined, TCA was detected most commonly (23 of 59 samples), followed by TCE (13 of 59 samples), and PCE (12 of the 59 samples).

Semivolatile organic compounds.--GC-FID scans (a qualitative analysis that indicates the presence of groups of compounds within a range of concentrations) detected methylene chloride-extractable compounds (including semivolatile organic compounds) in 47 of the 90 samples. Quantitative analysis detected semivolatile organic compounds in 5 of the 25 wells that were resampled; the compounds detected were di-n-octylphthalate, bis(2ethylhexy 1) phthalate, and naphthalene.

Pesticides.--Insecticides were detected primarily in the suburban areas and the agricultural area. Organochlorine insecticides in the three suburban areas were dieldrin, heptachlor epoxide, and chlordane. In the agricultural area, heptachlor epoxide was detected most frequently, followed by dieldrin, endosulfan, and DDD. Organophosphorus insecticides were detected in the recently sewered suburban area, the unsewered suburban area, and the agricultural area. Carbamate insecticides were detected primarily in the agricultural area, where aldicarb sulfone, aldicarb sulfoxide, and carbofuran were detected at the highest concentrations of any pesticide. Chlorophenoxyacid herbicides were detected in one sample from each area except the undeveloped area, where none of these compounds were detected. The triazine herbicides simazine, atrazine, and prometone were detected in the three suburban areas, but no triazine herbicides were detected in the agricultural or undeveloped areas.

\section{REFERENCES CITED}

Brown, Eugene, Skougstad, M. W., and Fishman, M. J., 1970, Methods for collection and analysis of water samples for dissolved minerals and gases: U.S. Geological Survey Techniques for Water Resources Investigations, Book 5. Chapter A1, $160 \mathrm{p}$.

Doriski, T. P., and Wilde-Katz, Franceska, 1983, Geology of the "20-foot" clay and Gardiners clay in southern Nassau and southwestern Suffolk Counties, Long Island, New York: U.S. Geological Survey Water-Resources Investigations Report 82-4056, $17 \mathrm{p}$.

Eckhardt, D. A. V., Flipse, W. J., Jr., and Oaksford, E. T., 1989, Relation between land use and ground-water quality in the upper glacial aquifer in Nassau and Suffolk Counties, Long Island, New York: U.S. Geological Survey Water-Resources Investigations Report 86-4142, $35 \mathrm{p}$.

Franke, O. L., and Cohen, Philip, 1972, Regional rates of ground-water movement on Long Island, New York: U.S. Geological Survey Professional Paper 800-C, p. C271-C277. 


\section{REFERENCES CITED (continued)}

Helsel, D. R., and Ragone, S. E., 1984, Evaluation of regional ground-water quality in relation to land use--U.S. Geological Survey toxic waste groundwater contamination program: U.S. Geological Survey Water Resources Investigations Report 84-4217, $33 \mathrm{p}$.

Long Island Regional Planning Board, 1982a, Quantification and analysis of land use for Nassau and Suffolk Counties, 1981: Hauppauge, N.Y., 47 p. 1982b, Historical population of Long Island communities 1790-1980: Hauppauge, N.Y., 77 p.

Lubke, E.R., 1964, Hydrogeology of the Huntington-Smithtown Area Suffolk County, New York: U.S. Geological Survey Water Supply Paper 1669-D.

McClymonds, N.E., and Franke, O. L., 1972, Water-transmitting properties of aquifers on Long Island, New York: U.S. Geological Survey Professional Paper 627-E, $24 \mathrm{p}$.

Soren, J., and Simmons, D.L., 1987, Thickness and hydrogeology of aquifers and confining units below the upper glacial aquifers on Long Island, New York, Water Resources Investigations Report 86-4175, 3 sheets, scale 1:125,000.

U.S. Bureau of the Census, 1985, Technical documentation: Population (1984) and per capita income (1983) estimates: Washington, D.C. Governmental Units, $6 \mathrm{p}$. 
Table 1.--Types of land use within the five study areas

[Values are in percent. Data from Long Island Regional Planning Board, 1982a. Locations are shown in fig. $1 . \mathrm{mi}^{2}=$ square miles]

\begin{tabular}{|c|c|c|c|c|c|}
\hline \multirow[b]{2}{*}{ Type of land use } & \multicolumn{5}{|c|}{ Classification and size of study area } \\
\hline & $\begin{array}{l}\text { Long-term } \\
\text { sewered } \\
\text { suburban } \\
\left(33.5 \mathrm{mi}^{2}\right) \\
\end{array}$ & $\begin{array}{c}\text { Recently } \\
\text { sewered } \\
\text { suburban } \\
\left(30.2 \mathrm{mi}^{2}\right) \\
\end{array}$ & $\begin{array}{l}\text { Unsewered } \\
\text { suburban } \\
\left(58.8 \mathrm{mi}^{2}\right)\end{array}$ & $\begin{array}{c}\text { Agri- } \\
\text { cultural } \\
\left(41.2 \mathrm{mi}^{2}\right) \\
\end{array}$ & $\begin{array}{c}\text { Undeveloped } \\
\left(48.9 \mathrm{mi}^{2}\right) \\
\end{array}$ \\
\hline \multicolumn{6}{|l|}{ Residential } \\
\hline \multicolumn{6}{|l|}{$\begin{array}{l}\text { Number of } \\
\text { dwelling units } \\
\text { per acre: }\end{array}$} \\
\hline 1 & 3 & 3 & 19 & 3 & 3 \\
\hline 2 to 4 & 6 & 1 & 33 & 5 & 2 \\
\hline 5 to 10 & 49 & 57 & 0 & 1 & 0 \\
\hline 11 or more & 2 & 1 & 0 & 1 & 1 \\
\hline Commercial & 13 & 7 & 3 & 2 & 0 \\
\hline Industrial & 4 & 7 & 3 & 1 & 0 \\
\hline Institutional & 9 & 6 & 9 & 1 & 2 \\
\hline $\begin{array}{l}\text { Open spacel } \\
\text { recreational }\end{array}$ & 10 & 11 & 10 & 3 & 12 \\
\hline Agricultural & 0 & 0 & 4 & 58 & 8 \\
\hline $\begin{array}{l}\text { Utilities/ } \\
\text { transporation }\end{array}$ & 3 & 6 & 7 & 3 & 10 \\
\hline Vacant & 3 & 2 & 10 & 21 & 62 \\
\hline
\end{tabular}

Table 2.--Well-construction data on network wells and hydrogeologic characteristics at time of sampling

[Al] measurements are in feet. UPGL, upper glacial aquifer; MGTY, Magothy aquifer; SDBWT, screen depth below water table; - , no data]

\begin{tabular}{|c|c|c|c|c|c|c|c|c|c|c|}
\hline \multirow{2}{*}{$\begin{array}{l}\text { Well } \\
\text { number }\end{array}$} & \multirow{2}{*}{$\begin{array}{c}\text { Date } \\
\text { sampled }\end{array}$} & \multirow[b]{2}{*}{ Aquifer } & \multirow[b]{2}{*}{ Latitude } & \multirow[b]{2}{*}{ Longitude } & \multirow[b]{2}{*}{ Altitude } & \multirow{2}{*}{$\begin{array}{r}\text { Well } \\
\text { depth }\end{array}$} & \multicolumn{2}{|c|}{ Screen depth } & \multirow{2}{*}{$\begin{array}{c}\text { Depth } \\
\text { to } \\
\text { water }\end{array}$} & \multirow[b]{2}{*}{ SDBWT } \\
\hline & & & & & & & Top & Bottom & & \\
\hline & & & LONG - T & RM SEWERED & SUBURBAN $F$ & REA & & & & \\
\hline N 9057 & $10-22-87$ & UPGL & 404242 & 733422 & 70.24 & 47 & 42 & 47 & 25.4 & 19 \\
\hline N 9803 & $10-01-87$ & MGTY & 404330 & 733530 & 82.37 & 62 & 54 & 59 & 29.7 & 27 \\
\hline N 9914 & $09-08-87$ & UPGL & 404409 & 733741 & 99.56 & 57 & 49 & 54 & 44.9 & 7 \\
\hline N 9940 & $08-31-87$ & UPGL & 404523 & 733634 & 107.05 & 53 & 45 & 50 & 42.4 & 5 \\
\hline N 9941 & $08-31-87$ & UPGL & 404443 & 733625 & 86.51 & 50 & 42 & 47 & 25.3 & 19 \\
\hline
\end{tabular}


Table 2.--Well-construction data on network wells and hydrogeologic characteristics at time of sampling (continued)

\begin{tabular}{lcccc}
\hline & & & & Depth \\
Weli & Date & & Well Screen depth & to \\
number & sampled & Aquifer Latitude Longitude Altitude depth Top Bottom water sDBWT \\
\hline
\end{tabular}

LONG-TERM SEWERED SUBURBAN AREA (continued)

\begin{tabular}{|c|c|c|c|c|c|c|c|c|c|c|c|}
\hline $\mathbf{N}$ & 9942 & $09-08-87$ & UPGL & 404455 & 733814 & 112.82 & 69 & 61 & 66 & 53.5 & 10 \\
\hline $\mathrm{N}$ & 9943 & $09-15-87$ & UPGL & 404342 & 733805 & 90.91 & 69 & 61 & 66 & 42.5 & 21 \\
\hline $\mathrm{N}$ & 9944 & $09-10-87$ & UPGL & 404410 & 734004 & 96.01 & 80 & 72 & 77 & 49.6 & 25 \\
\hline $\mathrm{N}$ & 9945 & $09-09-87$ & UPGL & 404253 & 733956 & 75.72 & 67 & 59 & 64 & 39.0 & 22 \\
\hline $\mathrm{N}$ & 9946 & $09-09-87$ & UPGL & 404531 & 733935 & 106.19 & 60 & 52 & 57 & 50.1 & 4 \\
\hline $\mathrm{N}$ & 9947 & $10-06-87$ & UPGL & 404319 & 734329 & 81.22 & 109 & 101 & 106 & 59.9 & 44 \\
\hline $\mathrm{N}$ & 9948 & $09-03-87$ & MGTY & 404508 & 734056 & 124.83 & 114 & 106 & 111 & 81.3 & 27 \\
\hline $\mathrm{N}$ & 9949 & $09-10-87$ & UPGL & 404416 & 734058 & 106.90 & 100 & 91 & 96 & 64.8 & 29 \\
\hline $\mathrm{N}$ & 9959 & $10-06-87$ & UPGL & 404412 & 733634 & 81.38 & 54 & 48 & 54 & 23.4 & 28 \\
\hline $\mathrm{N}$ & 9962 & $10-13-87$ & UPGL & 404446 & 733724 & 110.86 & 65 & 60 & 65 & 50.4 & 12 \\
\hline $\mathrm{N}$ & 9979 & $10-22-87$ & UPGL & 404232 & 734325 & 70.64 & 95 & 87 & 92 & 54.6 & 35 \\
\hline $\mathrm{N}$ & 9982 & $09-03-87$ & MGTY & 404435 & 734202 & 120.07 & 112 & 104 & 109 & 80.2 & 26 \\
\hline $\mathrm{N}$ & 9983 & $09-02-87$ & MGTY & 404404 & 734202 & 107.39 & 99 & 91 & 96 & 69.6 & 24 \\
\hline $\mathrm{N}$ & 9984 & $09-02-87$ & UPGL & 404251 & 734046 & 78.00 & 60 & 51 & 56 & 45.8 & 8 \\
\hline $\mathrm{N}$ & 10035 & $10-01-87$ & UPGL & 404338 & 733715 & 77.22 & 56 & 48 & 53 & 28.2 & 22 \\
\hline
\end{tabular}

RECENTLY SEWERED SUBURBAN AREA

\begin{tabular}{|c|c|c|c|c|c|c|c|c|c|c|}
\hline $\mathrm{N}$ & 1197 & $10-13-87$ & UPGL & 404453 & 733239 & 116.05 & 69 & 64 & 69 & 49.3 \\
\hline $\mathrm{N}$ & 8888 & $09-28-87$ & UPGL & 404703 & 733056 & 174.49 & 111 & 106 & 111 & 94.4 \\
\hline$N$ & 8984 & $10-19-87$ & UPGL & 404452 & 733446 & 104.00 & 52 & 47 & 52 & 36.2 \\
\hline $\mathrm{N}$ & 9078 & $10-05-87$ & UPGL & 404324 & 733422 & 83.62 & 65 & 60 & 65 & 31.3 \\
\hline $\mathrm{N}$ & 9079 & $10-07-87$ & UPGL & 404508 & 733024 & 118.85 & 70 & 65 & 70 & 52.3 \\
\hline $\mathrm{N}$ & 9222 & $10-14-87$ & UPGL & 404351 & 733327 & 92.53 & 46 & 40 & 45 & 35.9 \\
\hline $\mathrm{N}$ & 9354 & $10-05-87$ & UPGL & 404539 & 733501 & 117.97 & 89 & 84 & 89 & 47.1 \\
\hline $\mathbf{N}$ & 9451 & $10-14-87$ & UPGL & 404414 & 733253 & 97.48 & 42 & 36 & 41 & 36.8 \\
\hline $\mathrm{N}$ & 9917 & $09-17-87$ & UPGL & 404524 & 733251 & 124.79 & 76 & 68 & 73 & 53.4 \\
\hline $\mathrm{N}$ & 9918 & $09-21-87$ & MGTY & 404435 & 733057 & 111.70 & 77 & 70 & 75 & 48.3 \\
\hline $\mathrm{N}$ & 9919 & $09-17-87$ & UPGL & 404535 & 733146 & 136.27 & 84 & 76 & 81 & 64.5 \\
\hline $\mathrm{N}$ & 9920 & $09-21-87$ & MGTY & 404607 & 733021 & 145.95 & 89 & 81 & 86 & 71.5 \\
\hline $\mathrm{N}$ & 9924 & $09-29-87$ & UPGL & 404320 & 733056 & 77.10 & 45 & 37 & 42 & 27.6 \\
\hline $\mathrm{N}$ & 9925 & $09-23-87$ & UPGL & 404325 & 733220 & 86.03 & 51 & 44 & 49 & 34.1 \\
\hline $\mathrm{N}$ & 9926 & $09-23-87$ & MGTY & 404718 & 733150 & 168.18 & 130 & 122 & 127 & 87.2 \\
\hline $\mathrm{N}$ & 9927 & $09-22-87$ & UPGL & 404631 & 733118 & 161.68 & 94 & 86 & 91 & 85.1 \\
\hline $\mathrm{N}$ & 9928 & $09-22-87$ & UPGL & 404624 & 733215 & 145.21 & 86 & 77 & 82 & 67.1 \\
\hline $\mathrm{N}$ & 9933 & $09-29-87$ & MGTY & 404718 & 733000 & 178.97 & 115 & 106 & 111 & 98.2 \\
\hline $\mathrm{N}$ & 9938 & $09-16-87$ & UPGL & 404526 & 733335 & 124.40 & 80 & 72 & 77 & 53.5 \\
\hline $\mathrm{N}$ & 9939 & $09-16-87$ & UPGL & 404435 & 733343 & 105.05 & 74 & 66 & 71 & 41.2 \\
\hline
\end{tabular}

UNSEWERED SUBURBAN AREA

\begin{tabular}{|c|c|c|c|c|c|c|c|c|c|}
\hline S 24771 & $07-27-87$ & UPGL & 404820 & 731603 & 141.08 & 127 & 117 & 127 & 86.5 \\
\hline S 29778 & $07-27-87$ & MGTY & 404710 & 732640 & 195.17 & 168 & 158 & 168 & 120.0 \\
\hline S 45207 & $08-04-87$ & UPGL & 405132 & 731814 & 163.42 & 146 & 134 & 144 & 102.3 \\
\hline S 45208 & $07-09-87$ & UPGL & 405005 & 732337 & 183.45 & 137 & 123 & 133 & 107.5 \\
\hline S 45210 & $07-07-87$ & UPGL & 404945 & 731745 & 128.27 & 109 & 97 & 107 & 67.4 \\
\hline
\end{tabular}


Table 2.--Well-construction data on network wells and hydrogeologic characteristics at time of sampling (continued)

\begin{tabular}{|c|c|c|c|c|c|c|c|c|c|c|}
\hline \multirow{2}{*}{$\begin{array}{l}\text { Well } \\
\text { number }\end{array}$} & \multirow{2}{*}{$\begin{array}{c}\text { Date } \\
\text { sampled. }\end{array}$} & \multirow[b]{2}{*}{ Aquifer } & \multirow[b]{2}{*}{ Lat1tude } & \multirow[b]{2}{*}{ Long1tude } & \multirow[b]{2}{*}{ Altitude } & \multirow{2}{*}{$\begin{array}{l}\text { Well } \\
\text { depth }\end{array}$} & \multicolumn{2}{|c|}{ Screen depth } & \multirow{2}{*}{$\begin{array}{c}\text { Depth } \\
\text { to } \\
\text { water }\end{array}$} & \multirow[b]{2}{*}{ SDBV } \\
\hline & & & & & & & Top & Bottom & & \\
\hline & & & UNSEWEF & SUBURBAN & AREA ( & ined) & & & & \\
\hline $\begin{array}{ll}\text { S } & 45594 \\
\text { S } & 46283 \\
\text { S } & 47220 \\
\text { S } & 48375 \\
\text { S } & 50513\end{array}$ & $\begin{array}{l}08-13-87 \\
07-21-87 \\
07-09-87 \\
07-22-87 \\
07-16-87\end{array}$ & $\begin{array}{l}\text { UPGL } \\
\text { UPGL } \\
\text { UPGL } \\
\text { UPGL } \\
\text { UPGL }\end{array}$ & $\begin{array}{l}404920 \\
404823 \\
404759 \\
404755 \\
405100\end{array}$ & $\begin{array}{l}731509 \\
732118 \\
732516 \\
732442 \\
731526\end{array}$ & $\begin{array}{r}102.37 \\
273.09 \\
175.32 \\
136.40 \\
92.94\end{array}$ & $\begin{array}{r}85 \\
239 \\
92 \\
79 \\
61\end{array}$ & $\begin{array}{r}73 \\
225 \\
79 \\
64 \\
57\end{array}$ & $\begin{array}{r}83 \\
235 \\
89 \\
69 \\
61\end{array}$ & $\begin{array}{c}54.1 \\
204.0 \\
67.0 \\
60.1 \\
47.3\end{array}$ & $\begin{array}{r}24 \\
26 \\
17 \\
6 \\
12\end{array}$ \\
\hline $\begin{array}{ll}S & 64313 \\
S & 64314 \\
S & 64316 \\
S & 64318 \\
S & 64319\end{array}$ & $\begin{array}{l}08-05-87 \\
08-05-87 \\
07-15-87 \\
07-13-87 \\
07-28-87\end{array}$ & $\begin{array}{l}\text { UPGL } \\
\text { UPGL } \\
\text { UPGL } \\
\text { UPGL } \\
\text { UPGL }\end{array}$ & $\begin{array}{l}404659 \\
404818 \\
404746 \\
404737 \\
404623\end{array}$ & $\begin{array}{l}732020 \\
731716 \\
732219 \\
732516 \\
732539\end{array}$ & $\begin{array}{r}89.20 \\
99.94 \\
159.91 \\
-- \\
110.00\end{array}$ & $\begin{array}{l}30 \\
60 \\
63 \\
60 \\
45\end{array}$ & $\begin{array}{l}25 \\
55 \\
58 \\
55 \\
40\end{array}$ & $\begin{array}{l}30 \\
60 \\
63 \\
60 \\
45\end{array}$ & $\begin{array}{l}19.7 \\
42.5 \\
50.6 \\
43.6 \\
38.1\end{array}$ & $\begin{array}{r}8 \\
15 \\
10 \\
14 \\
4\end{array}$ \\
\hline $\begin{array}{ll}S & 65602 \\
S & 65607 \\
S & 68762 \\
S & 74286 \\
S & 75456\end{array}$ & $\begin{array}{l}07-15-87 \\
07-16-87 \\
08-06-87 \\
07-21-87 \\
07-27-87\end{array}$ & $\begin{array}{l}\text { UPGL } \\
\text { UPGL } \\
\text { UPGL } \\
\text { MGTY } \\
\text { UPGL }\end{array}$ & $\begin{array}{l}405030 \\
405003 \\
404932 \\
404750 \\
404859\end{array}$ & $\begin{array}{l}731806 \\
731552 \\
732437 \\
732253 \\
731940\end{array}$ & $\begin{array}{l}145.81 \\
137.72 \\
158.50 \\
154.07 \\
229.52\end{array}$ & $\begin{array}{r}96 \\
102 \\
86 \\
115 \\
203\end{array}$ & $\begin{array}{r}91 \\
97 \\
79 \\
107 \\
195\end{array}$ & $\begin{array}{r}96 \\
102 \\
84 \\
112 \\
200\end{array}$ & $\begin{array}{c}74.5 \\
88.1 \\
67.0 \\
81.2 \\
156.8\end{array}$ & $\begin{array}{l}19 \\
11 \\
14 \\
28 \\
41\end{array}$ \\
\hline
\end{tabular}

$\begin{array}{ll}\text { S } & 51566 \\ \text { S } & 51567 \\ \text { S } & 51568 \\ \text { S } & 51571 \\ \text { S } & 51572 \\ \text { S } & 51575 \\ \text { S } & 51576 \\ \text { S } & 51577 \\ \text { S } & 51578 \\ \text { S } & 51581 \\ \text { S } & 51582 \\ \text { S } & 51587 \\ \text { S } & 51588 \\ \text { S } & 51589 \\ \text { S } & 52383\end{array}$

$\begin{array}{ll}06-17-87 & \text { UPGL } \\ 06-16-87 & \text { UPGL } \\ 06-10-87 & \text { UPGL } \\ 08-18-87 & \text { UPGL } \\ 06-11-87 & \text { UPGL } \\ 06-17-87 & \text { UPGL } \\ 06-17-87 & \text { UPGL } \\ 06-10-87 & \text { UPGL } \\ 07-29-87 & \text { UPGL } \\ 08-17-87 & \text { UPGL } \\ 07-29-87 & \text { UPGL } \\ 06-09-87 & \text { UPGL } \\ 06-16-87 & \text { UPGL } \\ 06-18-87 & \text { UPGL } \\ 06-22-87 & \text { UPGL }\end{array}$

\section{AGRICULTURAI AREA}

$\begin{array}{rrrrrrrr}405716 & 724133 & 72.34 & 89 & 76 & 86 & 58.0 & 23 \\ 405653 & 724225 & 79.73 & 92 & 79 & 89 & 63.8 & 20 \\ 405808 & 723854 & 54.08 & 70 & 58 & 68 & 44.2 & 19 \\ 405805 & 724037 & 86.25 & 108 & 95 & 105 & 78.6 & 21 \\ 405651 & 723929 & 32.58 & 43 & 31 & 41 & 18.8 & 17 \\ 405544 & 724118 & 24.71 & 34 & 22 & 32 & 6.8 & 20 \\ 405559 & 724252 & 57.99 & 69 & 56 & 66 & 39.0 & 22 \\ 405630 & 724420 & 80.38 & 95 & 83 & 93 & 62.0 & 26 \\ 405721 & 724537 & 109.40 & 126 & 114 & 124 & 97.1 & 22 \\ 405722 & 723420 & 27.43 & 45 & 32 & 42 & 20.5 & 17 \\ 405853 & 723539 & 61.08 & 84 & 72 & 82 & 53.9 & 23 \\ 405809 & 723709 & 57.32 & 80 & 66 & 76 & 46.7 & 25 \\ 405634 & 723805 & 34.61 & 60 & 47 & 57 & 24.8 & 27 \\ 405701 & 723610 & 24.85 & 43 & 30 & 40 & 16.2 & 19 \\ 405542 & 724453 & 59.85 & 64 & 51 & 61 & 36.1 & 19\end{array}$

\section{UNDEVELOPED AREA}

\begin{tabular}{rlllllrrrrr} 
S 34742 & $06-30-87$ & UPGL & 405038 & 724147 & 67.56 & 97 & 82 & 92 & 46.5 & 40 \\
S 46544 & $07-06-87$ & UPGL & 405139 & 724324 & 102.71 & 107 & 103 & 107 & 77.2 & 28 \\
S 47755 & $06-23-87$ & UPGL & 405136 & 724645 & 59.74 & 58 & 45 & 55 & 28.6 & 21 \\
S 48584 & $06-24-87$ & UPGL & 405139 & 723850 & 86.37 & 89 & 75 & 86 & 66.8 & 14 \\
S 48946 & $06-30-87$ & UPGL & 405121 & 724906 & 45.00 & 45 & 31 & 41 & 10.8 & 25 \\
S 54886 & $06-29-87$ & UPGL & 405241 & 723818 & 59.04 & 55 & 51 & 55 & 41.0 & 12 \\
S 73807 & $07-01-87$ & UPGL & 405102 & 724506 & 108.75 & 100 & 95 & 98 & 84.0 & 12 \\
S 73811 & $06-29-87$ & UPGL & 405014 & 724657 & 83.47 & 85 & 80 & 85 & 57.0 & 26 \\
S 74293 & $06-25-87$ & UPGL & 405017 & 724950 & 83.37 & 71 & 67 & 71 & 53.6 & 15 \\
S 74294 & $06-24-87$ & UPGL & 405213 & 724808 & 57.58 & 36 & 32 & 36 & 21.6 & 12 \\
S 74295 & $06-29-87$ & UPGL & 405046 & 724727 & 68.90 & 56 & 52 & 56 & 39.8 & 14 \\
S 74301 & $07-01-87$ & UPGL & 405330 & 724438 & 107.32 & 109 & 105 & 109 & 70.0 & 37 \\
S 74307 & $07-02-87$ & UPGL & 405131 & 724030 & 89.52 & 86 & 82 & 86 & 59.9 & 24 \\
S 86583 & $07-30-87$ & UPGL & 405106 & 725009 & --5 & 41 & 36 & 41 & 18.3 & 20 \\
S 86584 & $07-30-87$ & UPGL & 404949 & 725039 & 51.15 & 46 & 41 & 46 & 24.6 & 19 \\
\hline
\end{tabular}


Table 3.--Inorganic and organic chemical constituents for which water samples were analyzed

[NWQL = National Water Quality Laboratory, NCDH $=$ Nassau County Department of Health Laboratory]

Inorganic-chemical constituents analyzed by NCDH

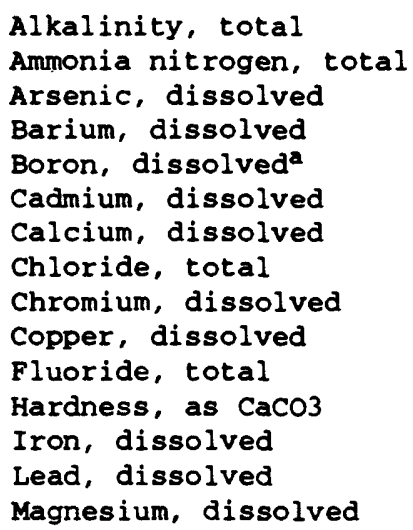

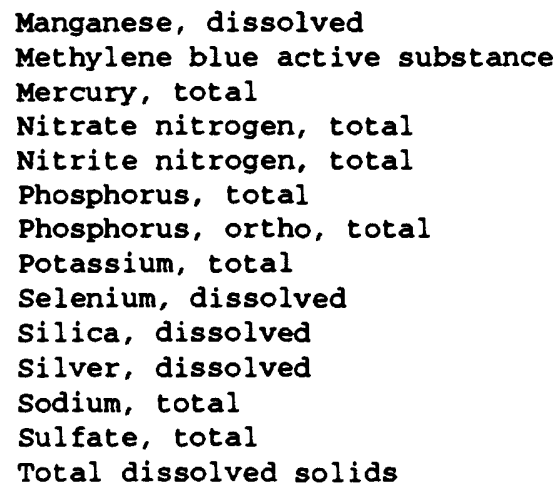

Volatile organic compounds

Analyzed by NWQL and NCDH

Benzene

Bromoform

Carbon tetrachloride

Chlorobenzene

Chloroform

Dichlorobromomethane

1,1-Dichloroethane

Ethylbenzene

Tetrachloroethylene PCE

Trichloroethylene TCE

Toluene

1,2-trans-Dichloroet hylene

1,1,1-Trichloroethane

1, 1,2-Trichloroethane

Trichlorofluoromethane ${ }^{b}$

Xylene
Analyzed by NWQL only

Chloroethane

2-Chloroethyl vinyl ether

Chloromethane

Dibromochloromethane

1,2-Dibromoet hy lene

1,2-Dichlorobenzene

1,3-Dichlorobenzene

1,4-Dichlorobenzene

Dichlorodifluoromethane

1,2-Dichloroethane

1,1-Dichloroethylene

1,2-Dichloropropane

cis-1, 3-Dichloropropene

trans-1,3-Dichloropropene

1,3-Dichloropropene

Methyl bromide

Methylene chloride

Styrene

$1,1,2,2$-Tet rachloroethane

Vinyl chloride

Pesticides

(Analysis done by NWQL unless otherwise noted)

Organochlorine Insecticides

Aldrin

Chlordane

DDD

$\mathrm{DDE}$

DDT

Dieldrin

Endosulfan

Endrin

Gross polychlorinated biphenyls ( $\mu \mathrm{g} / \mathrm{L}$ as PCB)

Gross polychlorinated napthalenes ( $\mu \mathrm{g} / \mathrm{L}$ as PCN)

Heptachlor

Heptachlor epoxide

Lindane

a Analyzed by NWQL only
Organochlorine Insecticides (cont'd)

Methoxychlor

Mirex Perthane

Toxaphene

Organophosphorus Insecticides

Diazinon

Ethion

Malathion

Methyl parathion

Methyl trithion

Parathion

Trithion 
Table 3.--Inorganic and organic chemical constituents for which water samples were analyzed (continued)

Pesticides (cont'd)

$\begin{array}{ll}\text { Triazine Herbicides } & \text { Chlorophenoxy-acid Herbicides } \\ \text { Alachlor } & 2,4-\mathrm{D} \\ \text { Ametryn } & 2,4-\mathrm{DP} \\ \text { Atrazine } & \text { Silvex } \\ \text { Cyanazine } & 2,4,5-\mathrm{T} \\ \text { Metolachlor } & \\ \text { Metribuzin } & \text { Carbamate Pesticides } \\ \text { Prometone } & \\ \text { Prometryn } & \text { Aldicarb } \\ \text { Propazine } & \text { Aldicarb Sulfoxide } \\ \text { Simazine } & \text { Aldicarb Sulfone } \\ \text { Simetryn } & \text { Carbofuran } \\ \text { Trifluralin } & 3 \text {-Hydroxycarbofuran } \\ & \text { Oxamyl } \\ & \text { Carbaryl } \\ & \text { Methomyl }\end{array}$

Semi-volatile compounds (methylene chloride extraction)

Base/Neutral-Extractable
Acenaphthene
Acenaphthylene
Anthracene
Benzo(a) anthracene
Benzo(b) fluoranthene
Benzo(k) fluoranthene
Benzo(g,h, i)perylene
Benzo(a)pyrene
4-Bromophenyl phenyl ether
n-Butyl benzyl phthalate
bis (2-Chlorethoxy methane)
bis(2-Chloroethyl) ether)
bis (2-Chloroisopropyl) ether
2-Chloronaphthalene
4-Chlorophenyl phenyl ether
Chrysene
Dibenzo(a,h) anthracene
1,2-Dichlorobenzene
1,3-Dichlorobenzene
1,4-Dichlorobenzene
Diethyl phthalate
Dimethyl phthalate
Di-n-butyl phthalate
2,4-Dinitrotoluene
2,6-Dinitrotoluene
Di-n-octylphthalate
bis (2-Ethylhexyl) phthalate
Fluoranthene

Base/Neutral Extractable (cont'd)

Fluorene

Hexachlorobenzene

Hexachlorobutadiene

Hexachlorocyclopentadiene

Hexachloroethane

Indeno $(1,2,3-c d)$ pyrene

Isophorone

Napht halene

Nitrobenzene

$N$-Nitrosodimethylamine

$N$ (B (B -Nitrosodi-n-propylamine

$N$ (B (B -Nitrosodiphenylamine

Phenanthrene

Pyrene

1,2,4-Trichlorobenzene

Acid Extractable

4-Chloro-3-methylphenol

2-Chlorophenol

2,4-Dichlorophenol

2,4-Dimethylphenol

2, 4-Dinitrophenol

2-Methyl-4,6-dinitrophenol

2-Nitrophenol

4-Nitrophenol

Pentachlorophenol

Phenol

C Analyzed by Suffolk County Department of Health Services laboratory. 
Table 4.--Major inorganic-ion concentrations and field constituent values in water samples from network wells

[mg/L, milligrams per liter; $\mu \mathrm{s} / \mathrm{cm}$, microsiemens per centimeter at 25 degrees Celsius; <, less than; --, no data]

\begin{tabular}{|c|c|c|c|c|c|c|c|c|c|c|}
\hline $\begin{array}{c}\text { Well } \\
\text { number }\end{array}$ & $\begin{array}{c}\text { Silica, } \\
\text { total } \\
\text { (mg/L } \\
\mathrm{SiO}_{2} \text { ) }\end{array}$ & $\begin{array}{c}\text { Calcium, } \\
\text { dis- } \\
\text { solved } \\
\text { (mg/L as } \\
\text { Ca) }\end{array}$ & $\begin{array}{l}\text { Magnes- } \\
\text { ium, } \\
\text { dis- } \\
\text { solved } \\
\text { (mg/L as } \\
\mathrm{Mg} \text { ) }\end{array}$ & $\begin{array}{c}\text { Sodium } \\
\text { dis- } \\
\text { solved } \\
\text { (mg/L as } \\
\mathrm{Na} \text { ) }\end{array}$ & $\begin{array}{l}\text { Potas- } \\
\text { sium, } \\
\text { dis- } \\
\text { solved } \\
\text { (mg/L as } \\
\text { K) }\end{array}$ & $\begin{array}{c}\text { Alka- } \\
\text { linity } \\
\text { (lab } \\
\mathrm{mg} / \mathrm{L} \text { as } \\
\mathrm{CaCO}_{3} \text { ) }\end{array}$ & $\begin{array}{c}\text { Sulfate } \\
\text { (mg/L as } \\
\left.\mathrm{SO}_{4}\right)\end{array}$ & $\begin{array}{l}\text { Chlo- } \\
\text { ride, } \\
\text { dis- } \\
\text { solved } \\
\text { (mg/L as } \\
\text { Cl) }\end{array}$ & $\begin{array}{l}\text { Fluo- } \\
\text { ride, } \\
\text { total } \\
\text { (mg/L } \\
\text { as F) }\end{array}$ & $\begin{array}{l}\text { Nitro- } \\
\text { gen, } \\
\text { nitrate } \\
\text { total } \\
\text { (mg/L as } \\
\text { N }\end{array}$ \\
\hline \multicolumn{11}{|c|}{ LONG-TERM SENERED SUBURBAN AREA } \\
\hline N 9057 & 10.7 & 21.9 & 3.5 & 11 & 3.6 & 8 & 35 & 32.4 & $<0.2$ & 8.70 \\
\hline N 9803 & 8.8 & 19.0 & 3.3 & 29 & 3.8 & 14 & 25 & 48.8 & $<0.2$ & 6.50 \\
\hline N 9914 & 7.6 & 28.2 & 6.4 & 24 & 2.4 & 34 & 47 & 39.2 & $<0.2$ & 5.20 \\
\hline N 9940 & 10.5 & 14.4 & 2.7 & 9.0 & 3.9 & 9 & 23 & 12.4 & $<0.2$ & 5.81 \\
\hline N 9941 & 9.1 & 18.5 & 5.7 & 22 & 5.0 & 7 & 31 & 31.6 & $<0.2$ & 11.0 \\
\hline N 9942 & 11.7 & 19.0 & 3.2 & 30 & 3.1 & 18 & 36 & 45.4 & $<0.2$ & 5.48 \\
\hline N 9943 & 10.2 & 27.6 & 8.8 & 83 & 3.8 & 28 & 44 & 143 & $<0.2$ & 4.41 \\
\hline N 9944 & 13.2 & 21.6 & 4.1 & 31 & 4.8 & 11 & 47 & 50.1 & $<0.2$ & 6.38 \\
\hline N 9945 & 8.7 & 18.1 & 3.7 & 17 & 1.9 & 17 & 38 & 30.9 & $<0.2$ & 4.42 \\
\hline N 9946 & 15.6 & 12.1 & 3.2 & 10 & 3.3 & 14 & 37 & 15.6 & $<0.2$ & 1.86 \\
\hline N 9947 & 22.0 & 21.2 & 12.3 & 11 & 2.1 & 40 & 43 & 27.0 & $<0.2$ & 4.93 \\
\hline N 9948 & 18.0 & 77.4 & 14.2 & 32 & 24.7 & 370 & $<5.0$ & 45.6 & 0.2 & $<0.01$ \\
\hline N 9949 & 10.3 & 35.0 & 6.7 & 16 & 0.8 & 64 & 45 & 24.6 & $<0.2$ & 3.85 \\
\hline N 9959 & 4.6 & 4.2 & 0.8 & 12 & 1.0 & 33 & 8.0 & 9.9 & $<0.2$ & $<0.01$ \\
\hline N 9962 & 6.2 & 28.9 & 3.2 & 11 & 2.9 & 50 & 29 & 16.2 & $<0.2$ & 4.69 \\
\hline N 9979 & 21.0 & 37.8 & 13.2 & 17 & 2.4 & 26 & 48 & 74.5 & $<0.2$ & 14.0 \\
\hline N 9982 & 20.1 & 25.7 & 7.2 & 17 & 1.7 & 18 & 43 & 34.5 & $<0.2$ & 5.05 \\
\hline N 9983 & 19.1 & 24.8 & 4.9 & 13 & 1.4 & 16 & 38 & 24.2 & $<0.2$ & 6.36 \\
\hline N 9984 & 13.5 & 22.8 & 2.6 & 21 & 2.5 & 12 & 27 & 33.4 & $<0.2$ & 6.45 \\
\hline N 10035 & 5.2 & 9.3 & 2.4 & 24 & 1.3 & 24 & 11 & 29.0 & $<0.2$ & 4.19 \\
\hline \multicolumn{11}{|c|}{ RECENTLY SEWERED SUBURBAN AREA } \\
\hline N 1197 & 12.6 & 21.9 & 3.2 & 23 & 5.6 & 11 & 33 & 36.2 & $<0.2$ & 10.0 \\
\hline N 8888 & 13.1 & 16.3 & 2.8 & 28 & 4.4 & 11 & 29 & 37.9 & $<0.2$ & 8.91 \\
\hline N 8984 & 4.0 & 8.6 & 2.3 & 12 & 1.4 & 21 & 16 & 22.7 & $<0.2$ & 2.71 \\
\hline N 9078 & 8.2 & 11.8 & 3.0 & 8.0 & 3.3 & 9 & 28 & 9.0 & $<0.2$ & 3.39 \\
\hline N 9079 & 5.1 & 28.7 & 4.7 & 56 & 3.9 & 59 & 26 & 114 & $<0.2$ & 2.27 \\
\hline N 9222 & 12.5 & 14.2 & 2.2 & 10 & 3.9 & 4 & 25 & 14.5 & $<0.2$ & 6.24 \\
\hline N 9354 & 15.6 & 19.6 & 3.3 & 28 & 4.8 & 15 & 36 & 29.2 & $<0.2$ & 9.82 \\
\hline N 9451 & 14.9 & 28.2 & 2.2 & 16 & 3.7 & 10 & 41 & 32.4 & $<0.2$ & 4.89 \\
\hline N 9917 & 6.0 & 24.8 & 3.3 & 29 & 2.1 & 42 & 22 & 64.7 & $<0.2$ & 0.16 \\
\hline N 9918 & 6.6 & 7.8 & 2.0 & 6.0 & 2.2 & 4 & $<5.0$ & 12.1 & $<0.2$ & 4.51 \\
\hline N 9919 & 12.9 & 19.9 & 4.1 & 31 & 5.3 & 6 & 26 & 50.9 & $<0.2$ & 14.0 \\
\hline N 9920 & 4.6 & 15.1 & 2.6 & 43 & 4.0 & 21 & 34 & 45.1 & $<0.2$ & 7.70 \\
\hline N 9924 & 9.2 & 20.2 & 2.3 & 47 & 4.3 & 23 & 27 & 69.8 & $<0.2$ & 5.25 \\
\hline N 9925 & 13.8 & 23.3 & 2.9 & 43 & 6.5 & 8 & 31 & 64.9 & $<0.2$ & 11.0 \\
\hline N 9926 & 4.2 & 6.3 & 2.3 & 11 & 1.6 & 7 & 7.0 & 26.6 & $<0.2$ & 1.50 \\
\hline N 9927 & 15.5 & 21.6 & 2.6 & 21 & 6.9 & 2 & 24 & 25.0 & $<0.2$ & 18.0 \\
\hline N 9928 & 15.9 & 17.3 & 3.1 & 23 & 8.2 & 3 & 24 & 24.5 & 0.5 & 20.0 \\
\hline N 9933 & 12.8 & 15.5 & 2.6 & 10 & 0.9 & 19 & 26 & 8.0 & $<0.2$ & 2.65 \\
\hline N 9938 & 8.6 & 13.1 & 7.3 & 36 & 1.9 & 8 & 26 & 70.8 & $<0.2$ & 3.96 \\
\hline N 9939 & 11.4 & 12.0 & 3.2 & 14 & 4.0 & 2 & 26 & 20.5 & $<0.2$ & 8.95 \\
\hline \multicolumn{11}{|c|}{ UNSEWERED SUBURBAN AREA } \\
\hline S 24771 & 10.2 & 8.6 & 5.1 & 20 & 2.2 & 34 & 13 & 18.5 & $<0.2$ & 6.46 \\
\hline S 29778 & 7.5 & 6.6 & 4.7 & 6.0 & 1.5 & 23 & 8.0 & 13.2 & $<0.2$ & 2.94 \\
\hline S 45207 & 12.5 & 14.1 & 3.7 & 14 & 3.2 & 14 & 19 & 12.6 & $<0.2$ & 7.63 \\
\hline S 45208 & 19.9 & 24.1 & 9.2 & 32 & 3.2 & 19 & 29 & 34.9 & $<0.2$ & 24.0 \\
\hline S 45210 & 18.0 & 23.5 & 10.1 & 9.0 & 1.5 & 31 & 37 & 10.2 & $<0.2$ & 12.0 \\
\hline
\end{tabular}


Table 4.--Major inorganic-ion concentrations and field constituent values in water samples from network wells (continued)

\begin{tabular}{|c|c|c|c|c|c|c|c|c|c|c|}
\hline $\begin{array}{c}\text { Well } \\
\text { number }\end{array}$ & $\begin{array}{c}\text { Silica, } \\
\text { total } \\
\text { (mg/L } \\
\mathrm{SiO}_{2} \text { ) }\end{array}$ & $\begin{array}{l}\text { Calcium, } \\
\text { dis- } \\
\text { solved } \\
\text { (mg/L as } \\
\text { Ca) }\end{array}$ & $\begin{array}{l}\text { Magnes- } \\
\text { ium, } \\
\text { dis- } \\
\text { solved } \\
\text { (mg/L as } \\
\mathrm{Mg} \text { ) }\end{array}$ & $\begin{array}{c}\text { Sodium } \\
\text { dis- } \\
\text { solved } \\
\text { (mg/L as } \\
\mathrm{Na} \text { ) }\end{array}$ & $\begin{array}{c}\text { Potas- } \\
\text { sium, } \\
\text { dis- } \\
\text { solved } \\
\text { (mg/L as } \\
\mathrm{K} \text { ) }\end{array}$ & $\begin{array}{c}\text { Alka- } \\
\text { linity } \\
\text { (lab } \\
\mathrm{mg} / \mathrm{L} \text { as } \\
\left.\mathrm{CaCO}_{3}\right)\end{array}$ & $\begin{array}{l}\text { Sulfate } \\
\left(\mathrm{mg}_{\mathrm{L}} \mathrm{L} \text { as }\right. \\
\left.\mathrm{SO}_{4}\right)\end{array}$ & $\begin{array}{l}\text { Chlo- } \\
\text { ride, } \\
\text { dis- } \\
\text { solved } \\
\text { (mg/L as } \\
\text { Cl) }\end{array}$ & $\begin{array}{l}\text { Fluo- } \\
\text { ride, } \\
\text { total } \\
\text { (mg/L } \\
\text { as F) } \\
\end{array}$ & $\begin{array}{c}\text { Nitro- } \\
\text { gen, } \\
\text { nitrate } \\
\text { total } \\
\text { (mg } / \mathrm{L} \text { as } \\
\mathrm{N} \\
\end{array}$ \\
\hline \multicolumn{11}{|c|}{ UNSEWERED SUBURBAN AREA (CONTINUED) } \\
\hline $\begin{array}{ll}S & 45594 \\
\text { S } & 46283 \\
\text { S } & 47220 \\
\text { S } & 48375 \\
\text { S } & 50513\end{array}$ & $\begin{array}{r}11.5 \\
8.1 \\
5.5 \\
6.9 \\
12.1\end{array}$ & $\begin{array}{r}8.1 \\
1.0 \\
<0.1 \\
6.5 \\
11.2\end{array}$ & $\begin{array}{l}3.0 \\
0.5 \\
0.8 \\
1.6 \\
4.5\end{array}$ & $\begin{array}{l}11 \\
3.0 \\
5.0 \\
70 \\
17\end{array}$ & $\begin{array}{l}1.9 \\
0.5 \\
0.4 \\
9.5 \\
3.5\end{array}$ & $\begin{array}{r}12 \\
7 \\
5 \\
39 \\
7\end{array}$ & $\begin{array}{l}14 \\
<5.0 \\
<5.0 \\
22 \\
27\end{array}$ & $\begin{array}{r}11.2 \\
6.3 \\
2.5 \\
62.1 \\
25.3\end{array}$ & $\begin{array}{l}<0.2 \\
<0.2 \\
<0.2 \\
<0.2 \\
<0.2\end{array}$ & $\begin{array}{c}4.31 \\
0.29 \\
0.85 \\
13.0 \\
8.32\end{array}$ \\
\hline $\begin{array}{ll}S & 64313 \\
S & 64314 \\
S & 64316 \\
S & 64318 \\
S & 64319\end{array}$ & $\begin{array}{r}2.4 \\
5.0 \\
6.6 \\
6.1 \\
10.8\end{array}$ & $\begin{array}{r}11.0 \\
22.1 \\
17.0 \\
2.2 \\
21.7\end{array}$ & $\begin{array}{l}1.0 \\
6.1 \\
5.8 \\
3.1 \\
5.5\end{array}$ & $\begin{array}{r}43 \\
154 \\
10 \\
16 \\
26\end{array}$ & $\begin{array}{l}1.8 \\
1.2 \\
2.8 \\
1.1 \\
5.0\end{array}$ & $\begin{array}{r}19 \\
54 \\
6 \\
8 \\
15\end{array}$ & $\begin{array}{l}<5.0 \\
16 \\
23 \\
<5.0 \\
21\end{array}$ & $\begin{array}{c}60.3 \\
217 \\
33.0 \\
25.4 \\
57.2\end{array}$ & $\begin{array}{l}<0.2 \\
<0.2 \\
<0.2 \\
<0.2 \\
<0.2\end{array}$ & $\begin{array}{l}0.24 \\
1.51 \\
7.75 \\
2.00 \\
6.79\end{array}$ \\
\hline $\begin{array}{ll}S & 65602 \\
S & 65607 \\
S & 68762 \\
S & 74286 \\
S & 75456\end{array}$ & $\begin{array}{r}17.3 \\
15.6 \\
12.0 \\
6.6 \\
10.1\end{array}$ & $\begin{array}{r}26.2 \\
16.0 \\
15.4 \\
1.1 \\
4.3\end{array}$ & $\begin{array}{l}5.1 \\
7.2 \\
3.5 \\
1.3 \\
2.8\end{array}$ & $\begin{array}{l}19 \\
23 \\
22 \\
3.0 \\
5.0\end{array}$ & $\begin{array}{l}5.7 \\
4.0 \\
1.9 \\
0.6 \\
0.8\end{array}$ & $\begin{array}{r}6 \\
7 \\
9 \\
6 \\
10\end{array}$ & $\begin{array}{r}32 \\
26 \\
20 \\
<5.0 \\
6.0\end{array}$ & $\begin{array}{r}26.2 \\
32.2 \\
22.7 \\
5.0 \\
11.8\end{array}$ & $\begin{array}{l}<0.2 \\
<0.2 \\
<0.2 \\
<0.2 \\
<0.2\end{array}$ & $\begin{array}{c}23.0 \\
16.0 \\
9.97 \\
1.08 \\
1.74\end{array}$ \\
\hline \multicolumn{11}{|c|}{ AGRICULTURAL AREA } \\
\hline $\begin{array}{ll}S & 51566 \\
S & 51567 \\
S & 51568 \\
S & 51571 \\
S & 51572\end{array}$ & $\begin{array}{r}10.5 \\
10.6 \\
8.9 \\
9.7 \\
12.8\end{array}$ & $\begin{array}{l}77.0 \\
76.0 \\
60.3 \\
25.3 \\
18.5\end{array}$ & $\begin{array}{r}12.6 \\
12.2 \\
9.2 \\
7.9 \\
4.1\end{array}$ & $\begin{array}{c}10 \\
9.0 \\
23 \\
11 \\
22\end{array}$ & $\begin{array}{l}4.4 \\
2.5 \\
5.2 \\
4.3 \\
6.4\end{array}$ & $\begin{array}{r}9 \\
11 \\
22 \\
9 \\
20\end{array}$ & $\begin{array}{c}140 \\
150 \\
79 \\
6.3 \\
31\end{array}$ & $\begin{array}{l}33.7 \\
27.2 \\
54.8 \\
28.4 \\
34.8\end{array}$ & $\begin{array}{l}<0.2 \\
<0.2 \\
<0.2 \\
<0.2 \\
<0.2\end{array}$ & $\begin{array}{c}18.0 \\
11.0 \\
17.0 \\
11.0 \\
9.91\end{array}$ \\
\hline $\begin{array}{ll}S & 51575 \\
S & 51576 \\
S & 51577 \\
S & 51578 \\
S & 51581\end{array}$ & $\begin{array}{r}9.2 \\
8.0 \\
10.4 \\
9.3 \\
8.8\end{array}$ & $\begin{array}{r}8.4 \\
17.8 \\
51.9 \\
11.5 \\
31.1\end{array}$ & $\begin{array}{r}1.6 \\
5.2 \\
10.1 \\
4.7 \\
7.9\end{array}$ & $\begin{array}{r}8.0 \\
6.0 \\
7.0 \\
<3.0 \\
8.0\end{array}$ & $\begin{array}{l}0.8 \\
4.3 \\
8.7 \\
1.8 \\
3.9\end{array}$ & $\begin{array}{r}32 \\
7 \\
7 \\
6 \\
8\end{array}$ & $\begin{array}{c}6.0 \\
45 \\
113 \\
37 \\
114\end{array}$ & $\begin{array}{r}8.4 \\
10.6 \\
22.2 \\
10.0 \\
20.3\end{array}$ & $\begin{array}{l}<0.2 \\
<0.2 \\
<0.2 \\
<0.2 \\
<0.2\end{array}$ & $\begin{array}{c}<0.01 \\
4.73 \\
8.91 \\
2.76 \\
3.51\end{array}$ \\
\hline $\begin{array}{ll}S & 51582 \\
S & 51587 \\
S & 51588 \\
S & 51589 \\
S & 52383\end{array}$ & $\begin{array}{r}10.5 \\
11.7 \\
8.7 \\
6.1 \\
4.1\end{array}$ & $\begin{array}{r}41.9 \\
33.1 \\
49.7 \\
7.0 \\
7.1\end{array}$ & $\begin{array}{r}7.7 \\
6.5 \\
10.1 \\
1.2 \\
1.4\end{array}$ & $\begin{array}{l}5.0 \\
14 \\
10 \\
21 \\
7.0\end{array}$ & $\begin{array}{r}3.8 \\
11.0 \\
4.5 \\
3.9 \\
4.5\end{array}$ & $\begin{array}{r}16 \\
20 \\
15 \\
8 \\
5\end{array}$ & $\begin{array}{r}80 \\
59 \\
97 \\
8.0 \\
<5.0\end{array}$ & $\begin{array}{l}20.1 \\
23.4 \\
24.1 \\
37.8 \\
23.4\end{array}$ & $\begin{array}{r}<0.2 \\
0.5 \\
<0.2 \\
0.3 \\
0.6\end{array}$ & $\begin{array}{c}8.31 \\
13.1 \\
11.0 \\
3.55 \\
4.96\end{array}$ \\
\hline \multicolumn{11}{|c|}{ UNDEVELOPED AREA } \\
\hline $\begin{array}{ll}\text { S } & 34742 \\
\text { S } & 46544 \\
\text { S } & 47755 \\
\text { S } & 48584 \\
\text { S } & 48946\end{array}$ & $\begin{array}{l}7.4 \\
9.7 \\
7.7 \\
7.1 \\
9.5\end{array}$ & $\begin{array}{r}6.0 \\
13.2 \\
3.1 \\
2.4 \\
16.9\end{array}$ & $\begin{array}{l}2.8 \\
5.7 \\
1.3 \\
1.0 \\
4.9\end{array}$ & $\begin{array}{r}3.0 \\
<3.0 \\
3.0 \\
<3.0 \\
9.0\end{array}$ & $\begin{array}{l}1.8 \\
0.7 \\
0.8 \\
0.6 \\
3.3\end{array}$ & $\begin{array}{r}9 \\
4 \\
5 \\
7 \\
21\end{array}$ & $\begin{array}{l}9.0 \\
31 \\
7.0 \\
<5.0 \\
22\end{array}$ & $\begin{array}{r}7.4 \\
7.4 \\
11.4 \\
4.7 \\
16.2\end{array}$ & $\begin{array}{l}<0.2 \\
<0.2 \\
<0.2 \\
<0.2 \\
<0.2\end{array}$ & $\begin{array}{r}1.08 \\
4.31 \\
<0.01 \\
<0.01 \\
6.50\end{array}$ \\
\hline $\begin{array}{ll}S & 54886 \\
S & 73807 \\
S & 73811 \\
S & 74293 \\
S & 74294\end{array}$ & $\begin{array}{r}4.7 \\
10.0 \\
8.9 \\
11.8 \\
5.4\end{array}$ & $\begin{array}{r}2.9 \\
18.3 \\
1.7 \\
6.0 \\
1.9\end{array}$ & $\begin{array}{l}0.4 \\
4.5 \\
0.9 \\
2.1 \\
0.3\end{array}$ & $\begin{array}{l}54 \\
5.0 \\
<3.0 \\
8.0 \\
33\end{array}$ & $\begin{array}{l}0.4 \\
2.7 \\
0.6 \\
0.9 \\
0.8\end{array}$ & $\begin{array}{r}5 \\
5 \\
8 \\
8 \\
15\end{array}$ & $\begin{array}{l}18 \\
8.0 \\
7.0 \\
12 \\
10\end{array}$ & $\begin{array}{r}74.0 \\
19.1 \\
4.2 \\
8.3 \\
44.7\end{array}$ & $\begin{array}{l}<0.2 \\
<0.2 \\
<0.2 \\
<0.2 \\
<0.2\end{array}$ & $\begin{array}{l}0.32 \\
0.02 \\
0.02 \\
3.64 \\
0.09\end{array}$ \\
\hline $\begin{array}{ll}S & 74295 \\
\text { S } & 74301 \\
\text { S } & 74307 \\
\text { S } & 86583 \\
\text { S } & 86584\end{array}$ & $\begin{array}{r}7.3 \\
9.9 \\
6.8 \\
9.3 \\
10.8\end{array}$ & $\begin{array}{r}1.4 \\
3.2 \\
4.2 \\
4.0 \\
14.0\end{array}$ & $\begin{array}{l}0.2 \\
0.8 \\
1.6 \\
4.4 \\
4.9\end{array}$ & $\begin{array}{r}8.0 \\
<3.0 \\
20 \\
5.0 \\
<3.0\end{array}$ & $\begin{array}{l}0.7 \\
0.6 \\
0.9 \\
0.9 \\
1.3\end{array}$ & $\begin{array}{l}7 \\
6 \\
4 \\
4 \\
4\end{array}$ & $\begin{array}{r}12 \\
6.0 \\
9.0 \\
<5.0 \\
18\end{array}$ & $\begin{array}{r}4.4 \\
3.6 \\
36.7 \\
11.7 \\
8.1\end{array}$ & $\begin{array}{l}<0.2 \\
<0.2 \\
<0.2 \\
<0.2 \\
<0.2\end{array}$ & $\begin{array}{c}<0.01 \\
<0.01 \\
0.24 \\
5.86 \\
7.70\end{array}$ \\
\hline
\end{tabular}


Table 4.--Major inorganic-ion concentrations and field constituent values in water samples from network wells (continued)

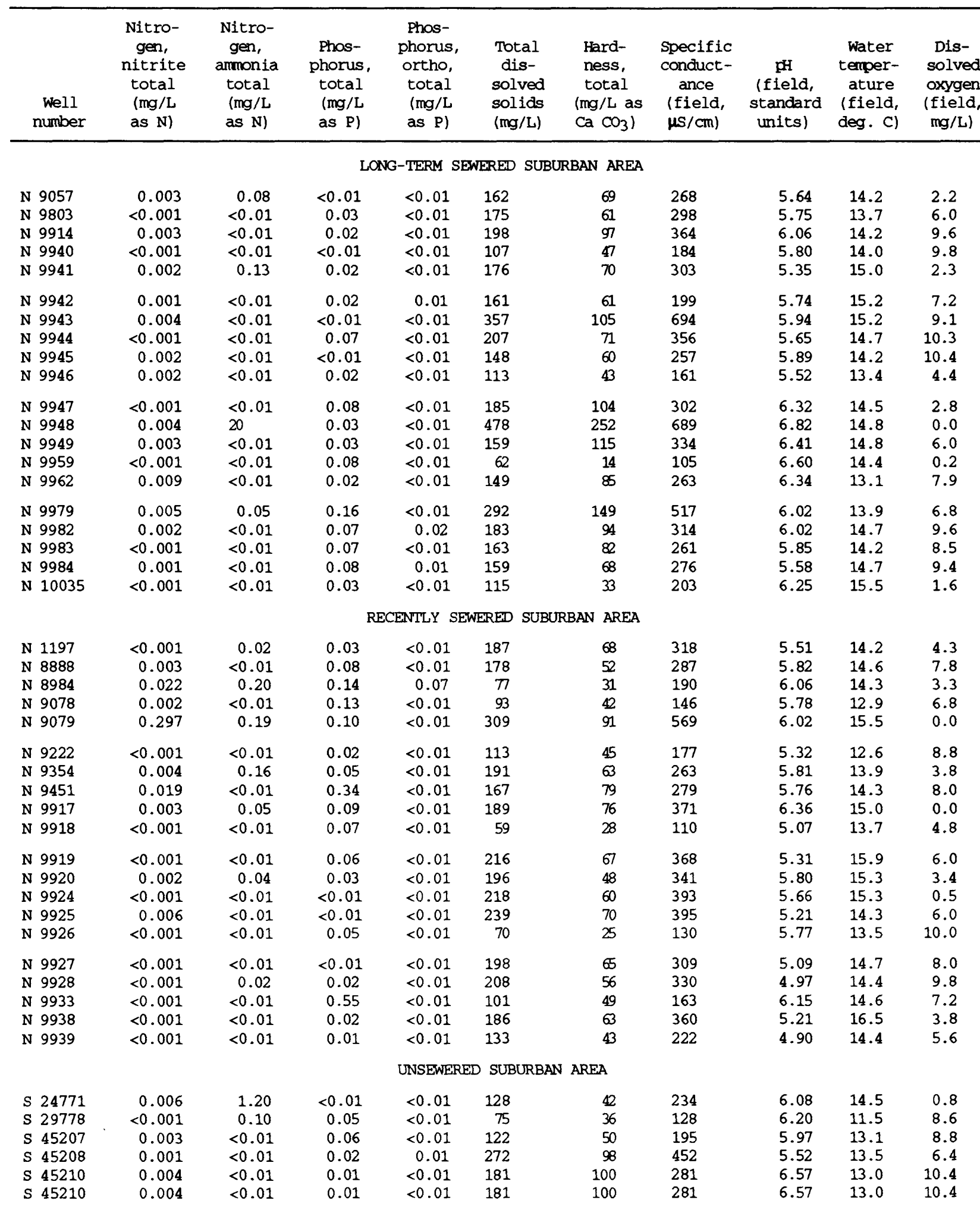


Table 4.--Major inorganic ion concentrations and field constituent values in water samples from network wells (continued).

\begin{tabular}{|c|c|c|c|c|c|c|c|c|c|c|}
\hline $\begin{array}{c}\text { Well } \\
\text { number }\end{array}$ & $\begin{array}{c}\text { Nitro- } \\
\text { gen, } \\
\text { nitrite } \\
\text { total } \\
\text { (mg/L } \\
\text { as } \mathrm{N} \text { ) }\end{array}$ & $\begin{array}{l}\text { Nitro- } \\
\text { gen, } \\
\text { ammonia } \\
\text { total } \\
\text { (mg/L } \\
\text { as N) }\end{array}$ & $\begin{array}{c}\text { Phos- } \\
\text { phorus, } \\
\text { total } \\
\text { (mg/L } \\
\text { as P) }\end{array}$ & $\begin{array}{c}\text { Phos- } \\
\text { phorus, } \\
\text { ortho, } \\
\text { total } \\
\text { (mg/L } \\
\text { as P) }\end{array}$ & $\begin{array}{l}\text { Total } \\
\text { dis- } \\
\text { solved } \\
\text { solids } \\
(\mathrm{mg} / \mathrm{L})\end{array}$ & $\begin{array}{l}\text { Hard- } \\
\text { ness, } \\
\text { total } \\
\text { (mg/L as } \\
\mathrm{Ca} \mathrm{CO}_{3} \text { ) }\end{array}$ & $\begin{array}{c}\text { Specific } \\
\text { conduct- } \\
\text { ance } \\
\text { (field, } \\
\mu \mathrm{s} / \mathrm{cm} \text { ) }\end{array}$ & $\begin{array}{c}\mathrm{pH} \\
\text { (field, } \\
\text { standard } \\
\text { units) }\end{array}$ & $\begin{array}{l}\text { Water } \\
\text { temper- } \\
\text { ature } \\
\text { (field, } \\
\text { deg. C) }\end{array}$ & $\begin{array}{c}\text { Dis- } \\
\text { solved } \\
\text { oxygen } \\
\text { (field } \\
\mathrm{mg} / \mathrm{L} \text { ) }\end{array}$ \\
\hline \multicolumn{11}{|c|}{ UNSEWERED SUBURBAN AREA (CONTINUED) } \\
\hline S 45594 & $<0.001$ & $<0.01$ & 0.02 & $<0.01$ & 87 & 33 & 128 & 5.41 & 12.6 & 8.7 \\
\hline S 46283 & $<0.001$ & 0.01 & 0.07 & $<0.01$ & 26 & 5 & 42 & 5.82 & 13.9 & 8.8 \\
\hline S 47220 & $<0.001$ & $<0.01$ & $<0.01$ & $<0.01$ & 21 & 4 & 32 & 6.07 & 10.8 & 10.2 \\
\hline S 48375 & 0.042 & 0.75 & 0.26 & 0.20 & 262 & 23 & 482 & 5.79 & 17.6 & 0.2 \\
\hline S 50513 & 0.003 & $<0.01$ & 0.03 & $<0.01$ & 142 & 46 & 230 & 5.57 & 12.9 & 8.6 \\
\hline S 64313 & 0.005 & 0.17 & 0.05 & 0.01 & 133 & 32 & 252 & 6.35 & 14.1 & 4.6 \\
\hline S 64314 & $<0.001$ & $<0.01$ & 0.02 & 0.02 & 461 & 80 & 886 & 5.67 & 13.5 & 6.0 \\
\hline S 64316 & 0.003 & $<0.01$ & 0.08 & $<0.01$ & 136 & 66 & 248 & 5.43 & 12.6 & 9.1 \\
\hline S 64318 & $<0.001$ & $<0.01$ & $<0.01$ & $<0.01$ & 68 & 18 & 127 & 5.70 & 12.4 & 10.6 \\
\hline S 64319 & $<0.001$ & $<0.01$ & 0.03 & $<0.01$ & 186 & 77 & 330 & 5.64 & 12.2 & 7.1 \\
\hline S 65602 & 0.002 & $<0.01$ & 0.20 & $<0.01$ & 238 & 86 & 380 & 5.31 & 13.9 & 7.4 \\
\hline S 65607 & 0.002 & $<0.01$ & 0.04 & $<0.01$ & 200 & 70 & 323 & 5.35 & 12.2 & 7.4 \\
\hline S 68762 & 0.002 & $<0.01$ & 0.10 & 0.05 & 147 & 53 & 228 & 5.46 & 13.8 & 6.8 \\
\hline S 74286 & $<0.001$ & $<0.01$ & 0.07 & $<0.01$ & 26 & 8 & 52 & 5.90 & 13.9 & 10.6 \\
\hline S 75456 & $<0.001$ & $<0.01$ & 0.07 & $<0.01$ & 55 & 22 & 82 & 5.90 & 10.9 & 11.0 \\
\hline \multicolumn{11}{|c|}{ AGRICULTURAL AREA } \\
\hline S 51566 & 0.002 & $<0.01$ & $<0.01$ & $<0.01$ & 373 & 244 & 544 & 5.85 & 12.1 & 9.4 \\
\hline S 51567 & 0.003 & $<0.01$ & $<0.01$ & $<0.01$ & 342 & 240 & 521 & 5.81 & 11.9 & 10.5 \\
\hline S 51568 & 0.059 & 0.25 & 0.08 & $<0.01$ & 330 & 188 & 512 & 6.30 & 12.3 & 8.9 \\
\hline S 51571 & $<0.001$ & 0.03 & $<0.01$ & $<0.01$ & 205 & 96 & 382 & 5.85 & 12.2 & 10.2 \\
\hline S 51572 & 0.032 & 0.74 & 0.32 & $<0.01$ & 193 & 63 & 309 & 5.74 & 12.2 & 0.0 \\
\hline S 51575 & $<0.001$ & 0.28 & 0.10 & $<0.01$ & 67 & 28 & 102 & 6.58 & 13.5 & 0.5 \\
\hline S 51576 & $<0.001$ & $<0.01$ & 0.08 & $<0.01$ & 122 & 66 & 191 & 5.55 & 11.9 & 10.0 \\
\hline S 51577 & 0.001 & $<0.01$ & 0.01 & $<0.01$ & 267 & 171 & 421 & 5.45 & 12.0 & 10.1 \\
\hline S 51578 & 0.004 & $<0.01$ & 0.07 & $<0.01$ & 91 & 48 & 156 & 6.11 & 11.4 & 10.4 \\
\hline S 51581 & $<0.001$ & $<0.01$ & $<0.01$ & $<0.01$ & 216 & 110 & 343 & 5.98 & 12.9 & 10.0 \\
\hline S 51582 & 0.004 & $<0.01$ & 0.25 & $<0.01$ & 216 & 136 & 356 & 6.12 & 12.1 & 10.4 \\
\hline S 51587 & 0.024 & 0.03 & 0.07 & $<0.01$ & 229 & 109 & 358 & 5.90 & 12.5 & 9.0 \\
\hline S 51588 & 0.020 & 0.38 & 0.17 & 0.03 & 265 & 166 & 372 & 6.10 & 12.3 & 6.6 \\
\hline S 51589 & 0.004 & $<0.01$ & - & - & 108 & 22 & 187 & 5.12 & 11.4 & 2.6 \\
\hline S 52383 & 0.006 & 0.07 & 0.05 & 0.01 & 73 & 23 & 151 & 5.23 & 11.9 & 8.0 \\
\hline \multicolumn{11}{|c|}{ UNDEVELOPED AREA } \\
\hline S 34742 & $<0.001$ & $<0.01$ & 0.01 & $<0.01$ & 48 & 27 & 80 & 5.83 & 10.8 & 10.1 \\
\hline S 46544 & $<0.001$ & $<0.01$ & $<0.01$ & $<0.01$ & 89 & 56 & 156 & 6.40 & 11.8 & 10.8 \\
\hline S 47755 & $<0.001$ & $<0.01$ & 0.11 & 0.05 & 38 & 13 & 71 & 6.67 & 12.5 & 7.9 \\
\hline S 48584 & 0.002 & $<0.01$ & $<0.01$ & $<0.01$ & 20 & 10 & 45 & 6.58 & 11.2 & 10.6 \\
\hline S 48946 & 0.032 & 0.27 & 0.09 & 0.03 & 129 & 62 & 225 & 5.95 & 13.1 & 3.2 \\
\hline S 54886 & $<0.001$ & $<0.01$ & $<0.01$ & $<0.01$ & 159 & 9 & 321 & 5.66 & 12.7 & 11.2 \\
\hline S 73807 & $<0.001$ & $<0.01$ & 0.02 & $<0.01$ & 71 & 64 & 101 & 5.74 & 11.7 & 11.1 \\
\hline S 73811 & $<0.001$ & $<0.01$ & 0.07 & $<0.01$ & 28 & 8 & 47 & 6.35 & 10.4 & 11.4 \\
\hline S 74293 & 0.001 & $<0.01$ & 0.09 & 0.02 & 70 & 24 & 106 & 5.74 & 12.2 & 10.5 \\
\hline S 74294 & 0.002 & $<0.01$ & $<0.01$ & $<0.01$ & 105 & 6 & 194 & 5.65 & 12.5 & 1.0 \\
\hline S 74295 & $<0.001$ & $<0.01$ & $<0.01$ & $<0.01$ & 38 & 4 & 67 & 6.04 & 11.6 & 11.8 \\
\hline S 74301 & 0.001 & $<0.01$ & 0.04 & $<0.01$ & 28 & 11 & 46 & 6.11 & 10.7 & 11.4 \\
\hline S 74307 & $<0.001$ & $<0.01$ & $<0.01$ & $<0.01$ & 82 & 17 & 161 & 5.89 & 11.8 & 11.2 \\
\hline S 86583 & $<0.001$ & $<0.01$ & 0.25 & $<0.01$ & 64 & 28 & 114 & 5.89 & 11.4 & 10.5 \\
\hline S 86584 & $<0.001$ & $<0.01$ & 0.03 & $<0.01$ & 94 & 55 & 148 & 6.26 & 11.0 & 11.4 \\
\hline
\end{tabular}


Table 5.--Inorganic trace-element concentrations in water samples from network wells

[mg/L, milligrams per liter; ug/L, micrograms per liter;

$$
<\text {, less than; -., no data] }
$$

\begin{tabular}{|c|c|c|c|c|c|c|c|c|c|}
\hline $\begin{array}{c}\text { well } \\
\text { number }\end{array}$ & $\begin{array}{c}\text { Iron, } \\
\text { dis- } \\
\text { solved } \\
\text { (ug/L as } \\
\mathrm{Fe} \text { ) }\end{array}$ & $\begin{array}{c}\text { Manga- } \\
\text { nese, } \\
\text { dis- } \\
\text { solved } \\
\text { (ug/L as } \\
\text { Mn) }\end{array}$ & $\begin{array}{l}\text { Barium, } \\
\text { dis- } \\
\text { solved } \\
\text { (ug/L as } \\
\mathrm{Ba} \text { ) }\end{array}$ & $\begin{array}{c}\text { Boron, } \\
\text { dis- } \\
\text { solved } \\
\text { (ug/L as } \\
\text { B) } \\
\end{array}$ & $\begin{array}{c}\text { Cadmium, } \\
\text { dis- } \\
\text { sovled } \\
\text { (ug/L } \\
\text { as Cd) } \\
\end{array}$ & $\begin{array}{c}\text { Chromium, } \\
\text { dissolved } \\
\text { (ug/L } \\
\text { as } \mathrm{Cr} \text { ) }\end{array}$ & $\begin{array}{l}\text { Copper, } \\
\text { dis- } \\
\text { solved } \\
\text { (ug/L as } \\
\text { Cu) }\end{array}$ & $\begin{array}{c}\text { Lead } \\
\text { dis- } \\
\text { solved } \\
\text { (ug/L as } \\
\text { Pb) }\end{array}$ & $\begin{array}{r}\text { Methyler } \\
\text { blue act } \\
\text { substanc } \\
(\mathrm{mg} / \mathrm{L}) \\
\end{array}$ \\
\hline \multicolumn{10}{|c|}{ LONG-TERM SEWERED SUBURBAN AREA } \\
\hline $\begin{array}{l}\text { N } 9057 \\
\text { N } 9803 \\
\text { N } 9914 \\
\text { N } 9940 \\
\text { N } 9941\end{array}$ & $\begin{array}{l}<50 \\
<50 \\
<50 \\
<50 \\
<50\end{array}$ & $\begin{array}{l}180 \\
<50 \\
<50 \\
<50 \\
190\end{array}$ & $\begin{array}{l}<200 \\
<200 \\
<200 \\
<200 \\
<200\end{array}$ & $\begin{array}{r}110 \\
50 \\
40 \\
20 \\
130\end{array}$ & $\begin{array}{l}<1 \\
<1 \\
<1 \\
<1 \\
<1\end{array}$ & $\begin{array}{l}<10 \\
<10 \\
<10 \\
<10 \\
<10\end{array}$ & $\begin{array}{l}<50 \\
<50 \\
<50 \\
<50 \\
<50\end{array}$ & $\begin{array}{l}<10 \\
<10 \\
<10 \\
<10 \\
<10\end{array}$ & $\begin{array}{l}<0.02 \\
<0.02 \\
<0.02 \\
<0.02 \\
<0.02\end{array}$ \\
\hline $\begin{array}{l}\text { N } 9942 \\
\text { N } 9943 \\
\text { N } 9944 \\
\text { N } 9945 \\
\text { N } 9946\end{array}$ & $\begin{array}{l}<50 \\
<50 \\
<50 \\
<50 \\
<50\end{array}$ & $\begin{array}{l}<50 \\
<50 \\
<50 \\
<50 \\
<50\end{array}$ & $\begin{array}{l}<200 \\
<200 \\
<200 \\
<200 \\
<200\end{array}$ & $\begin{array}{l}60 \\
60 \\
60 \\
50 \\
20\end{array}$ & $\begin{array}{l}<1 \\
<1 \\
<1 \\
<1 \\
<1\end{array}$ & $\begin{array}{l}<10 \\
<10 \\
<10 \\
<10 \\
<10\end{array}$ & $\begin{array}{l}<50 \\
<50 \\
<50 \\
<50 \\
<50\end{array}$ & $\begin{array}{l}<10 \\
<10 \\
<10 \\
<10 \\
<10\end{array}$ & $\begin{array}{l}<0.02 \\
<0.02 \\
<0.02 \\
<0.02 \\
<0.02\end{array}$ \\
\hline $\begin{array}{l}\text { N } 9947 \\
\text { N } 9948 \\
\text { N } 9949 \\
\text { N } 9959 \\
\text { N } 9962\end{array}$ & $\begin{array}{r}390 \\
14,800 \\
<50 \\
1,580 \\
530\end{array}$ & $\begin{array}{r}<50 \\
2,750 \\
<50 \\
70 \\
<50\end{array}$ & $\begin{array}{l}<200 \\
<200 \\
<200 \\
<200 \\
<200\end{array}$ & $\begin{array}{r}60 \\
340 \\
150 \\
40 \\
50\end{array}$ & $\begin{array}{l}<1 \\
<1 \\
<1 \\
<1 \\
<1\end{array}$ & $\begin{array}{l}<10 \\
<10 \\
<10 \\
<10 \\
<10\end{array}$ & $\begin{array}{l}<50 \\
<50 \\
<50 \\
<50 \\
<50\end{array}$ & $\begin{array}{l}<10 \\
<10 \\
<10 \\
<10 \\
<10\end{array}$ & $\begin{array}{l}<0.02 \\
<0.02 \\
<0.02 \\
<0.02 \\
<0.02\end{array}$ \\
\hline $\begin{array}{l}\text { N } 9979 \\
\text { N } 9982 \\
\text { N } 9983 \\
\text { N } 9984 \\
\text { N } 10035\end{array}$ & $\begin{array}{r}190 \\
50 \\
<50 \\
<50 \\
<50\end{array}$ & $\begin{array}{l}<50 \\
<50 \\
<50 \\
<50 \\
<50\end{array}$ & $\begin{array}{r}<200 \\
400 \\
<200 \\
<200 \\
<200\end{array}$ & $\begin{array}{l}50 \\
70 \\
80 \\
60 \\
50\end{array}$ & $\begin{array}{l}<1 \\
<1 \\
<1 \\
<1 \\
<1\end{array}$ & $\begin{array}{l}<10 \\
<10 \\
<10 \\
<10 \\
<10\end{array}$ & $\begin{array}{l}<50 \\
<50 \\
<50 \\
<50 \\
<50\end{array}$ & $\begin{array}{l}<10 \\
<10 \\
<10 \\
<10 \\
<10\end{array}$ & $\begin{array}{l}<0.02 \\
<0.02 \\
<0.02 \\
<0.02 \\
<0.02\end{array}$ \\
\hline \multicolumn{10}{|c|}{ RECENTLY SEWERED SUBURBAN AREA } \\
\hline $\begin{array}{ll}N & 1197 \\
N & 8888 \\
N & 8984 \\
N & 9078 \\
N & 9079\end{array}$ & $\begin{array}{r}150 \\
230 \\
120 \\
150 \\
5,550\end{array}$ & $\begin{array}{r}160 \\
120 \\
<50 \\
<50 \\
19,000\end{array}$ & $\begin{array}{l}<200 \\
<200 \\
<200 \\
<200 \\
<200\end{array}$ & $\begin{array}{r}170 \\
130 \\
60 \\
30 \\
90\end{array}$ & $\begin{array}{l}<1 \\
<1 \\
<1 \\
<1 \\
<1\end{array}$ & $\begin{array}{r}<10 \\
<10 \\
<10 \\
40 \\
<10\end{array}$ & $\begin{array}{r}<50 \\
60 \\
<50 \\
<50 \\
<50\end{array}$ & $\begin{array}{r}<10 \\
<10 \\
<10 \\
60 \\
<10\end{array}$ & $\begin{array}{r}<0.02 \\
<0.02 \\
0.13 \\
<0.02 \\
<0.02\end{array}$ \\
\hline $\begin{array}{l}\text { N } 9222 \\
\text { N } 9354 \\
\text { N } 9451 \\
\text { N } 9917 \\
\text { N } 9918\end{array}$ & $\begin{array}{r}<50 \\
910 \\
<50 \\
7,400 \\
<50\end{array}$ & $\begin{array}{r}180 \\
900 \\
300 \\
3,500 \\
<50\end{array}$ & $\begin{array}{l}<200 \\
<200 \\
<200 \\
<200 \\
<200\end{array}$ & $\begin{array}{r}70 \\
230 \\
80 \\
110 \\
20\end{array}$ & $\begin{array}{l}<1 \\
<1 \\
<1 \\
<1 \\
<1\end{array}$ & $\begin{array}{l}<10 \\
<10 \\
<10 \\
<10 \\
<10\end{array}$ & $\begin{array}{l}<50 \\
<50 \\
<50 \\
<50 \\
<50\end{array}$ & $\begin{array}{l}<10 \\
<10 \\
<10 \\
<10 \\
<10\end{array}$ & $\begin{array}{l}<0.02 \\
<0.02 \\
<0.02 \\
<0.02 \\
<0.02\end{array}$ \\
\hline $\begin{array}{l}\text { N } 9919 \\
\text { N } 9920 \\
\text { N } 9924 \\
\text { N } 9925 \\
\text { N } 9926\end{array}$ & $\begin{array}{r}190 \\
850 \\
<50 \\
<50 \\
60\end{array}$ & $\begin{array}{l}240 \\
200 \\
810 \\
480 \\
<50\end{array}$ & $\begin{array}{l}<200 \\
<200 \\
<200 \\
<200 \\
<200\end{array}$ & $\begin{array}{r}110 \\
60 \\
80 \\
100 \\
20\end{array}$ & $\begin{array}{l}<1 \\
<1 \\
<1 \\
<1 \\
<1\end{array}$ & $\begin{array}{l}<10 \\
<10 \\
<10 \\
<10 \\
<10\end{array}$ & $\begin{array}{l}<50 \\
<50 \\
<50 \\
<50 \\
<50\end{array}$ & $\begin{array}{l}<10 \\
<10 \\
<10 \\
<10 \\
<10\end{array}$ & $\begin{array}{l}<0.02 \\
<0.02 \\
<0.02 \\
<0.02 \\
<0.02\end{array}$ \\
\hline $\begin{array}{l}\text { N } 9927 \\
\text { N } 9928 \\
\text { N } 9933 \\
\text { N } 9938 \\
\text { N } 9939\end{array}$ & $\begin{array}{l}<50 \\
<50 \\
<50 \\
<50 \\
<50\end{array}$ & $\begin{array}{r}660 \\
1.250 \\
<50 \\
110 \\
950\end{array}$ & $\begin{array}{l}<200 \\
<200 \\
<200 \\
<200 \\
<200\end{array}$ & $\begin{array}{r}80 \\
70 \\
360 \\
<10\end{array}$ & $\begin{array}{l}<1 \\
<1 \\
<1 \\
<1 \\
<1\end{array}$ & $\begin{array}{l}<10 \\
<10 \\
<10 \\
<10 \\
<10\end{array}$ & $\begin{array}{r}<50 \\
<50 \\
60 \\
<50 \\
<50\end{array}$ & $\begin{array}{l}<10 \\
<10 \\
<10 \\
<10 \\
<10\end{array}$ & $\begin{array}{l}<0.02 \\
<0.02 \\
<0.02 \\
<0.02 \\
<0.02\end{array}$ \\
\hline
\end{tabular}


Table 5.--Inorganic trace-element concentrations in water samples from network wells (continued)

\begin{tabular}{|c|c|c|c|c|c|c|c|c|c|}
\hline $\begin{array}{c}\text { Well } \\
\text { number }\end{array}$ & $\begin{array}{c}\text { Iron, } \\
\text { dis- } \\
\text { solved } \\
\text { (ug/L as } \\
\text { Fe) } \\
\end{array}$ & $\begin{array}{c}\text { Manga- } \\
\text { nese, } \\
\text { dis- } \\
\text { solved } \\
\text { (ug/L as } \\
\text { Mn) }\end{array}$ & $\begin{array}{l}\text { Barium, } \\
\text { dis- } \\
\text { solved } \\
\text { (ug/L as } \\
\mathrm{Ba})\end{array}$ & $\begin{array}{c}\text { Boron, } \\
\text { dis- } \\
\text { solved } \\
\text { (ug/L as } \\
\text { B) }\end{array}$ & $\begin{array}{l}\text { Cadmium, } \\
\text { dis- } \\
\text { sovled } \\
\text { (ug/L } \\
\text { as Cd) }\end{array}$ & $\begin{array}{l}\text { Chromium, } \\
\text { dis- } \\
\text { solved } \\
\text { (ug/L } \\
\text { as Cr) }\end{array}$ & $\begin{array}{l}\text { Copper, } \\
\text { dis- } \\
\text { solved } \\
\text { (ug/L as } \\
\text { Cu) }\end{array}$ & $\begin{array}{l}\text { Lead } \\
\text { dis- } \\
\text { solved } \\
\text { (ug/L as } \\
\mathrm{Pb} \text { ) }\end{array}$ & $\begin{array}{c}\text { Methylene } \\
\text { blue active } \\
\text { substances } \\
(\mathrm{mg} / \mathrm{L})\end{array}$ \\
\hline \multicolumn{10}{|c|}{ UNSEWERED SUBURBAN AREA } \\
\hline S 24771 & $<50$ & $<50$ & $<200$ & 40 & $<1$ & $<10$ & $<50$ & $<10$ & $<0.02$ \\
\hline S 29778 & 60 & $<50$ & $<200$ & 20 & 1 & $<10$ & $<50$ & $<10$ & $<0.02$ \\
\hline S 45207 & 110 & $<50$ & $<200$ & 40 & $<1$ & $<10$ & $<50$ & $<10$ & $<0.02$ \\
\hline S 45208 & 2,000 & 210 & $<200$ & 150 & $<1$ & $<10$ & $<50$ & $<10$ & $<0.02$ \\
\hline S 45210 & $<50$ & $<50$ & $<200$ & 20 & $<1$ & $<10$ & $<50$ & $<10$ & $<0.02$ \\
\hline S 45594 & 110 & $<50$ & $<200$ & 20 & $<1$ & $<10$ & $<50$ & $<10$ & $<0.02$ \\
\hline S 46283 & 370 & 70 & $<200$ & 10 & $<1$ & $<10$ & $<50$ & $<10$ & $<0.02$ \\
\hline S 47220 & 110 & 90 & $<200$ & $<10$ & $<1$ & $<10$ & $<50$ & $<10$ & $<0.02$ \\
\hline S 48375 & 150 & 700 & $<200$ & 350 & $<1$ & $<10$ & $<50$ & $<10$ & 0.02 \\
\hline S 50513 & $<50$ & $<50$ & $<200$ & 70 & $<1$ & $<10$ & $<50$ & $<10$ & $<0.02$ \\
\hline S 64313 & $<50$ & 1,090 & $<200$ & $<10$ & $<1$ & $<10$ & $<50$ & $<10$ & $<0.02$ \\
\hline S 64314 & $<50$ & $<50$ & $<200$ & 30 & $<1$ & $<10$ & $<50$ & $<10$ & $<0.02$ \\
\hline S 64316 & $<50$ & 60 & $<200$ & 20 & $<1$ & $<10$ & $<50$ & $<10$ & $<0.02$ \\
\hline S 64318 & $<50$ & $<50$ & $<200$ & $<10$ & $<1$ & $<10$ & $<50$ & $<10$ & $<0.02$ \\
\hline S 64319 & $<50$ & $<50$ & $<200$ & 20 & $<1$ & $<10$ & $<50$ & $<10$ & $<0.02$ \\
\hline S 65602 & $<50$ & 900 & $<200$ & 80 & 3 & $<10$ & $<50$ & $<10$ & $<0.02$ \\
\hline S 65607 & $<50$ & 330 & 300 & 70 & $<1$ & $<10$ & $<50$ & $<10$ & $<0.02$ \\
\hline S 68762 & $<50$ & $<50$ & $<200$ & 60 & $<1$ & $<10$ & $<50$ & $<10$ & $<0.02$ \\
\hline S 74286 & $<50$ & $<50$ & $<200$ & 10 & $<1$ & $<10$ & $<50$ & $<10$ & $<0.02$ \\
\hline S 75456 & $<50$ & $<50$ & $<200$ & $<10$ & $<1$ & $<10$ & $<50$ & 10 & $<0.02$ \\
\hline \multicolumn{10}{|c|}{ AGRICULTURAL AREA } \\
\hline S 51566 & 70 & $<50$ & $<200$ & 90 & 2 & $<10$ & $<50$ & $<10$ & $<0.02$ \\
\hline S 51567 & 90 & $<50$ & $<200$ & 140 & $<1$ & $<10$ & $<50$ & $<10$ & $<0.02$ \\
\hline S 51568 & 380 & 90 & $<200$ & 100 & $<1$ & $<10$ & $<50$ & $<10$ & $<0.02$ \\
\hline S 51571 & 1,850 & 70 & $<200$ & 20 & $<1$ & $<10$ & $<50$ & $<10$ & $<0.02$ \\
\hline S 51572 & 4,300 & 1,500 & $<200$ & 50 & $<1$ & $<10$ & $<50$ & $<10$ & $<0.02$ \\
\hline S 51575 & 4,900 & 70 & $<200$ & 50 & $<1$ & $<10$ & $<50$ & $<10$ & $<0.02$ \\
\hline S 51576 & 90 & 90 & $<200$ & 320 & $<1$ & $<10$ & $<50$ & 20 & $<0.02$ \\
\hline S 51577 & $<50$ & 270 & $<200$ & 90 & $<1$ & $<10$ & $<50$ & $<10$ & $<0.02$ \\
\hline S 51578 & 820 & 50 & $<200$ & 30 & $<1$ & $<10$ & $<50$ & $<10$ & $<0.02$ \\
\hline S 51581 & 1,120 & 60 & $<200$ & 80 & $<1$ & $<10$ & $<50$ & $<10$ & $<0.02$ \\
\hline S 51582 & $<50$ & $<50$ & $<200$ & 80 & $<1$ & $<10$ & $<50$ & $<10$ & $<0.02$ \\
\hline S 51587 & 200 & 310 & 200 & 60 & 2 & $<10$ & $<50$ & $<10$ & $<0.02$ \\
\hline S 51588 & 2,750 & 170 & $<200$ & 260 & $<1$ & $<10$ & $<50$ & 10 & $<0.02$ \\
\hline S 51589 & 1,190 & 130 & $<200$ & 60 & 2 & $<10$ & $<50$ & $<10$ & $<0.02$ \\
\hline S 52383 & 200 & 120 & $<200$ & 50 & $<1$ & $<10$ & $<50$ & $<10$ & $<0.02$ \\
\hline
\end{tabular}


Table 5.--Inorganic trace-element concentrations in water samples from network wells (continued)

\begin{tabular}{|c|c|c|c|c|c|c|c|c|c|}
\hline $\begin{array}{c}\text { Well } \\
\text { number }\end{array}$ & $\begin{array}{c}\text { Iron, } \\
\text { dis- } \\
\text { solved } \\
\text { (ug/L as } \\
\text { Fe) }\end{array}$ & $\begin{array}{l}\text { Manga- } \\
\text { nese, } \\
\text { dis- } \\
\text { solved } \\
\text { (ug/L as } \\
\text { Mn) }\end{array}$ & $\begin{array}{l}\text { Barium, } \\
\text { dis- } \\
\text { solved } \\
\text { (ug/L as } \\
\text { Ba) }\end{array}$ & $\begin{array}{c}\text { Boron, } \\
\text { dis- } \\
\text { solved } \\
\text { (ug/L as } \\
\text { B) }\end{array}$ & $\begin{array}{c}\text { Cadmium, } \\
\text { dis- } \\
\text { sovled } \\
\text { (ug/L } \\
\text { as Cd) }\end{array}$ & $\begin{array}{c}\text { Chromium, } \\
\text { dissolved } \\
\text { (ug/L } \\
\text { as Cr) }\end{array}$ & $\begin{array}{l}\text { Copper, } \\
\text { dis- } \\
\text { solved } \\
\text { (ug/L as } \\
\text { Cu) }\end{array}$ & $\begin{array}{c}\text { Lead } \\
\text { dis- } \\
\text { solved } \\
\text { (ug/L as } \\
\mathrm{Pb} \text { ) }\end{array}$ & $\begin{array}{c}\text { Methylene } \\
\text { blue active } \\
\text { substances } \\
\text { (mg/L) }\end{array}$ \\
\hline \multicolumn{10}{|c|}{ UNDEVELOPED AREA } \\
\hline $\begin{array}{ll}\text { S } & 34742 \\
\text { S } & 46544 \\
\text { S } & 47755 \\
\text { S } & 48584 \\
\text { S } & 48946\end{array}$ & $\begin{array}{r}<50 \\
<50 \\
70 \\
<50 \\
4,800\end{array}$ & $\begin{array}{l}<50 \\
<50 \\
<50 \\
<50 \\
<50\end{array}$ & $\begin{array}{l}<200 \\
<200 \\
<200 \\
<200 \\
<200\end{array}$ & $\begin{array}{l}10 \\
20 \\
10 \\
10 \\
30\end{array}$ & $\begin{array}{l}<1 \\
<1 \\
4 \\
4 \\
<1\end{array}$ & $\begin{array}{l}<10 \\
<10 \\
<10 \\
<10 \\
<10\end{array}$ & $\begin{array}{l}<50 \\
<50 \\
<50 \\
<50 \\
<50\end{array}$ & $\begin{array}{l}<10 \\
<10 \\
<10 \\
<10 \\
<10\end{array}$ & $\begin{array}{l}<0.02 \\
<0.02 \\
<0.02 \\
<0.02 \\
<0.02\end{array}$ \\
\hline $\begin{array}{ll}\text { S } & 54886 \\
\text { S } & 73807 \\
\text { S } & 73811 \\
\text { S } & 74293 \\
\text { S } & 74294\end{array}$ & $\begin{array}{l}<50 \\
<50 \\
<50 \\
<50 \\
<50\end{array}$ & $\begin{array}{l}<50 \\
<50 \\
<50 \\
<50 \\
<50\end{array}$ & $\begin{array}{l}<200 \\
<200 \\
<200 \\
<200 \\
<200\end{array}$ & $\begin{array}{r}10 \\
10 \\
<10 \\
40 \\
<10\end{array}$ & $\begin{array}{l}<1 \\
<1 \\
<1 \\
4 \\
<1\end{array}$ & $\begin{array}{l}<10 \\
<10 \\
<10 \\
<10 \\
<10\end{array}$ & $\begin{array}{l}<50 \\
<50 \\
<50 \\
<50 \\
<50\end{array}$ & $\begin{array}{l}<10 \\
<10 \\
<10 \\
<10 \\
<10\end{array}$ & $\begin{array}{l}<0.02 \\
<0.02 \\
<0.02 \\
<0.02 \\
<0.02\end{array}$ \\
\hline $\begin{array}{ll}\text { S } & 74295 \\
\text { S } & 74301 \\
\text { S } & 74307 \\
\text { S } & 86583 \\
\text { S } & 86584\end{array}$ & $\begin{array}{l}<50 \\
<50 \\
<50 \\
<50 \\
<50\end{array}$ & $\begin{array}{l}<50 \\
<50 \\
<50 \\
<50 \\
<50\end{array}$ & $\begin{array}{l}<200 \\
<200 \\
<200 \\
<200 \\
<200\end{array}$ & $\begin{array}{l}10 \\
10 \\
10 \\
10 \\
30\end{array}$ & $\begin{array}{l}<1 \\
<1 \\
<1 \\
<1 \\
<1\end{array}$ & $\begin{array}{l}<10 \\
<10 \\
<10 \\
<10 \\
<10\end{array}$ & $\begin{array}{l}<50 \\
<50 \\
<50 \\
<50 \\
<50\end{array}$ & $\begin{array}{l}<10 \\
<10 \\
<10 \\
<10 \\
<10\end{array}$ & $\begin{array}{l}<0.02 \\
<0.02 \\
<0.02 \\
<0.02 \\
<0.02\end{array}$ \\
\hline
\end{tabular}

1 The following constituents had no detections above detection limit in network wells (detection limit in parentheses): Arsenic (5 ug/L), Mercury $(0.5 \mathrm{ug} / \mathrm{L})$, Selenium $(5 \mathrm{ug} / \mathrm{L})$, and Silver $(50 \mathrm{ug} / \mathrm{L})$. 


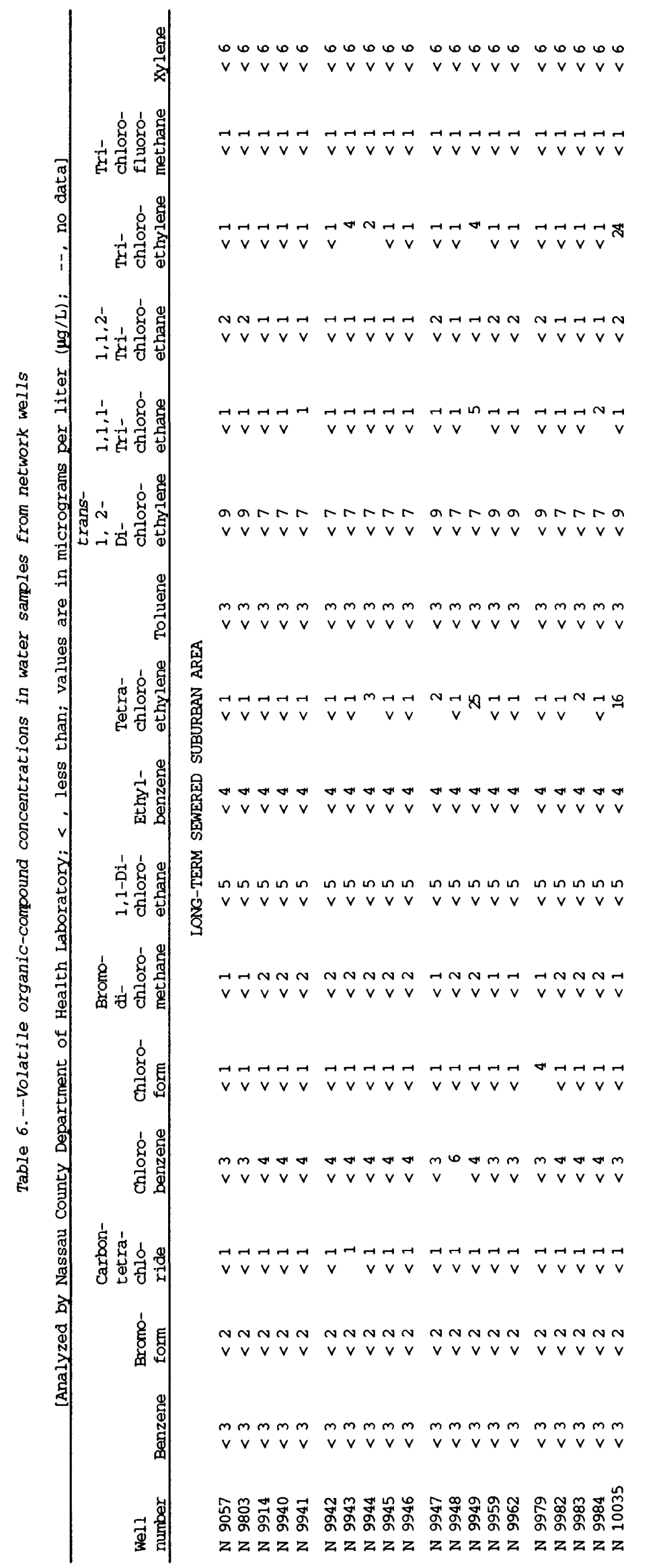

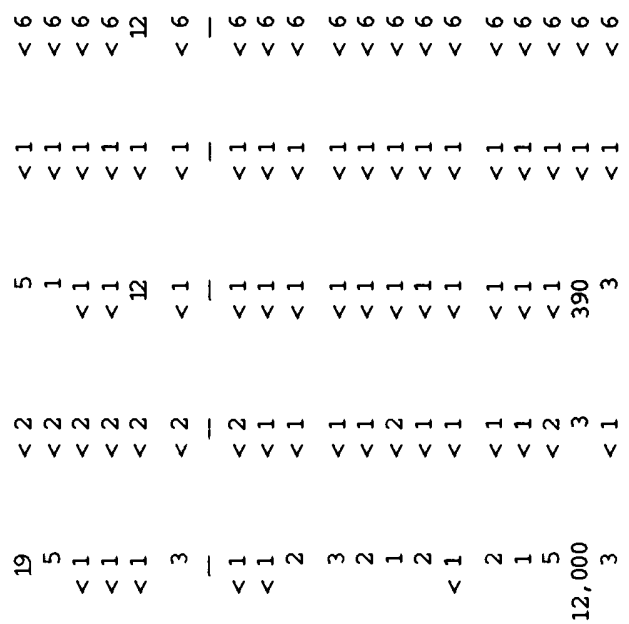




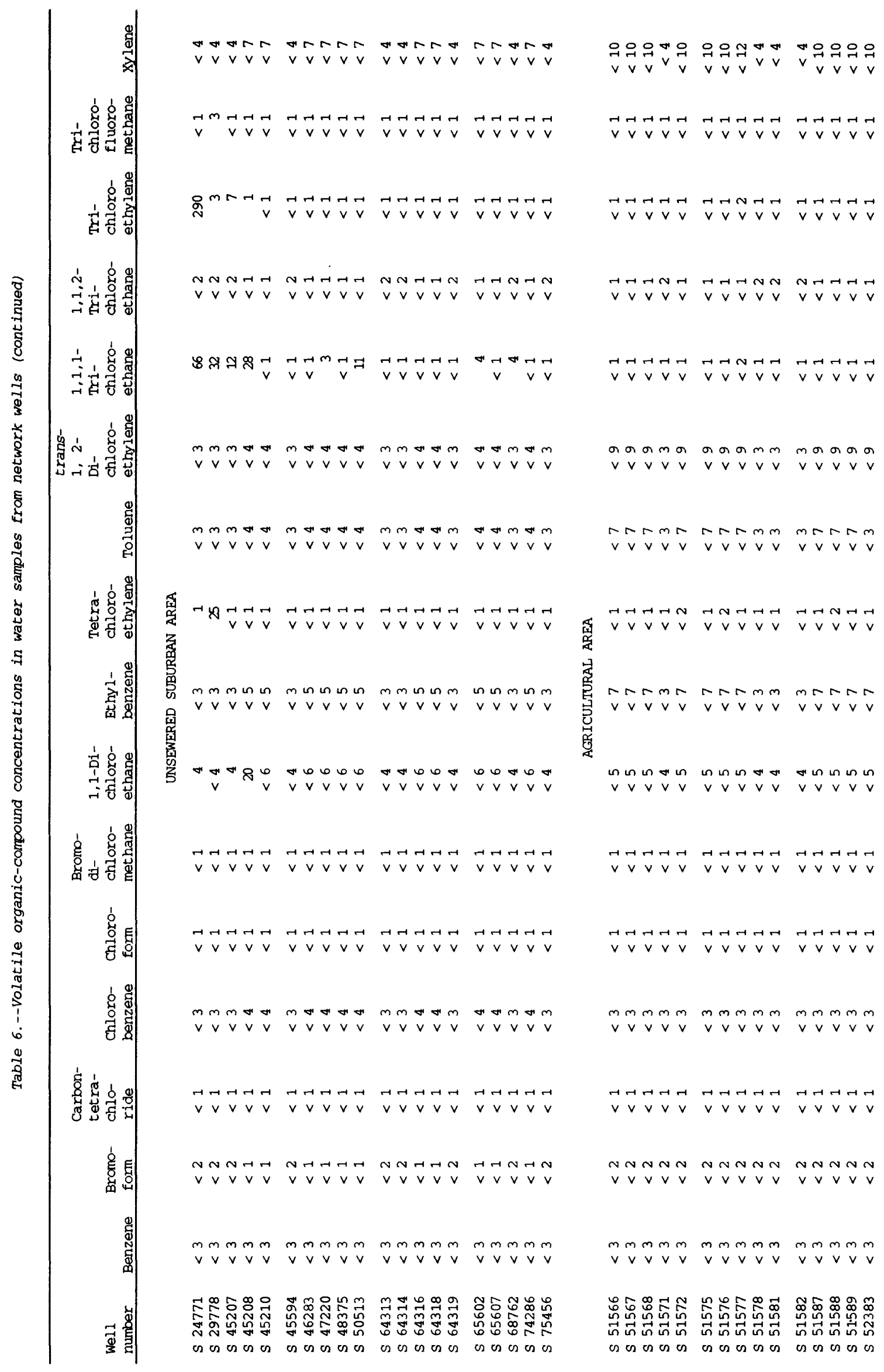




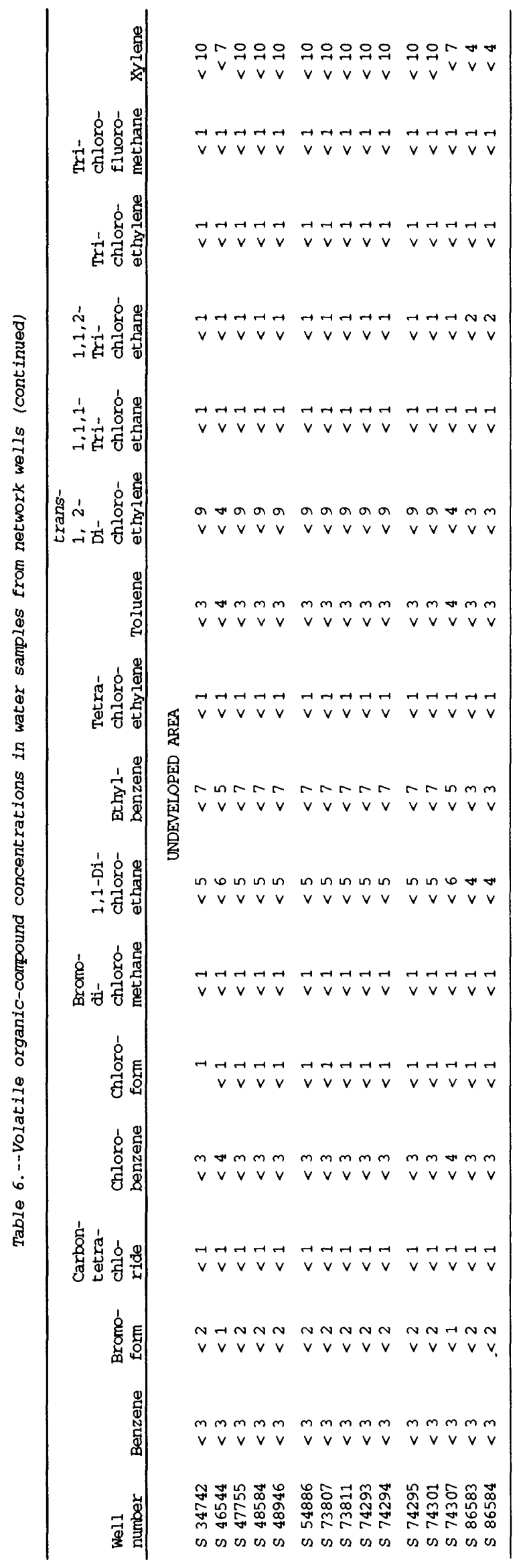


Table 7A.--Volatile organic compound concentrations in duplicate water samples from 13 network wells

[Analyzed by the National Water Quality Laboratory; Values are in micrograms per liter $(\mu \mathrm{g} / \mathrm{L})$, < less than]

\begin{tabular}{|c|c|c|c|c|c|c|c|c|c|c|}
\hline $\begin{array}{l}\text { Well } \\
\text { number }\end{array}$ & Benzene & $\begin{array}{l}\text { Chloro- } \\
\text { form }\end{array}$ & $\begin{array}{l}1,1- \\
\text { Di- } \\
\text { chloro } \\
\text { ethane }\end{array}$ & $\begin{array}{l}1,2 \text { - } \\
\text { Di- } \\
\text { chloro } \\
\text { ethane }\end{array}$ & $\begin{array}{l}1,1- \\
\text { Di- } \\
\text { chloro } \\
\text { ethy- } \\
\text { lene } \\
\end{array}$ & $\begin{array}{l}\text { Tetra- } \\
\text { chloro } \\
\text { ethy- } \\
\text { lene }\end{array}$ & $\begin{array}{l}\text { trans- } \\
1,2- \\
\text { Di- } \\
\text { chloro } \\
\text { ethy- } \\
\text { lene }\end{array}$ & $\begin{array}{l}1,1,1- \\
\text { Tri- } \\
\text { chloro } \\
\text { ethane }\end{array}$ & $\begin{array}{l}1,1,2 \\
\text { Tri- } \\
\text { chloro } \\
\text { ethane }\end{array}$ & $\begin{array}{l}\text { Tri- } \\
\text { chloro } \\
\text { ethy- } \\
\text { lene }\end{array}$ \\
\hline \multicolumn{11}{|c|}{ LONG-TERM SEWERED SUBURBAN AREA } \\
\hline N 9803 & $<0.2$ & 0.2 & $<0.2$ & $<0.2$ & $<0.2$ & $<0.2$ & $<0.2$ & 0.6 & $<0.2$ & $<0.2$ \\
\hline N 9940 & $<.2$ & 4.1 & $<.2$ & $<.2$ & $<.2$ & $<.2$ & $<.2$ & 1.5 & $<.2$ & $<.2$ \\
\hline N 9941 & $<.2$ & 4.3 & 2.5 & $<.2$ & $<.2$ & .5 & $<.2$ & 2.9 & $<.2$ & $<.2$ \\
\hline N 9982 & $<.2$ & .3 & $<.2$ & $<.2$ & $<.2$ & 1.6 & .2 & $<.2$ & $<.2$ & .5 \\
\hline $\mathrm{N} 10035$ & $<.2$ & .5 & $<.2$ & $<.2$ & $<.2$ & 8.6 & 2.4 & .4 & $<.2$ & 17 \\
\hline \multicolumn{11}{|c|}{ RECENTLY SEWERED SUBURBAN AREA } \\
\hline N 8888 & $<.2$ & 1.0 & 1.0 & $<.2$ & $<.2$ & 1.4 & $<.2$ & 3.4 & $<.2$ & .9 \\
\hline N 9354 & $<.2$ & $<.2$ & $<.2$ & $<.2$ & $<.2$ & .3 & $<.2$ & .7 & $<.2$ & .3 \\
\hline N 9924 & .4 & .3 & $<.2$ & $<.2$ & $<.2$ & .7 & $<.2$ & 1.0 & $<.2$ & .2 \\
\hline \multicolumn{11}{|c|}{ UNSEWERED SUBURBAN AREA } \\
\hline s24771 & $<.2$ & $<.2$ & 2.0 & $<.2$ & 8.3 & 1.6 & 2.2 & 85 & 1.8 & 120 \\
\hline s29778 & $<.2$ & .9 & 3.8 & $<.2$ & 5.4 & 23 & 2.4 & 44 & $<.2$ & 3.1 \\
\hline$S 45207$ & $<.2$ & 2.2 & 7.2 & .5 & 3.4 & .7 & $<.2$ & 13 & $<.2$ & 7.4 \\
\hline$S 46283$ & $<.2$ & $<.2$ & $<.2$ & $<.2$ & $<.2$ & $<.2$ & $<.2$ & $<.2$ & $<.2$ & $<.2$ \\
\hline S64314 & $<.2$ & 2.3 & $<.2$ & $<.2$ & $<.2$ & $<.2$ & $<.2$ & $<.2$ & $<.2$ & $<.2$ \\
\hline
\end{tabular}

Table 7B.--Volatile organic compounds not detected in duplicate water samples from 13 network wells

[Analyzed by National Water Quality Laboratory; Detection limit for all constituents $=0.2 \mu \mathrm{g} / \mathrm{L}$ ]

\begin{tabular}{ll}
\hline 1,1,2,2-Tetrachloroethane & Chlorodibromomethane \\
1,2-Dibromoethene (EDB) & Chloroethane \\
1,2-Dichlorobenzene & Dichlorodiflouromethane \\
1,2-Dichloropropane & Ethylbenzene \\
1,3-Dichlorobenzene & Methyl bromide \\
1,3-Dichloropropane & Methyl chloride \\
1,4-Dichlorobenzene & Methylene chloride \\
2-Chloroethyl vinyl ether & Styrene \\
Bromodichloromethane & Toluene \\
Bromoform & Vinyl chloride \\
Carbon tetrachloride & Xylene \\
Chlorobenzene & Cis-1,3-Dichloropropene \\
\hline
\end{tabular}


Table 8.--Organochlorine insecticide concentrations in water samples from network wells

[Values are in micrograms per liter (ug/L); all values are totals; $<$, less than; --, no data]

\begin{tabular}{|c|c|c|c|c|c|c|c|c|c|c|}
\hline $\begin{array}{l}\text { Well } \\
\text { number }\end{array}$ & $\begin{array}{c}\text { Chlor- } \\
\text { dane }\end{array}$ & DDD & DDE & DDT & $\begin{array}{c}\text { Diel- } \\
\text { drin }\end{array}$ & $\begin{array}{l}\text { Endo- } \\
\text { sulfan }\end{array}$ & $\begin{array}{l}\text { Hepta- } \\
\text { chlor } \\
\text { epoxide }\end{array}$ & Lindane & $\begin{array}{c}\text { Meth- } \\
\text { oxy- } \\
\text { chlor }\end{array}$ & $\begin{array}{l}\text { Per } \\
\text { than }\end{array}$ \\
\hline \multicolumn{11}{|c|}{ LONG-TERM SEWERED SUBURBAN AREA } \\
\hline N 9057 & 0.7 & $<0.01$ & $<0.01$ & $<0.01$ & 0.16 & $<0.01$ & 0.15 & $<0.01$ & $<0.01$ & $<0.1$ \\
\hline N 9803 & $<.1$ & $<.01$ & $<.01$ & $<.01$ & $<.01$ & $<.01$ & $<.01$ & $<.01$ & $<.01$ & $<.1$ \\
\hline N 9914 & .4 & $<.01$ & $<.01$ & $<.01$ & $<.01$ & $<.01$ & $<.01$ & $<.01$ & $<.01$ & $<.1$ \\
\hline N 9940 & $<.1$ & $<.01$ & $<.01$ & $<.01$ & .04 & $<.01$ & .01 & $<.01$ & $<.01$ & $<.1$ \\
\hline N 9941 & $<.1$ & $<.01$ & $<.01$ & $<.01$ & .14 & $<.01$ & $<.01$ & $<.01$ & $<.01$ & $<.1$ \\
\hline N 9942 & .4 & $<.01$ & $<.01$ & $<.01$ & .39 & $<.01$ & $<.01$ & $<.01$ & $<.01$ & $<$. \\
\hline N 9943 & $<.1$ & $<.01$ & $<.01$ & $<.01$ & $<.01$ & $<.01$ & $<.01$ & $<.01$ & $<.01$ & $<$ \\
\hline N 9944 & $<.1$ & $<.01$ & $<.01$ & $<.01$ & .03 & $<.01$ & $<.01$ & $<.01$ & $<.01$ & $<$ \\
\hline N 9945 & $<.1$ & $<.01$ & $<.01$ & $<.01$ & .05 & $<.01$ & .02 & $<.01$ & $<.01$ & $<$. \\
\hline N 9946 & $<.1$ & $<.01$ & $<.01$ & $<.01$ & $<.01$ & $<.01$ & $<.01$ & $<.01$ & $<.01$ & $<.1$ \\
\hline N 9947 & $<.1$ & $<.01$ & $<.01$ & $<.01$ & $<.01$ & $<.01$ & $<.01$ & $<.01$ & $<.01$ & $<$ \\
\hline N 9948 & $<.1$ & $<.01$ & $<.01$ & $<.01$ & $<.01$ & $<.01$ & $<.01$ & $<.01$ & $<.01$ & $<$ \\
\hline N 9949 & $<.1$ & $<.01$ & $<.01$ & $<.01$ & $<.01$ & $<.01$ & $<.01$ & $<.01$ & $<.01$ & $<$ \\
\hline N 9959 & $<.1$ & $<.01$ & $<.01$ & $<.01$ & $<.01$ & $<.01$ & $<.01$ & $<.01$ & $<.01$ & $<$ \\
\hline N 9962 & 1.3 & $<.01$ & $<.01$ & $<.01$ & $<.01$ & $<.01$ & $<.01$ & $<.01$ & $<.01$ & $<.1$ \\
\hline N 9979 & $<.1$ & $<.01$ & $<.01$ & $<.01$ & $<.01$ & $<.01$ & $<.01$ & $<.01$ & $<.01$ & $<$ \\
\hline N 9982 & $<.1$ & $<.01$ & $<.01$ & $<.01$ & .01 & $<.01$ & $<.01$ & $<.01$ & $<.01$ & $<$ \\
\hline N 9983 & $<.1$ & $<.01$ & $<.01$ & $<.01$ & $<.01$ & $<.01$ & $<.01$ & $<.01$ & $<.01$ & $<$. \\
\hline N 9984 & $<.1$ & $<.01$ & $<.01$ & $<.01$ & $<.01$ & $<.01$ & .03 & $<.01$ & $<.01$ & $<$. \\
\hline N 10035 & $<.1$ & $<.01$ & $<.01$ & $<.01$ & $<.01$ & $<.01$ & $<.01$ & $<.01$ & $<.01$ & $<$. \\
\hline
\end{tabular}

RECENTLY SEWERED SUBURBAN AREA

\begin{tabular}{|c|c|c|c|c|c|c|c|c|c|c|c|}
\hline $\mathrm{N}$ & 1197 & .3 & $<.01$ & $<.01$ & $<.01$ & .14 & $<.01$ & $<.01$ & $<.01$ & $<.01$ & $<.1$ \\
\hline $\mathrm{N}$ & 8888 & .2 & $<.01$ & $<.01$ & $<.01$ & .05 & $<.01$ & $<.01$ & $<.01$ & $<.01$ & $<.1$ \\
\hline $\mathrm{N}$ & 8984 & .1 & $<.01$ & $<.01$ & $<.01$ & .03 & $<.01$ & $<.01$ & $<.01$ & $<.01$ & $<.1$ \\
\hline $\mathrm{N}$ & 9078 & $<.1$ & $<.01$ & $<.01$ & $<.01$ & $<.01$ & $<.01$ & $<.01$ & $<.01$ & $<.01$ & $<.1$ \\
\hline $\mathrm{N}$ & 9079 & $<.1$ & $<.01$ & $<.01$ & $<.01$ & .17 & $<.01$ & $<.01$ & $<.01$ & $<.01$ & $<.1$ \\
\hline $\mathrm{N}$ & 9222 & .2 & $<.01$ & $<.01$ & $<.01$ & .10 & $<.01$ & $<.01$ & $<.01$ & $<.01$ & $<.1$ \\
\hline $\mathrm{N}$ & 9354 & .3 & $<.01$ & $<.01$ & $<.01$ & .13 & $<.01$ & $<.01$ & $<.01$ & $<.01$ & $<.1$ \\
\hline $\mathrm{N}$ & 9451 & 1.3 & $<.01$ & $<.01$ & $<.01$ & .73 & $<.01$ & $<.01$ & $<.01$ & $<.01$ & $<.1$ \\
\hline $\mathrm{N}$ & 9917 & $<.1$ & $<.01$ & $<.01$ & $<.01$ & $<.01$ & $<.01$ & $<.01$ & $<.01$ & $<.01$ & $<.1$ \\
\hline $\mathrm{N}$ & 9918 & $<.1$ & $<.01$ & $<.01$ & $<.01$ & .06 & $<.01$ & .01 & $<.01$ & $<.01$ & $<.1$ \\
\hline $\mathrm{N}$ & 9919 & .2 & $<.01$ & $<.01$ & $<.01$ & .02 & $<.01$ & $<.01$ & $<.01$ & $<.01$ & $<.1$ \\
\hline $\mathrm{N}$ & 9920 & $<.1$ & $<.01$ & $<.01$ & $<.01$ & $<.01$ & $<.01$ & $<.01$ & $<.01$ & $<.01$ & $<.1$ \\
\hline $\mathrm{N}$ & 9924 & .1 & $<.01$ & $<.01$ & $<.01$ & .04 & $<.01$ & $<.01$ & $<.01$ & $<.01$ & $<.1$ \\
\hline $\mathrm{N}$ & 9925 & .5 & $<.01$ & $<.01$ & $<.01$ & .09 & $<.01$ & .03 & $<.01$ & $<.01$ & $<.1$ \\
\hline $\mathrm{N}$ & 9926 & $<.1$ & $<.01$ & $<.01$ & $<.01$ & .02 & $<.01$ & .01 & $<.01$ & $<.01$ & $<.1$ \\
\hline $\mathrm{N}$ & 9927 & .4 & $<.01$ & $<.01$ & $<.01$ & .07 & $<.01$ & .27 & $<.01$ & $<.01$ & $<.1$ \\
\hline $\mathrm{N}$ & 9928 & $<.1$ & $<.01$ & $<.01$ & $<.01$ & .05 & $<.01$ & $<.04$ & $<.01$ & $<.01$ & $<.1$ \\
\hline $\mathrm{N}$ & 9933 & 1.1 & $<.01$ & $<.01$ & $<.01$ & .18 & $<.01$ & $<.01$ & $<.01$ & $<.01$ & $<.1$ \\
\hline $\mathrm{N}$ & 9938 & $<.1$ & $<.01$ & $<.01$ & $<.01$ & $<.01$ & $<.01$ & $<.01$ & $<.01$ & $<.01$ & $<.1$ \\
\hline \multirow[t]{2}{*}{$\mathrm{N}$} & 9939 & .2 & $<.01$ & $<.01$ & $<.01$ & .30 & $<.01$ & .09 & $<.01$ & $<.01$ & $<.1$ \\
\hline & & & & & UNSEWERED & SUBURBAN & A AREA & & & & \\
\hline$S$ & 24771 & $<.1$ & $<.01$ & $<.01$ & $<.01$ & $<.01$ & $<.01$ & $<.01$ & $<.01$ & $<.01$ & $<.1$ \\
\hline S & 29778 & $<.1$ & $<.01$ & $<.01$ & $<.01$ & $<.01$ & $<.01$ & $<.01$ & $<.01$ & $<.01$ & $<.1$ \\
\hline S & 45207 & $<.1$ & $<.01$ & $<.01$ & $<.01$ & $<.01$ & $<.01$ & $<.01$ & $<.01$ & $<.01$ & $<.1$ \\
\hline S & 45208 & .3 & $<.01$ & $<.01$ & $<.01$ & .38 & $<.01$ & $<.01$ & -- & $<.01$ & $<.1$ \\
\hline$S$ & 45210 & $<.1$ & $<.01$ & $<.01$ & $<.01$ & $<.01$ & $<.01$ & $<.01$ & $<.01$ & $<.01$ & $<.1$ \\
\hline
\end{tabular}


Table 8.--Organochlorine insecticide concentrations in water samples from network wells (continued)

\begin{tabular}{|c|c|c|c|c|c|c|c|c|c|c|}
\hline $\begin{array}{l}\text { Well } \\
\text { number }\end{array}$ & $\begin{array}{c}\text { Chlor- } \\
\text { dane }\end{array}$ & $\mathrm{DDD}$ & DDE & $\mathrm{DDT}$ & $\begin{array}{c}\text { Diel- } \\
\text { drin }\end{array}$ & $\begin{array}{l}\text { Endo- } \\
\text { sulfan }\end{array}$ & $\begin{array}{l}\text { Hepta- } \\
\text { chlor } \\
\text { epoxide }\end{array}$ & Lindane & $\begin{array}{c}\text { Meth- } \\
\text { oxy- } \\
\text { chlor }\end{array}$ & $\begin{array}{l}\text { Per- } \\
\text { thane }\end{array}$ \\
\hline \multicolumn{11}{|c|}{ UNSEWERED SUBURBAN AREA (cont' $d$ ) } \\
\hline S 45594 & $<.1$ & $<.01$ & $<.01$ & $<.01$ & $<.01$ & $<.01$ & $<.01$ & $<.01$ & $<.01$ & $<.1$ \\
\hline S 46283 & $<.1$ & $<.01$ & $<.01$ & $<.01$ & $<.01$ & $<.01$ & $<.01$ & $<.01$ & $<.01$ & $<.1$ \\
\hline S 47220 & $<.1$ & $<.01$ & $<.01$ & $<.01$ & $<.01$ & $<.01$ & $<.01$ & $<.01$ & $<.01$ & $<.1$ \\
\hline S 48375 & $<.1$ & $<.01$ & $<.01$ & $<.01$ & $<.01$ & $<.01$ & $<.01$ & $<.01$ & $<.01$ & $<.1$ \\
\hline S 50513 & .1 & $<.01$ & $<.01$ & $<.01$ & .01 & $<.01$ & $<.01$ & $<.01$ & $<.01$ & $<.1$ \\
\hline S 64313 & $<.1$ & $<.01$ & $<.01$ & $<.01$ & $<.01$ & $<.01$ & $<.01$ & $<.01$ & $<.01$ & $<.1$ \\
\hline S 64314 & $<.1$ & $<.01$ & $<.01$ & $<.01$ & $<.01$ & $<.01$ & $<.01$ & $<.01$ & $<.01$ & $<.1$ \\
\hline S 64316 & $<.1$ & $<.01$ & $<.01$ & $<.01$ & $<.01$ & $<.01$ & $<.01$ & $<.01$ & $<.01$ & $<.1$ \\
\hline S 64318 & $<.1$ & $<.01$ & $<.01$ & $<.01$ & $<.01$ & $<.01$ & $<.01$ & $<.01$ & $<.01$ & $<.1$ \\
\hline S 64319 & $<.1$ & $<.01$ & $<.01$ & $<.01$ & $<.01$ & $<.01$ & $<.01$ & $<.01$ & $<.01$ & $<.1$ \\
\hline S 65602 & $<.1$ & $<.01$ & $<.01$ & $<.01$ & .05 & $<.01$ & .03 & $<.01$ & $<.01$ & $<.1$ \\
\hline S 65607 & .1 & $<.01$ & $<.01$ & $<.01$ & $<.01$ & $<.01$ & $<.01$ & $<.01$ & $<.01$ & $<.1$ \\
\hline S 68762 & $<.1$ & $<.01$ & $<.01$ & $<.01$ & .03 & $<.01$ & $<.01$ & $<.01$ & $<.01$ & $<.1$ \\
\hline S 74286 & $<.1$ & $<.01$ & $<.01$ & $<.01$ & $<.01$ & $<.01$ & $<.01$ & $<.01$ & $<.01$ & $<.1$ \\
\hline S 75456 & $<.1$ & $<.01$ & $<.01$ & $<.01$ & $<.01$ & $<.01$ & $<.01$ & $<.01$ & $<.01$ & $<.1$ \\
\hline \multicolumn{11}{|c|}{ AGRICULTURAL AREA } \\
\hline S 51566 & $<.1$ & $<.01$ & .01 & $<.01$ & $<.01$ & .01 & .01 & $<.01$ & $<.01$ & $<.1$ \\
\hline S 51567 & $<.1$ & $<.01$ & $<.01$ & $<.01$ & $<.01$ & $<.01$ & .01 & $<.01$ & $<.01$ & $<.1$ \\
\hline S 51568 & $<.1$ & .01 & $<.01$ & $<.01$ & .01 & .08 & $<.01$ & $<.01$ & $<.01$ & $<.1$ \\
\hline S 51571 & $<.1$ & $<.01$ & $<.01$ & $<.01$ & $<.01$ & $<.01$ & .01 & $<.01$ & $<.01$ & $<.1$ \\
\hline S 51572 & $<.1$ & $<.01$ & $<.01$ & $<.01$ & .01 & .04 & $<.01$ & .04 & $<.01$ & .1 \\
\hline S 51575 & $<.1$ & .25 & $<.01$ & $<.01$ & $<.01$ & $<.01$ & $<.01$ & $<.01$ & $<.01$ & $<.1$ \\
\hline S 51576 & -- & -- & -- & -- & -- & -- & -- & -- & -- & -- \\
\hline S 51577 & $<.1$ & $<.01$ & $<.01$ & $<.01$ & $<.01$ & $<.01$ & .01 & $<.01$ & $<.01$ & $<.1$ \\
\hline S 51578 & $<.1$ & $<.01$ & $<.01$ & $<.01$ & $<.01$ & $<.01$ & .01 & $<.01$ & $<.01$ & $<.1$ \\
\hline S 51581 & $<.1$ & $<.01$ & $<.01$ & $<.01$ & $<.01$ & $<.01$ & .01 & $<.01$ & $<.01$ & $<.1$ \\
\hline S 51582 & $<.1$ & .02 & .01 & $<.01$ & $<.01$ & $<.01$ & $<.01$ & $<.01$ & .01 & $<.1$ \\
\hline S 51587 & $<.1$ & .01 & .01 & .02 & $<.01$ & $<.01$ & $<.01$ & $<.01$ & .02 & $<.1$ \\
\hline S 51588 & $<.1$ & .02 & $<.01$ & $<.01$ & .01 & 1.10 & $<.01$ & .01 & $<.01$ & $<.1$ \\
\hline S 51589 & $<.1$ & $<.01$ & $<.01$ & $<.01$ & .02 & .44 & $<.01$ & $<.01$ & $<.01$ & $<.1$ \\
\hline S 52383 & $<.1$ & $<.01$ & $<.01$ & $<.01$ & .01 & $<.01$ & .01 & $<.01$ & $<.01$ & $<.1$ \\
\hline \multicolumn{11}{|c|}{ UNDEVELOPED AREA } \\
\hline S 34742 & $<.1$ & $<.01$ & $<.01$ & $<.01$ & $<.01$ & $<.01$ & $<.01$ & $<.01$ & $<.01$ & $<.1$ \\
\hline S 46544 & $<.1$ & $<.01$ & $<.01$ & $<.01$ & $<.01$ & $<.01$ & $<.01$ & $<.01$ & $<.01$ & $<.1$ \\
\hline S 47755 & $<.1$ & $<.01$ & $<.01$ & $<.01$ & $<.01$ & $<.01$ & $<.01$ & $<.01$ & $<.01$ & $<.1$ \\
\hline S 48584 & $<.1$ & $<.01$ & $<.01$ & $<.01$ & $<.01$ & $<.01$ & $<.01$ & $<.01$ & $<.01$ & $<.1$ \\
\hline S 48946 & $<.1$ & $<.01$ & $<.01$ & $<.01$ & $<.01$ & .03 & $<.01$ & $<.01$ & $<.01$ & $<.1$ \\
\hline S 54886 & $<.1$ & $<.01$ & $<.01$ & $<.01$ & $<.01$ & $<.01$ & $<.01$ & $<.01$ & $<.01$ & $<.1$ \\
\hline S 73807 & $<.1$ & $<.01$ & $<.01$ & $<.01$ & $<.01$ & $<.01$ & $<.01$ & $<.01$ & $<.01$ & $<.1$ \\
\hline S 73811 & $<.1$ & $<.01$ & $<.01$ & $<.01$ & $<.01$ & $<.01$ & $<.01$ & $<.01$ & $<.01$ & $<.1$ \\
\hline S 74293 & $<.1$ & $<.01$ & $<.01$ & $<.01$ & $<.01$ & $<.01$ & $<.01$ & $<.01$ & $<.01$ & $<.1$ \\
\hline S 74294 & $<.1$ & $<.01$ & $<.01$ & $<.01$ & $<.01$ & $<.01$ & $<.01$ & $<.01$ & $<.01$ & $<.1$ \\
\hline S 74295 & $<.1$ & $<.01$ & $<.01$ & $<.01$ & $<.01$ & $<.01$ & $<.01$ & $<.01$ & $<.01$ & $<.1$ \\
\hline S 74301 & $<.1$ & $<.01$ & $<.01$ & $<.01$ & $<.01$ & $<.01$ & $<.01$ & $<.01$ & $<.01$ & $<.1$ \\
\hline S 74307 & $<.1$ & $<.01$ & $<.01$ & $<.01$ & $<.01$ & $<.01$ & $<.01$ & $<.01$ & $<.01$ & $<.1$ \\
\hline S 86583 & $<.1$ & $<.01$ & $<.01$ & $<.01$ & $<.01$ & $<.01$ & $<.01$ & $<.01$ & $<.01$ & $<.1$ \\
\hline S 86584 & $<.1$ & $<.01$ & $<.01$ & $<.01$ & $<.01$ & $<.01$ & $<.01$ & $<.01$ & $<.01$ & $<.1$ \\
\hline
\end{tabular}


Table 9A.--Chlorophenoxy-acid herbicide, triazine herbicide, and organophosphorus insecticide concentrations in water samples from network wells

[Values are in micrograms per liter $(\mathrm{ug} / \mathrm{L}) ;<$, less than; --, no data]

\begin{tabular}{|c|c|c|c|c|c|c|c|}
\hline \multirow[b]{2}{*}{ Well number } & \multicolumn{2}{|c|}{$\begin{array}{c}\text { Chlorophenoxy acid } \\
\text { herbicides }\end{array}$} & \multicolumn{3}{|c|}{ Triazine herbicides } & \multicolumn{2}{|c|}{$\begin{array}{l}\text { Organophosphorus } \\
\text { insecticides }\end{array}$} \\
\hline & $2,4-D$ & Silvex & Atrazine & Prometone & Simazine & Diazinon & Ethion \\
\hline \multicolumn{8}{|c|}{ LONG-TERM SEWERED SUBURBAN AREA } \\
\hline N 9057 & $<0.01$ & $<0.01$ & $<0.1$ & $<0.1$ & 0.1 & $<0.01$ & $<0.01$ \\
\hline N 9803 & $<0.01$ & $<0.01$ & $<0.1$ & $<0.1$ & $<0.1$ & $<0.01$ & $<0.01$ \\
\hline N 9914 & $<0.01$ & $<0.01$ & $<0.1$ & $<0.1$ & $<0.1$ & $<0.01$ & $<0.01$ \\
\hline N 9940 & $<0.01$ & $<0.01$ & $<0.1$ & $<0.1$ & $<0.1$ & $<0.01$ & $<0.01$ \\
\hline N 9941 & $<0.01$ & $<0.01$ & $<0.1$ & $<0.1$ & 0.1 & $<0.01$ & $<0.01$ \\
\hline N 9942 & $<0.01$ & $<0.01$ & $<0.1$ & $<0.1$ & $<0.1$ & $<0.01$ & $<0.01$ \\
\hline N 9943 & $<0.01$ & $<0.01$ & 0.7 & $<0.1$ & $<0.1$ & $<0.01$ & $<0.01$ \\
\hline N 9944 & $<0.01$ & $<0.01$ & $<0.1$ & $<0.1$ & $<0.1$ & $<0.01$ & $<0.01$ \\
\hline N 9945 & $<0.01$ & $<0.01$ & $<0.1$ & $<0.1$ & $<0.1$ & $<0.01$ & $<0.01$ \\
\hline N 9946 & $<0.01$ & $<0.01$ & $<0.1$ & $<0.1$ & $<0.1$ & $<0.01$ & $<0.01$ \\
\hline N 9947 & $<0.01$ & $<0.01$ & $<0.1$ & $<0.1$ & $<0.1$ & $<0.01$ & $<0.01$ \\
\hline N 9948 & $<0.01$ & $<0.01$ & $<0.1$ & $<0.1$ & $<0.1$ & -- & -- \\
\hline N 9949 & $<0.01$ & $<0.01$ & $<0.1$ & $<0.1$ & $<0.1$ & $<0.01$ & $<0.01$ \\
\hline N 9959 & 0.02 & 0.01 & $<0.1$ & $<0.1$ & $<0.1$ & $<0.01$ & $<0.01$ \\
\hline N 9962 & $<0.01$ & $<0.01$ & 0.2 & $<0.1$ & 9.6 & $<0.01$ & $<0.01$ \\
\hline N 9979 & $<0.01$ & $<0.01$ & $<0.1$ & $<0.1$ & $<0.1$ & $<0.01$ & $<0.01$ \\
\hline N 9982 & $<0.01$ & $<0.01$ & $<0.1$ & $<0.1$ & $<0.1$ & $<0.01$ & $<0.01$ \\
\hline N 9983 & $<0.01$ & $<0.01$ & $<0.1$ & $<0.1$ & $<0.1$ & -- & -- \\
\hline N 9984 & $<0.01$ & $<0.01$ & $<0.1$ & $<0.1$ & $<0.1$ & $<0.01$ & $<0.01$ \\
\hline N 10035 & $<0.01$ & $<0.01$ & $<0.1$ & $<0.1$ & 0.1 & $<0.01$ & $<0.01$ \\
\hline \multicolumn{8}{|c|}{ RECENTLY SEWERED SUBURBAN AREA } \\
\hline N 1197 & $<0.01$ & $<0.01$ & $<0.1$ & $<0.1$ & $<0.1$ & $<0.01$ & $<0.01$ \\
\hline N 8888 & $<0.01$ & $<0.01$ & $<0.1$ & $<0.1$ & $<0.1$ & $<0.01$ & $<0.01$ \\
\hline N 8984 & $<0.01$ & $<0.01$ & $<0.1$ & 0.1 & $<0.1$ & 0.05 & $<0.01$ \\
\hline N 9078 & $<0.01$ & $<0.01$ & $<0.1$ & $<0.1$ & 1.3 & $<0.01$ & $<0.01$ \\
\hline N 9079 & $<0.01$ & $<0.01$ & $<0.1$ & $<0.1$ & $<0.1$ & $<0.01$ & $<0.01$ \\
\hline N 9222 & $<0.01$ & $<0.01$ & $<0.1$ & $<0.1$ & 0.1 & $<0.01$ & $<0.01$ \\
\hline N 9354 & $<0.01$ & $<0.01$ & $<0.1$ & $<0.1$ & $<0.1$ & $<0.01$ & $<0.01$ \\
\hline N 9451 & $<0.01$ & $<0.01$ & $<0.1$ & $<0.1$ & $<0.1$ & $<0.01$ & $<0.01$ \\
\hline N 9917 & 0.03 & $<0.01$ & $<0.1$ & $<0.1$ & 0.1 & $<0.01$ & $<0.01$ \\
\hline N 9918 & $<0.01$ & $<0.01$ & $<0.1$ & $<0.1$ & $<0.1$ & $<0.01$ & $<0.01$ \\
\hline N 9919 & $<0.01$ & $<0.01$ & 0.1 & $<0.1$ & 0.2 & $<0.01$ & $<0.01$ \\
\hline N 9920 & -- & -- & $<0.1$ & $<0.1$ & $<0.1$ & $<0.01$ & $<0.01$ \\
\hline N 9924 & $<0.01$ & $<0.01$ & $<0.1$ & $<0.1$ & $<0.1$ & $<0.01$ & $<0.01$ \\
\hline N 9925 & $<0.01$ & $<0.01$ & $<0.1$ & $<0.1$ & $<0.1$ & $<0.01$ & $<0.01$ \\
\hline N 9926 & -- & - & $<0.1$ & $<0.1$ & $<0.1$ & $<0.01$ & $<0.01$ \\
\hline N 9927 & $<0.01$ & $<0.01$ & $<0.1$ & $<0.1$ & $<0.1$ & $<0.01$ & $<0.01$ \\
\hline N 9928 & $<0.01$ & $<0.01$ & $<0.1$ & $<0.1$ & $<0.1$ & $<0.01$ & $<0.01$ \\
\hline N 9933 & $<0.01$ & $<0.01$ & $<0.1$ & $<0.1$ & $<0.1$ & $<0.01$ & $<0.01$ \\
\hline N 9938 & $<0.01$ & $<0.01$ & $<0.1$ & $<0.1$ & $<0.1$ & $<0.01$ & $<0.01$ \\
\hline N 9939 & $<0.01$ & $<0.01$ & $<0.1$ & $<0.1$ & $<0.1$ & $<0.01$ & $<0.01$ \\
\hline \multicolumn{8}{|c|}{ UNSEWERED SUBURBAN AREA } \\
\hline S 24771 & $<0.01$ & $<0.01$ & $<0.1$ & $<0.1$ & $<0.1$ & $<0.01$ & $<0.01$ \\
\hline S 29778 & $<0.01$ & $<0.01$ & $<0.1$ & $<0.1$ & $<0.1$ & $<0.01$ & $<0.01$ \\
\hline S 45207 & $<0.01$ & $<0.01$ & $<0.1$ & $<0.1$ & $<0.1$ & $<0.01$ & $<0.01$ \\
\hline S 45208 & $<0.01$ & $<0.01$ & $<0.1$ & $<0.1$ & $<0.1$ & $<0.01$ & $<0.01$ \\
\hline S 45210 & $<0.01$ & $<0.01$ & $<0.1$ & $<0.1$ & $<0.1$ & $<0.01$ & $<0.01$ \\
\hline
\end{tabular}


Table 9A.--Chlorophenoxy-acid herbicide, triazine herbicide, and organophosphorus insecticide concentrations in water samples from network wells (continued)

\begin{tabular}{|c|c|c|c|c|c|c|c|c|}
\hline \multirow{2}{*}{\multicolumn{2}{|c|}{ Well number }} & \multicolumn{2}{|c|}{$\begin{array}{c}\text { Chlorophenoxy acid } \\
\text { herbicides }\end{array}$} & \multicolumn{3}{|c|}{ Triazine Herbicides } & \multicolumn{2}{|c|}{$\begin{array}{l}\text { Organophosphorus } \\
\text { insecticides }\end{array}$} \\
\hline & & $2,4-D$ & Silvex & Atrazine & Prometone & Simazine & Diazinon & Ethion \\
\hline \multicolumn{9}{|c|}{ UNSEWERED SUBURBAN AREA (cont'd) } \\
\hline$S$ & 45594 & $<0.01$ & $<0.01$ & $<0.1$ & $<0.1$ & $<0.1$ & $<0.01$ & $<0.01$ \\
\hline$S$ & 46283 & $<0.01$ & $<0.01$ & $<0.1$ & $<0.1$ & $<0.1$ & $<0.01$ & $<0.01$ \\
\hline $\mathrm{s}$ & 47220 & $<0.01$ & $<0.01$ & $<0.1$ & $<0.1$ & $<0.1$ & $<0.01$ & $<0.01$ \\
\hline S & 48375 & 0.01 & $<0.01$ & $<0.1$ & 0.1 & $<0.1$ & 0.08 & $<0.01$ \\
\hline & 50513 & $<0.01$ & $<0.01$ & $<0.1$ & $<0.1$ & $<0.1$ & $<0.01$ & $<0.01$ \\
\hline $\mathrm{S}$ & 64313 & $<0.01$ & $<0.01$ & $<0.1$ & 0.1 & 0.1 & 0.13 & $<0.01$ \\
\hline $\mathrm{S}$ & 64314 & $<0.01$ & $<0.01$ & $<0.1$ & $<0.1$ & $<0.1$ & $<0.01$ & $<0.01$ \\
\hline $\mathrm{S}$ & 64316 & $<0.01$ & $<0.01$ & 0.1 & $<0.1$ & $<0.1$ & $<0.01$ & $<0.01$ \\
\hline & 64318 & $<0.01$ & $<0.01$ & $<0.1$ & $<0.1$ & $<0.1$ & $<0.01$ & $<0.01$ \\
\hline & 64319 & $<0.01$ & $<0.01$ & $<0.1$ & $<0.1$ & $<0.1$ & $<0.01$ & $<0.01$ \\
\hline & 65602 & $<0.01$ & $<0.01$ & $<0.1$ & $<0.1$ & $<0.1$ & $<0.01$ & $<0.01$ \\
\hline & 65607 & $<0.01$ & $<0.01$ & $<0.1$ & $<0.1$ & $<0.1$ & $<0.01$ & $<0.01$ \\
\hline$S$ & 68762 & $<0.01$ & $<0.01$ & $<0.1$ & $<0.1$ & $<0.1$ & $<0.01$ & $<0.01$ \\
\hline $\mathrm{S}$ & 74286 & $<0.01$ & $<0.01$ & $<0.1$ & $<0.1$ & $<0.1$ & $<0.01$ & $<0.01$ \\
\hline & 75456 & $<0.01$ & $<0.01$ & $<0.1$ & $<0.1$ & $<0.1$ & $<0.01$ & $<0.01$ \\
\hline \multicolumn{9}{|c|}{ AGRICULTURAL AREA } \\
\hline S & 51566 & $<0.01$ & $<0.01$ & $<0.1$ & $<0.1$ & $<0.1$ & $<0.01$ & $<0.01$ \\
\hline & 51567 & $<0.01$ & $<0.01$ & $<0.1$ & $<0.1$ & $<0.1$ & $<0.01$ & $<0.01$ \\
\hline$S$ & 51568 & $<0.01$ & $<0.01$ & $<0.1$ & $<0.1$ & $<0.1$ & $<0.01$ & $<0.01$ \\
\hline$S$ & 51571 & $<0.01$ & $<0.01$ & $<0.1$ & $<0.1$ & $<0.1$ & $<0.01$ & $<0.01$ \\
\hline & 51572 & 0.15 & $<0.01$ & $<0.1$ & $<0.1$ & $<0.1$ & $<0.01$ & $<0.01$ \\
\hline$S$ & 51575 & $<0.01$ & $<0.01$ & $<0.1$ & $<0.1$ & $<0.1$ & $<0.01$ & $<0.01$ \\
\hline & 51576 & $<0.01$ & $<0.01$ & $<0.1$ & $<0.1$ & $<0.1$ & $<0.01$ & $<0.01$ \\
\hline$S$ & 51577 & $<0.01$ & $<0.01$ & $<0.1$ & $<0.1$ & $<0.1$ & $<0.01$ & $<0.01$ \\
\hline & 51578 & $<0.01$ & $<0.01$ & $<0.1$ & $<0.1$ & $<0.1$ & $<0.01$ & $<0.01$ \\
\hline & 51581 & $<0.01$ & $<0.01$ & $<0.1$ & $<0.1$ & $<0.1$ & $<0.01$ & $<0.01$ \\
\hline$s$ & 51582 & $<0.01$ & $<0.01$ & $<0.1$ & $<0.1$ & $<0.1$ & $<0.01$ & 0.02 \\
\hline & 51587 & $<0.01$ & $<0.01$ & $<0.1$ & $<0.1$ & $<0.1$ & $<0.01$ & $<0.01$ \\
\hline$S$ & 51588 & $<0.01$ & $<0.01$ & $<0.1$ & $<0.1$ & $<0.1$ & $<0.01$ & $<0.01$ \\
\hline $\mathrm{s}$ & 51589 & $<0.01$ & $<0.01$ & $<0.1$ & $<0.1$ & $<0.1$ & $<0.01$ & $<0.01$ \\
\hline & 52383 & $<0.01$ & $<0.01$ & $<0.1$ & $<0.1$ & $<0.1$ & $<0.01$ & $<0.01$ \\
\hline \multicolumn{9}{|c|}{ UNDEVELOPED AREA } \\
\hline $\mathrm{s}$ & 34742 & $<0.01$ & $<0.01$ & $<0.1$ & $<0.1$ & $<0.1$ & $<0.01$ & $<0.01$ \\
\hline$S$ & 46544 & $<0.01$ & $<0.01$ & $<0.1$ & $<0.1$ & $<0.1$ & $<0.01$ & $<0.01$ \\
\hline $\mathrm{S}$ & 47755 & $<0.01$ & $<0.01$ & $<0.1$ & $<0.1$ & $<0.1$ & $<0.01$ & $<0.01$ \\
\hline$S$ & 48584 & $<0.01$ & $<0.01$ & $<0.1$ & $<0.1$ & $<0.1$ & $<0.01$ & $<0.01$ \\
\hline & 48946 & $<0.01$ & $<0.01$ & $<0.1$ & $<0.1$ & $<0.1$ & $<0.01$ & $<0.01$ \\
\hline $\mathrm{S}$ & 54886 & $<0.01$ & $<0.01$ & $<0.1$ & $<0.1$ & $<0.1$ & $<0.01$ & $<0.01$ \\
\hline & 73807 & $<0.01$ & $<0.01$ & $<0.1$ & $<0.1$ & $<0.1$ & $<0.01$ & $<0.01$ \\
\hline $\mathrm{S}$ & 73811 & $<0.01$ & $<0.01$ & $<0.1$ & $<0.1$ & $<0.1$ & $<0.01$ & $<0.01$ \\
\hline $\mathrm{S}$ & 74293 & $<0.01$ & $<0.01$ & $<0.1$ & $<0.1$ & $<0.1$ & $<0.01$ & $<0.01$ \\
\hline & 74294 & $<0.01$ & $<0.01$ & $<0.1$ & $<0.1$ & $<0.1$ & $<0.01$ & $<0.01$ \\
\hline & 74295 & $<0.01$ & $<0.01$ & $<0.1$ & $<0.1$ & $<0.1$ & $<0.01$ & $<0.01$ \\
\hline$S$ & 74301 & $<0.01$ & $<0.01$ & $<0.1$ & $<0.1$ & $<0.1$ & $<0.01$ & $<0.01$ \\
\hline$S$ & 74307 & $<0.01$ & $<0.01$ & $<0.1$ & $<0.1$ & $<0.1$ & $<0.01$ & $<0.01$ \\
\hline & 86583 & $<0.01$ & $<0.01$ & $<0.1$ & $<0.1$ & $<0.1$ & $<0.01$ & $<0.01$ \\
\hline & 86584 & $<0.01$ & $<0.01$ & $<0.1$ & $<0.1$ & $<0.1$ & $<0.01$ & $<0.01$ \\
\hline
\end{tabular}


Table 9B.--Chlorophenoxy-acid herbicides, triazine herbicides, organophosphorus insecticides, organochlorine insecticides, and carbamate insecticides not detected in water samples from network wells

[Detection limits are in micrograms per liter]

\begin{tabular}{ll}
\hline Constituent & Detection Limit \\
\hline
\end{tabular}

CHLOROPHENOXY ACID HERBICIDES

$2,4-\mathrm{DP}$

$2,4,5-\mathrm{T}$

TRIAZINE HERBICIDES
0.01

.01

.1
.1
.1
.1
.1
.1
.1
.1
.1

ORGANOPHOSPHORUS INSECTICIDES
Malathion

Methyl parathion

Methyl trithion

Parathion

Total trithion

.01

.01

.01

.01

.01

ORGANOCHLORINE INSECTICIDES

Aldrin

Endrin

Polychlorinated biphenyls (PCB)

Polychlorinated naphthalenes (PCN)

Heptachlor

Mirex

Toxaphene

.1

.1

.01

.01

1.0

\section{CARBAMATE INSECTICIDES}

Aldicarb

1.0

3-Hydroxycarbofuran

1.0

Carbary 1

1.0

Methomy 1

1.0 
Table 10.--Carbamate insecticide concentrations in water samples from network wells

[Values are in micrograms per liter (ug/L)

\begin{tabular}{|c|c|c|c|c|}
\hline Well number & Aldicarb sulfoxide & Aldicarb sulfone & Carbofuran & Oxyamyl \\
\hline & LONG-TERM SEWE & ED SUBURBAN AREA & & \\
\hline N 9057 & $<1.0$ & $<1.0$ & $<1.0$ & $<1.0$ \\
\hline N 9803 & $<1.0$ & $<1.0$ & $<1.0$ & $<1.0$ \\
\hline N 9914 & $<1.0$ & $<1.0$ & $<1.0$ & $<1.0$ \\
\hline N 9940 & $<1.0$ & $<1.0$ & $<1.0$ & $<1.0$ \\
\hline N 9941 & $<1.0$ & $<1.0$ & $<1.0$ & $<1.0$ \\
\hline N 9942 & $<1.0$ & $<1.0$ & $<1.0$ & $<1.0$ \\
\hline N 9943 & $<1.0$ & $<1.0$ & $<1.0$ & $<1.0$ \\
\hline N 9944 & $<1.0$ & $<1.0$ & $<1.0$ & $<1.0$ \\
\hline N 9945 & $<1.0$ & $<1.0$ & $<1.0$ & $<1.0$ \\
\hline N 9946 & $<1.0$ & $<1.0$ & $<1.0$ & $<1.0$ \\
\hline N 9947 & $<1.0$ & $<1.0$ & $<1.0$ & $<1.0$ \\
\hline N 9948 & $<1.0$ & $<1.0$ & $<1.0$ & $<1.0$ \\
\hline N 9949 & $<1.0$ & $<1.0$ & $<1.0$ & $<1.0$ \\
\hline N 9959 & $<1.0$ & $<1.0$ & $<1.0$ & $<1.0$ \\
\hline N 9962 & $<1.0$ & $<1.0$ & $<1.0$ & $<1.0$ \\
\hline N 9979 & $<1.0$ & $<1.0$ & $<1.0$ & $<1.0$ \\
\hline N 9982 & $<1.0$ & $<1.0$ & $<1.0$ & $<1.0$ \\
\hline N 9983 & $<1.0$ & $<1.0$ & $<1.0$ & $<1.0$ \\
\hline N 9984 & $<1.0$ & $<1.0$ & $<1.0$ & $<1.0$ \\
\hline \multirow[t]{2}{*}{ N 10035} & $<1.0$ & $<1.0$ & $<1.0$ & $<1.0$ \\
\hline & RECENTLY SEWE & ED SUBURBAN AREA & & \\
\hline N 1197 & $<1.0$ & $<1.0$ & $<1.0$ & $<1.0$ \\
\hline N 8888 & $<1.0$ & $<1.0$ & $<1.0$ & $<1.0$ \\
\hline N 8984 & $<1.0$ & $<1.0$ & $<1.0$ & $<1.0$ \\
\hline N 9078 & $<1.0$ & $<1.0$ & $<1.0$ & $<1.0$ \\
\hline N 9079 & $<1.0$ & $<1.0$ & $<1.0$ & $<1.0$ \\
\hline N 9222 & $<1.0$ & $<1.0$ & $<1.0$ & $<1.0$ \\
\hline N 9354 & $<1.0$ & $<1.0$ & $<1.0$ & $<1.0$ \\
\hline N 9451 & $<1.0$ & $<1.0$ & $<1.0$ & $<1.0$ \\
\hline N 9917 & $<1.0$ & $<1.0$ & $<1.0$ & $<1.0$ \\
\hline N 9918 & $<1.0$ & $<1.0$ & $<1.0$ & $<1.0$ \\
\hline N 9919 & $<1.0$ & $<1.0$ & $<1.0$ & $<1.0$ \\
\hline N 9920 & $<1.0$ & $<1.0$ & $<1.0$ & $<1.0$ \\
\hline N 9924 & $<1.0$ & $<1.0$ & $<1.0$ & $<1.0$ \\
\hline N 9925 & $<1.0$ & $<1.0$ & $<1.0$ & $<1.0$ \\
\hline N 9926 & $<1.0$ & $<1.0$ & $<1.0$ & $<1.0$ \\
\hline N 9927 & $<1.0$ & $<1.0$ & $<1.0$ & $<1.0$ \\
\hline N 9928 & $<1.0$ & $<1.0$ & $<1.0$ & $<1.0$ \\
\hline N 9933 & $<1.0$ & $<1.0$ & $<1.0$ & $<1.0$ \\
\hline N 9938 & $<1.0$ & $<1.0$ & $<1.0$ & $<1.0$ \\
\hline N 9939 & $<1.0$ & $<1.0$ & $<1.0$ & $<1.0$ \\
\hline
\end{tabular}


Table 10.--Carbamate insecticide concentrations in water samples from network wells (cont inued)

\begin{tabular}{|c|c|c|c|c|}
\hline Well number & Aldicarb sulfoxide & Aldicarb sulfone & Carbofuran & Oxyamyl \\
\hline \multicolumn{5}{|c|}{ UNSEWERED SUBURBAN AREA } \\
\hline S 24771 & $<1.0$ & $<1.0$ & $<1.0$ & $<1.0$ \\
\hline S 29778 & $<1.0$ & $<1.0$ & $<1.0$ & $<1.0$ \\
\hline S 45207 & $<1.0$ & $<1.0$ & $<1.0$ & $<1.0$ \\
\hline S 45208 & $<1.0$ & $<1.0$ & $<1.0$ & $<1.0$ \\
\hline S 45210 & $<1.0$ & $<1.0$ & $<1.0$ & $<1.0$ \\
\hline S 45594 & $<1.0$ & $<1.0$ & $<1.0$ & $<1.0$ \\
\hline S 46283 & $<1.0$ & $<1.0$ & $<1.0$ & $<1.0$ \\
\hline S 47220 & $<1.0$ & $<1.0$ & $<1.0$ & $<1.0$ \\
\hline S 48375 & $<1.0$ & $<1.0$ & 1.0 & $<1.0$ \\
\hline S 50513 & $<1.0$ & $<1.0$ & $<1.0$ & $<1.0$ \\
\hline S 64313 & $<1.0$ & $<1.0$ & $<1.0$ & $<1.0$ \\
\hline S 64314 & $<1.0$ & $<1.0$ & $<1.0$ & $<1.0$ \\
\hline S 64316 & $<1.0$ & $<1.0$ & $<1.0$ & $<1.0$ \\
\hline S 64318 & $<1.0$ & $<1.0$ & $<1.0$ & $<1.0$ \\
\hline S 64319 & $<1.0$ & $<1.0$ & $<1.0$ & $<1.0$ \\
\hline S 65602 & $<1.0$ & $<1.0$ & $<1.0$ & $<1.0$ \\
\hline S 65607 & $<1.0$ & $<1.0$ & $<1.0$ & $<1.0$ \\
\hline S 68762 & $<1.0$ & $<1.0$ & $<1.0$ & $<1.0$ \\
\hline S 74286 & $<1.0$ & $<1.0$ & $<1.0$ & $<1.0$ \\
\hline S 75456 & $<1.0$ & $<1.0$ & $<1.0$ & $<1.0$ \\
\hline \multicolumn{5}{|c|}{ AGRICULTURAL AREA } \\
\hline S 51566 & 22 & 20 & 7.0 & $<1.0$ \\
\hline S 51567 & 19 & 24 & 2.0 & $<1.0$ \\
\hline S 51568 & 26 & 32 & 7.0 & $<1.0$ \\
\hline S 51571 & 18 & 23 & 4.0 & $<1.0$ \\
\hline S 51572 & $<1.0$ & $<1.0$ & $<1.0$ & $<1.0$ \\
\hline S 51575 & $<1.0$ & $<1.0$ & $<1.0$ & $<1.0$ \\
\hline S 51576 & 6.0 & 6.0 & 5.0 & $<1.0$ \\
\hline S 51577 & 43 & 61 & 10 & $<1.0$ \\
\hline S 51578 & $<1.0$ & $<1.0$ & $<1.0$ & $<1.0$ \\
\hline S 51581 & 11 & 14 & 2.0 & $<1.0$ \\
\hline S 51582 & 13 & 12 & 7.0 & $<1.0$ \\
\hline S 51587 & 4.0 & 2.0 & $<1.0$ & 7.0 \\
\hline S 51588 & 6.0 & 10 & 3.0 & $<1.0$ \\
\hline S 51589 & $<1.0$ & $<1.0$ & $<1.0$ & $<1.0$ \\
\hline S 52383 & $<1.0$ & $<1.0$ & $<1.0$ & $<1.0$ \\
\hline \multicolumn{5}{|c|}{ UNDEVELOPED AREA } \\
\hline S 34742 & $<1.0$ & $<1.0$ & $<1.0$ & $<1.0$ \\
\hline S 46544 & $<1.0$ & $<1.0$ & $<1.0$ & $<1.0$ \\
\hline S 47755 & $<1.0$ & $<1.0$ & $<1.0$ & $<1.0$ \\
\hline S 48584 & $<1.0$ & $<1.0$ & $<1.0$ & $<1.0$ \\
\hline S 48946 & 1.0 & 2.0 & 1.0 & $<1.0$ \\
\hline S 54886 & $<1.0$ & $<1.0$ & $<1.0$ & $<1.0$ \\
\hline S 73807 & $<1.0$ & $<1.0$ & $<1.0$ & $<1.0$ \\
\hline S 73811 & $<1.0$ & $<1.0$ & $<1.0$ & $<1.0$ \\
\hline S 74293 & $<1.0$ & $<1.0$ & $<1.0$ & $<1.0$ \\
\hline S 74294 & $<1.0$ & $<1.0$ & $<1.0$ & $<1.0$ \\
\hline S 74295 & $<1.0$ & $<1.0$ & $<1.0$ & $<1.0$ \\
\hline S 74301 & $<1.0$ & $<1.0$ & $<1.0$ & $<1.0$ \\
\hline S 74307 & $<1.0$ & $<1.0$ & $<1.0$ & $<1.0$ \\
\hline S 86583 & $<1.0$ & $<1.0$ & $<1.0$ & $<1.0$ \\
\hline S 86584 & $<1.0$ & $<1.0$ & $<1.0$ & $<1.0$ \\
\hline
\end{tabular}


Table 11A.--Semivolatile organic compound concentrations in water samples from 24 resampled network wells

[Analyzed by the National Water Quality Laboratory; values are in micrograms per liter; <, less than; well locations shown in fig. 3]

\begin{tabular}{|c|c|c|c|c|}
\hline $\begin{array}{l}\text { Well } \\
\text { number }\end{array}$ & $\begin{array}{c}\text { Date } \\
\text { resampled }\end{array}$ & $\begin{array}{c}\text { Di-n- } \\
\text { octy1- } \\
\text { phthalate }\end{array}$ & $\begin{array}{c}\text { bis (2- } \\
\text { ethyl- } \\
\text { hexyl) } \\
\text { phthalate }\end{array}$ & $\begin{array}{l}\text { Naph- } \\
\text { thalene }\end{array}$ \\
\hline
\end{tabular}

LONG-TERM SEWERED SUBURBAN AREA

$\begin{array}{lllll}\text { N } 9914 & 03-31-88 & <10 & <5.0 & <5.0 \\ \text { N } 9940 & 05-10-88 & <10 & <5.0 & <5.0 \\ \text { N } 9941 & 06-02-88 & <10 & <5.0 & <5.0 \\ \text { N } 9942 & 04-06-88 & <10 & <5.0 & <5.0 \\ \text { N } 9943 & 06-03-88 & <10 & <5.0 & <5.0 \\ \text { N } 9944 & 06-08-88 & <10 & <5.0 & <5.0 \\ \text { N } 9945 & 04-07-88 & <10 & <5.0 & <5.0 \\ \text { N } 9946 & 03-31-88 & <10 & <5.0 & <5.0 \\ \text { N } 9948 & 06-07-88 & <10 & 5.0 & <5.0 \\ \text { N } 9949 & 06-06-88 & <10 & <5.0 & <5.0 \\ \text { N } 9982 & 04-06-88 & <10 & <5.0 & <5.0 \\ \text { N } 9983 & 06-09-88 & <10 & <5.0 & <5.0 \\ \text { N } 9984 & 07-26-88 & <10 & <5.0 & <5.0\end{array}$

RECENTLY SEWERED SUBURBAN AREA

$\begin{array}{ccccc}\text { N } 9919 & 07-26-88 & <10 & <21 & <5.0 \\ \text { N } 9079 & 11-28-88 & <10 & 6.0 & 35\end{array}$

UNSEWERED SUBURBAN AREA

$\begin{array}{rrrll}\text { S } 45594 & 04-07-88 & <10 & <5.0 & <5.0 \\ \text { S } 47220 & 06-13-88 & 15 & 27 & <5.0 \\ \text { S } 65602 & 06-14-88 & 23 & <5.0 & <5.0 \\ \text { S } 50513 & 06-10-88 & <10 & <5.0 & <5.0 \\ \text { S } 68762 & 06-15-88 & <10 & <5.0 & <5.0\end{array}$

AGRICULTURAL AREA

$\begin{array}{lllll}\text { S } 51571 & 05-09-88 & <10 & <5.0 & <5.0 \\ \text { S } 51575 & 05-10-88 & <10 & 12 & <5.0 \\ \text { S } 51581 & 05-09-88 & <10 & <5.0 & <5.0 \\ \text { S } 51589 & 04-19-88 & <10 & <5.0 & <5.0\end{array}$

UNDEVELOPED AREA

$\begin{array}{llll}S 74301 \quad 06-16-88 & <10 & <5.0 & <5.0\end{array}$


Table 11B.--Semivolatile organic compounds not detected in water samples from 24 resampled network wells

[Analyses by the National Water Quality Laboratory. All values are in micrograms per liter]

\begin{tabular}{|c|c|}
\hline Constituent & Detection Limit \\
\hline $1,2,4$-Trichlorobenzene & 5.0 \\
\hline $1,2,5,6$-Dibenzanthracene & 10.0 \\
\hline 1,2-Dichlorobenzene & 5.0 \\
\hline 1,3-Dichlorobenzene & 5.0 \\
\hline 1,4-Dichlorobenzene & 5.0 \\
\hline $2,4,6$-Trichlorophenol & 20.0 \\
\hline 2,4-Dichlorophenol & 5.0 \\
\hline 2,4-Dimethylphenol & 5.0 \\
\hline 2,4-Dinitrophenol & 20.0 \\
\hline 2,4-Dinitrotoluene & 5.0 \\
\hline 2,6-Dinitrotoluene & 5.0 \\
\hline 2-Chloronaphthalene & 5.0 \\
\hline 2-Chlorophenol & 5.0 \\
\hline 2-Methyl-4,6-dinitrophenol & 30.0 \\
\hline 2-Nitrophenol & 5.0 \\
\hline 4-Bromophenylphenylether & 5.0 \\
\hline 4-Chloro-3-methylphenol & 30.0 \\
\hline 4-Chloropheny lpheny let her & 5.0 \\
\hline 4-Nitrophenol & 30.0 \\
\hline Acenaphthene & 5.0 \\
\hline Acenapthylene & 5.0 \\
\hline Anthracene & 5.0 \\
\hline Benzo (a) anthracene & 5.0 \\
\hline Benzo (a) pyrene & 10.0 \\
\hline Benzo (b) fluoranthene & 10.0 \\
\hline Benzo(ghi)perylene & 10.0 \\
\hline Benzo (k) fluoranthene & 10.0 \\
\hline Chrysene & 10.0 \\
\hline Dimethylphthalate & 5.0 \\
\hline Di-n-butyl phthalate & 5.0 \\
\hline Diethylphthalate & 5.0 \\
\hline Fluoranthene & 5.0 \\
\hline Fluorene & 5.0 \\
\hline Hexachlorobenzene & 5.0 \\
\hline Hexachlorobutadiene & 5.0 \\
\hline Hexachlorocyclopentadiene & 5.0 \\
\hline Hexachloroethane & 5.0 \\
\hline Indeno $(1,2,3$-cd) pyrene & 10.0 \\
\hline Isophorone & 5.0 \\
\hline$N$-Nitrosodi-n-Propylamine & 5.0 \\
\hline $\mathrm{N}$-Nitrosodimethylamine & 5.0 \\
\hline$N$-Nitrosodiphenylamine & 5.0 \\
\hline Nitrobenzene & 5.0 \\
\hline Pentachlorophenol & 30.0 \\
\hline Phenanthrene & 5.0 \\
\hline Phenol (C6H-50H) & 5.0 \\
\hline Pyrene & 5.0 \\
\hline bis (2-Chloroethoxy) methane & 5.0 \\
\hline bis $(2$-Chloroethyl) ether & 5.0 \\
\hline bis (2-Chloroisopropy 1 ) ether & 5.0 \\
\hline n-Butylbenzylphthalate & 5.0 \\
\hline
\end{tabular}




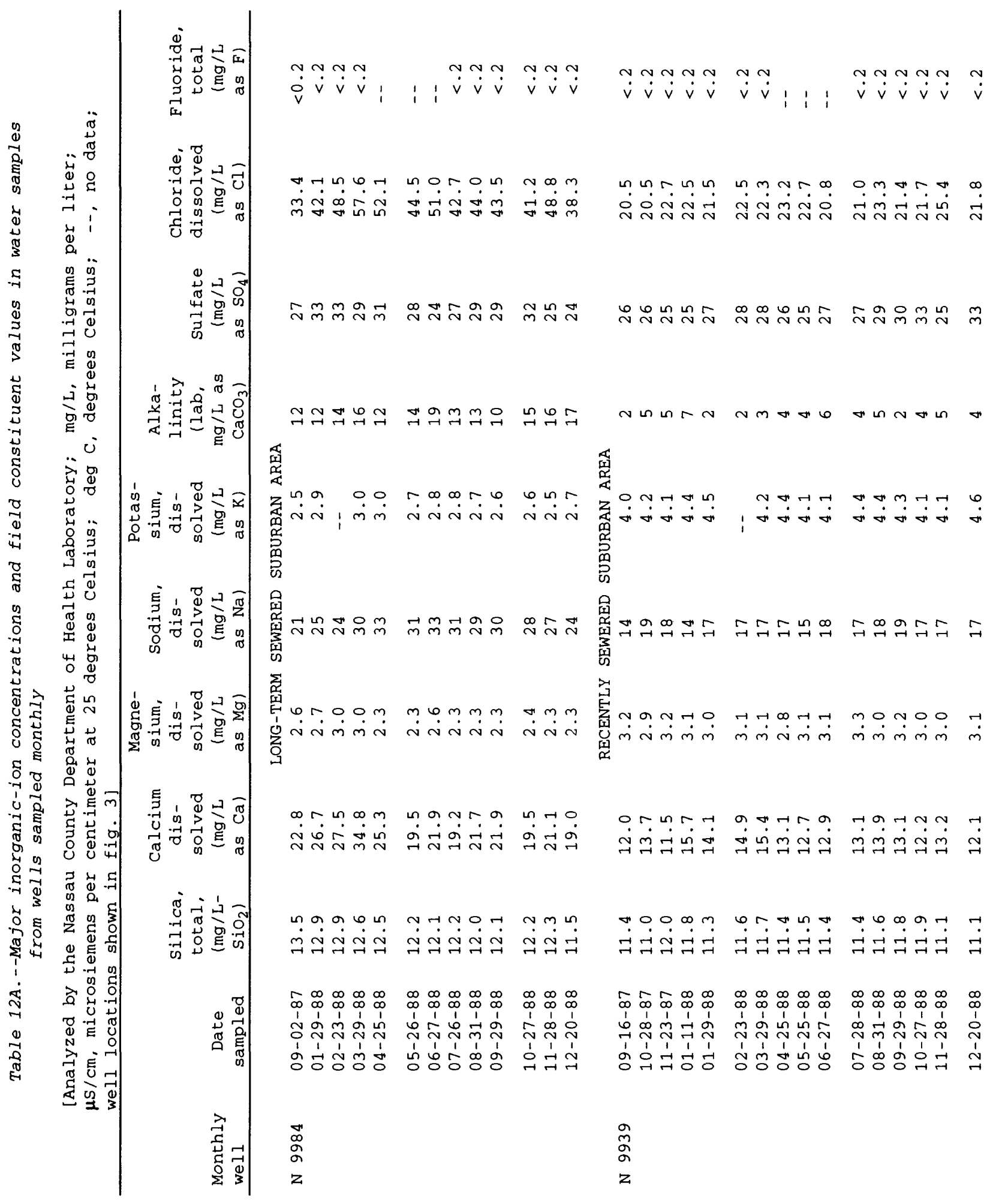




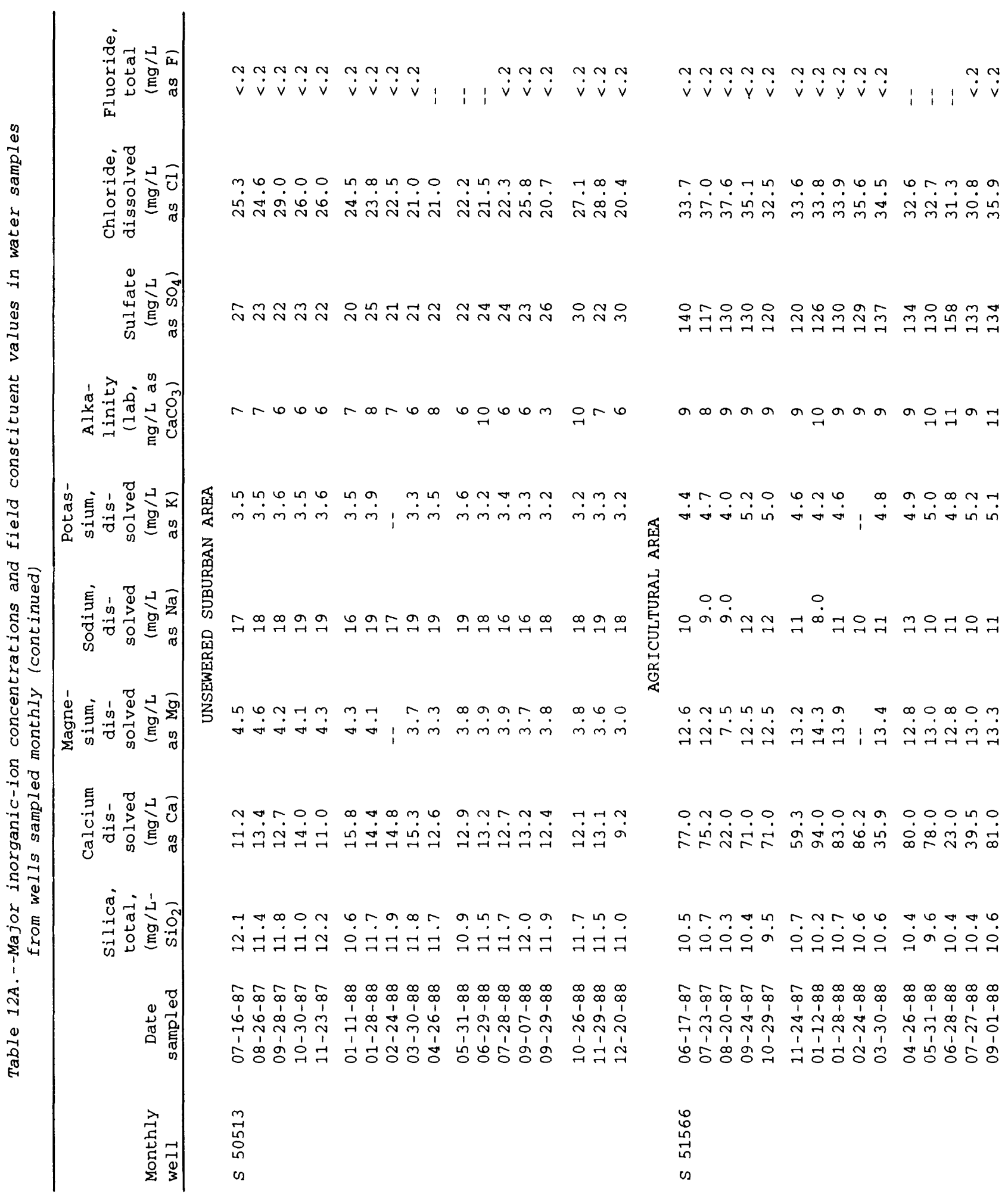




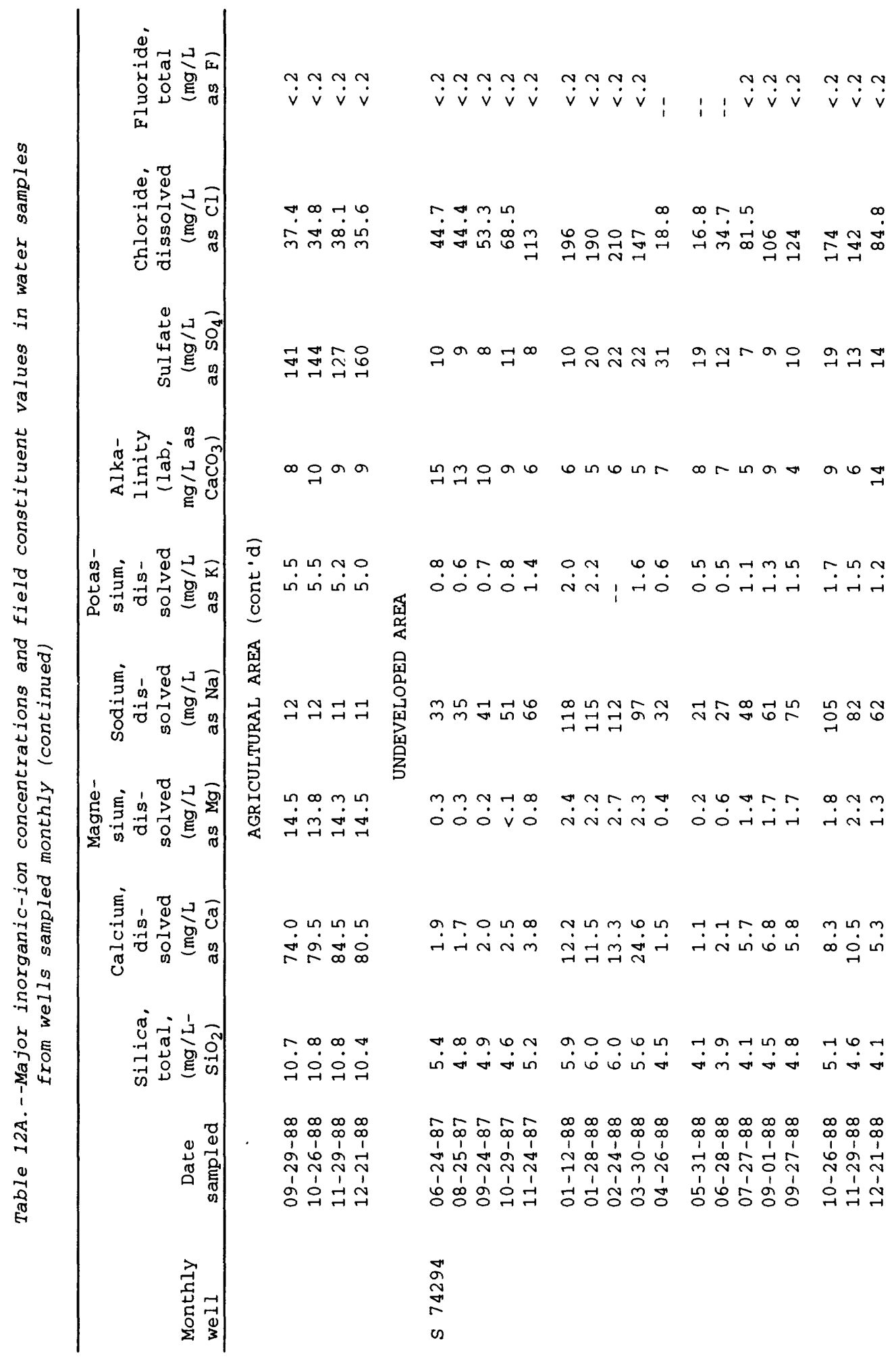




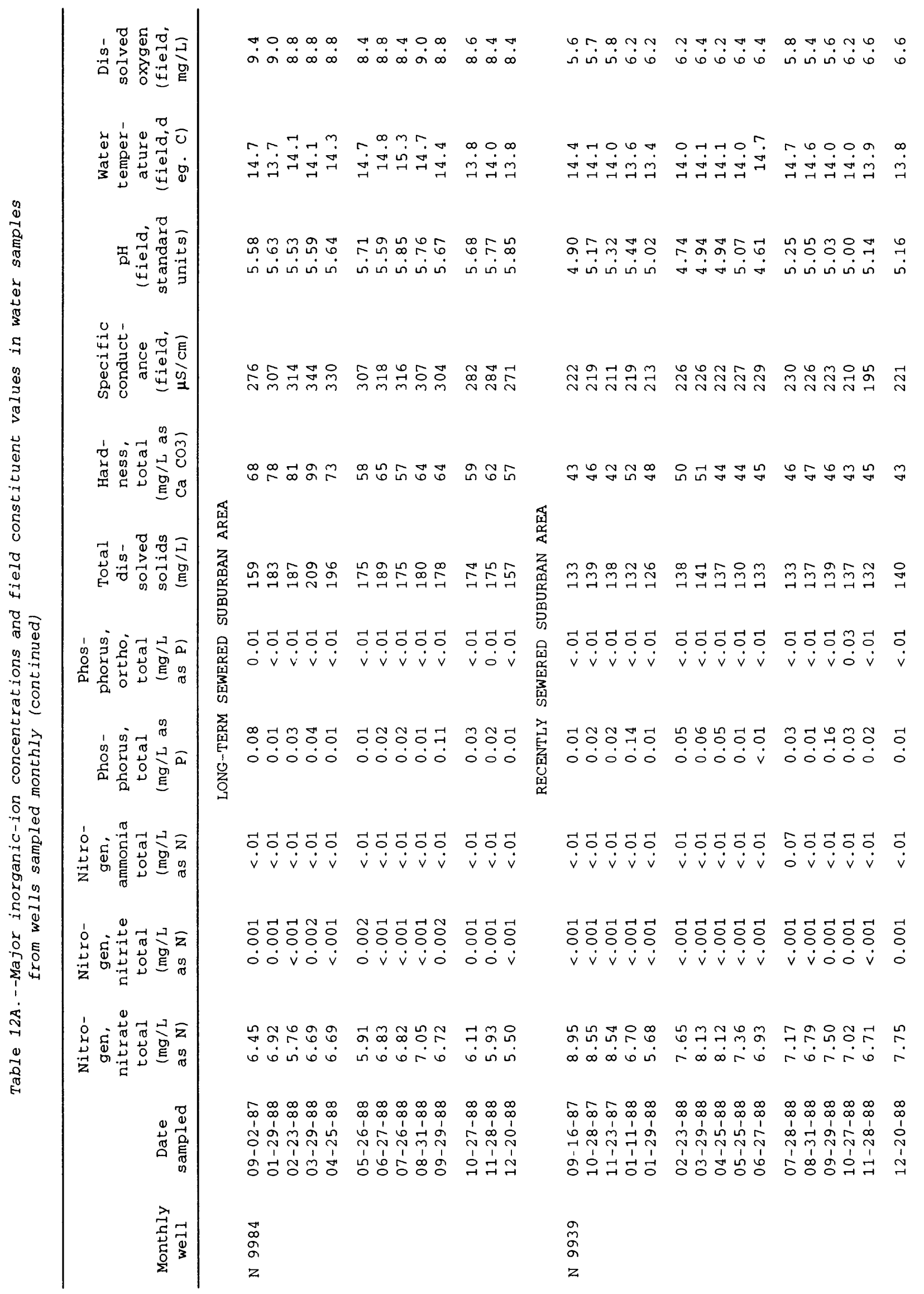




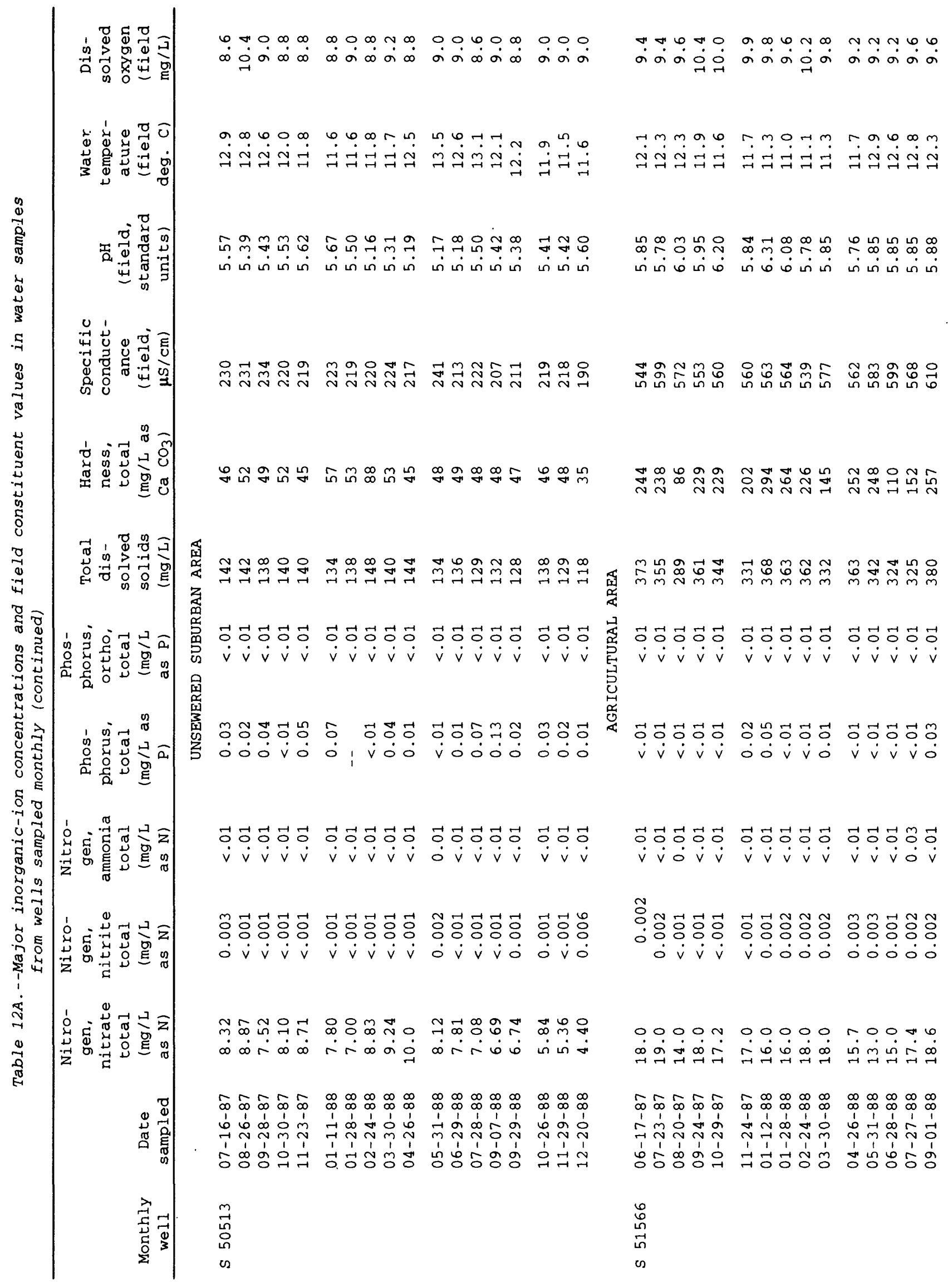




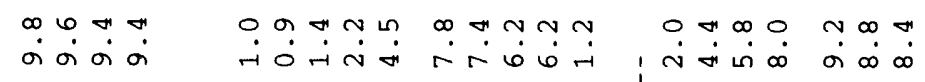

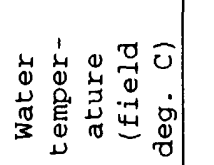

-

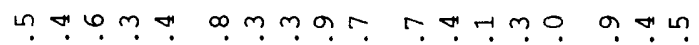

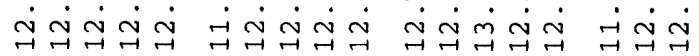

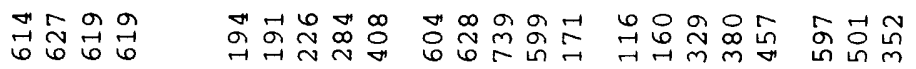

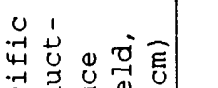

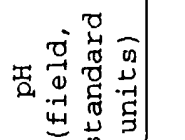

$\infty$ in 0 \% فن

ஸึ乚ั

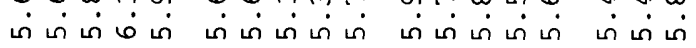

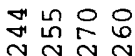

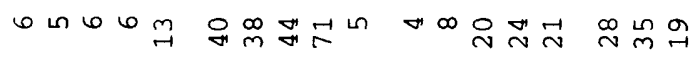

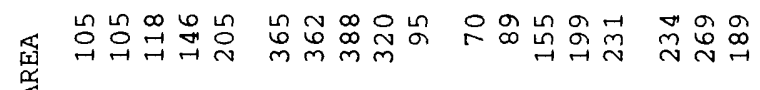

ํํ요용 $\dot{0} \dot{0} \dot{v} \dot{v}$

:̊ํ:융 ○ं0.ं

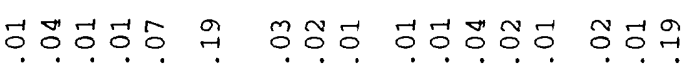
$\dot{v} \dot{0} \dot{v} \dot{v} \dot{0} \dot{0}, \dot{O} \dot{0} \dot{0} \dot{v} \dot{v} \dot{O} \dot{0} \dot{0} \dot{0} \dot{0} \dot{0}$

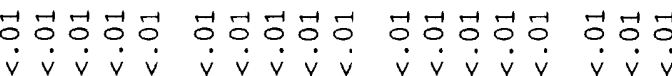

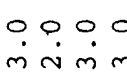

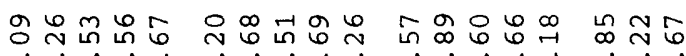

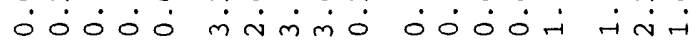

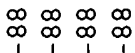

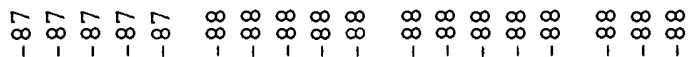

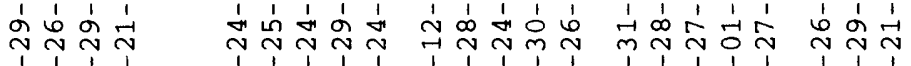

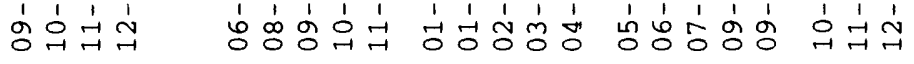

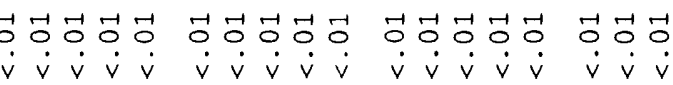

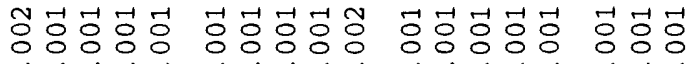
$\dot{o} \dot{v} \dot{v} \dot{v} \dot{v} \dot{v} \dot{v} \dot{v} \dot{v} \dot{o} \quad \dot{o} \dot{v} \dot{v} \dot{v} \dot{o} \dot{v} \dot{v} \dot{o}$ 
Table 12B.--Inorganic trace-element concentrations in water samples from wells sampled monthly ${ }^{1}$

[Values are in micrograms per liter $(\mathrm{ug} / \mathrm{L}) ;<$, less than, --, no data]

\begin{tabular}{|c|c|c|c|c|c|c|c|c|}
\hline \multicolumn{2}{|c|}{$\begin{array}{l}\text { Monthly } \\
\text { well }\end{array}$} & $\begin{array}{c}\text { Date } \\
\text { sampled }\end{array}$ & $\begin{array}{c}\text { Iron, } \\
\text { dissolved }\end{array}$ & $\begin{array}{r}\text { Manganese, } \\
\text { dissolved }\end{array}$ & $\begin{array}{c}\text { Barium, } \\
\text { dissolved }\end{array}$ & $\begin{array}{c}\text { Boron, } \\
\text { dissolved }\end{array}$ & $\begin{array}{c}\text { Cadmium, } \\
\text { dissolved }\end{array}$ & $\begin{array}{l}\text { Mercury, } \\
\text { dissolved }\end{array}$ \\
\hline \multicolumn{9}{|c|}{ LONG-TERM SEWERED SUBURBAN AREA } \\
\hline \multirow[t]{14}{*}{$\mathrm{N}$} & 9984 & $09-02-87$ & $<50$ & $<50$ & $<200$ & 60 & $<1$ & $<0.5$ \\
\hline & & $01-29-88$ & $<50$ & $<50$ & $<200$ & 30 & $<1$ & $<.5$ \\
\hline & & $02-23-88$ & $<50$ & $<50$ & $<200$ & 30 & $<1$ & $<.5$ \\
\hline & & $03-29-88$ & $<50$ & $<50$ & $<200$ & 40 & $<1$ & -- \\
\hline & & $04-25-88$ & $<50$ & $<50$ & $<200$ & 40 & $<1$ & -- \\
\hline & & $05-26-88$ & $<50$ & 100 & $<200$ & 40 & $<1$ & -- \\
\hline & & $06-27-88$ & 200 & 170 & $<200$ & 40 & $<1$ & -- \\
\hline & & $07-26-88$ & $<50$ & 130 & $<200$ & 40 & $<1$ & -. \\
\hline & & $08-31-88$ & $<50$ & 190 & $<200$ & 40 & $<1$ & -- \\
\hline & & $09-29-88$ & $<50$ & 200 & $<200$ & 40 & $<1$ & -- \\
\hline & & $10-27-88$ & $<50$ & 190 & $<200$ & 40 & $<1$ & -- \\
\hline & & $11-28-88$ & $<50$ & 160 & $<200$ & 40 & $<1$ & -- \\
\hline & & $12-20-88$ & 60 & 110 & $<200$ & 30 & $<1$ & -- \\
\hline & \multicolumn{8}{|c|}{ RECENTLY SEWERED SUBURBAN AREAS } \\
\hline \multirow[t]{16}{*}{$\mathrm{N}$} & 9939 & $09-16-87$ & $<50$ & 950 & $<200$ & $<10$ & $<1$ & $<.5$ \\
\hline & & $10-28-87$ & 50 & 960 & $<200$ & 70 & $<1$ & $<.5$ \\
\hline & & $11-23-87$ & 60 & 950 & $<200$ & 70 & $<1$ & $<.5$ \\
\hline & & $01-11-88$ & $<50$ & 1,030 & $<200$ & 70 & $<1$ & $<.5$ \\
\hline & & $01-29-88$ & $<50$ & 1,000 & $<200$ & 70 & $<1$ & $<.5$ \\
\hline & & $02-23-88$ & $<50$ & 990 & $<200$ & 60 & $<1$ & $<.5$ \\
\hline & & $03-29-88$ & $<50$ & 1,010 & $<200$ & 70 & $<1$ & -- \\
\hline & & $04-25-88$ & $<50$ & 970 & $<200$ & 70 & $<1$ & -- \\
\hline & & $05-25-88$ & $<50$ & 1.010 & $<200$ & 70 & $<1$ & -- \\
\hline & & $06-27-88$ & $<50$ & 990 & $<200$ & 70 & $<1$ & -- \\
\hline & & $07-28-88$ & $<50$ & 980 & $<200$ & 80 & $<1$ & -- \\
\hline & & $08-31-88$ & $<50$ & 930 & $<200$ & 70 & $<1$ & -- \\
\hline & & $09-29-88$ & $<50$ & 870 & $<200$ & 70 & 1 & -- \\
\hline & & $10-27-88$ & $<50$ & 880 & $<200$ & 80 & $<1$ & -- \\
\hline & & $11-28-88$ & $<50$ & 880 & $<200$ & 70 & $<1$ & -- \\
\hline & \multicolumn{8}{|c|}{ UNSEWERED SUBURBAN AREA } \\
\hline \multirow[t]{15}{*}{ S } & 50513 & $07-16-87$ & $<50$ & $<50$ & $<200$ & 70 & $<1$ & $<.5$ \\
\hline & & $08-26-87$ & $<50$ & $<50$ & $<200$ & 60 & $<1$ & $<.5$ \\
\hline & & $09-28-87$ & $<50$ & $<50$ & $<200$ & 80 & $<1$ & $<.5$ \\
\hline & & $10-30-87$ & $<50$ & 70 & $<200$ & 60 & $<1$ & $<.5$ \\
\hline & & $11-23-87$ & $<50$ & $<50$ & $<200$ & 60 & $<1$ & $<.5$ \\
\hline & & $01-11-88$ & $<50$ & 50 & $<200$ & 50 & $<1$ & $<.5$ \\
\hline & & $01-28-88$ & $<50$ & 60 & $<200$ & 50 & $<1$ & $<.5$ \\
\hline & & $02-24-88$ & $<50$ & 60 & $<200$ & 50 & $<1$ & $<.5$ \\
\hline & & $03-30-88$ & $<50$ & 50 & $<200$ & 60 & $<1$ & -- \\
\hline & & $04-26-88$ & $<50$ & $<50$ & $<200$ & 50 & $<1$ & - \\
\hline & & $05-31-88$ & 80 & 90 & $<200$ & 60 & $<1$ & -- \\
\hline & & $06-29-88$ & $<50$ & 60 & $<200$ & 50 & $<1$ & -- \\
\hline & & $07-28-88$ & $<50$ & 50 & $<200$ & 70 & $<1$ & -- \\
\hline & & $09-07-88$ & $<50$ & $<50$ & $<200$ & 40 & $<1$ & -- \\
\hline & & $09-29-88$ & $<50$ & $<50$ & $<200$ & 40 & 1 & -- \\
\hline \multirow{4}{*}{\multicolumn{2}{|c|}{, }} & $10-26-88$ & 50 & $<50$ & 200 & 50 & $<1$ & -- \\
\hline & & $11-29-88$ & $<50$ & $<50$ & $<200$ & 40 & $<1$ & -. \\
\hline & & $12-20-88$ & 70 & $<50$ & $<200$ & 40 & $<1$ & -- \\
\hline & & $12-20-88$ & 70 & $<50$ & $<200$ & 60 & $<1$ & - \\
\hline
\end{tabular}


Table 12B.--Inorganic trace-element concentrations in water samples from wells sampled monthly ${ }^{1}$ (contirued)

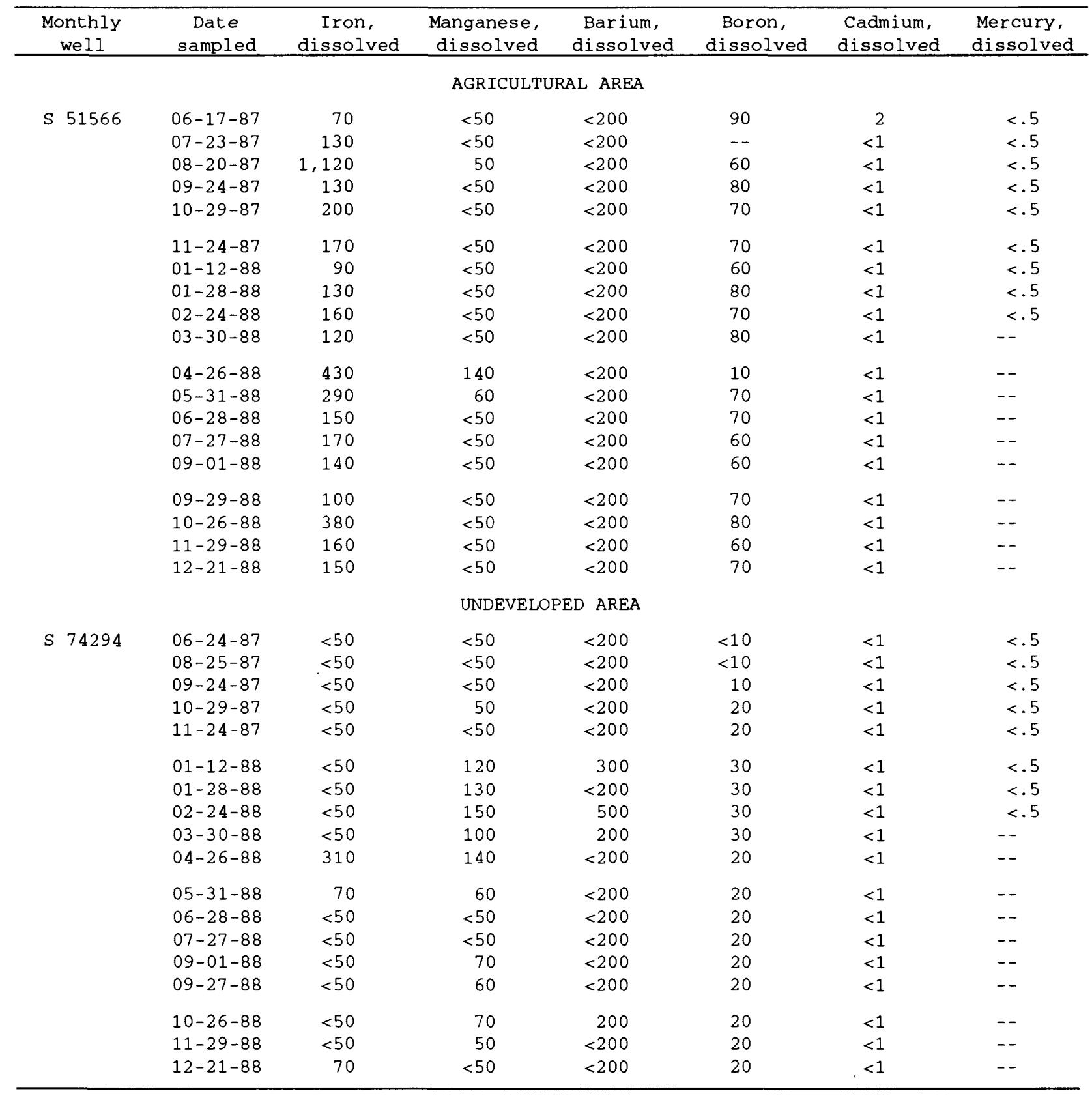

1. The following constituents had no detections above detection limit for the monthly wells (detection limit in parentheses); Arsenic $(5 \mu \mathrm{g} / \mathrm{L})$, Chromium (10 ug/L), Copper (50 $\mu \mathrm{g} / \mathrm{L})$, Lead $(10 \mu \mathrm{g} / \mathrm{L})$, Selenium $(5 \mu \mathrm{g} / \mathrm{L})$, Silver $(50 \mu \mathrm{g} / \mathrm{L})$, Methylene blue-active substances (0.02 milligrams per liter) 
Table 12C.--Volatile organic-compound concentrations in water samples from wells sampled monthly

[Analyzed by the Nassau County Department of Health Laboratory; values are in micrograms per liter $(\mu g / L) ;<$, less than --, no data]

\begin{tabular}{|c|c|c|c|c|c|c|c|c|c|}
\hline $\begin{array}{l}\text { Monthly } \\
\text { well }\end{array}$ & $\begin{array}{l}\text { Date } \\
\text { sampled }\end{array}$ & $\begin{array}{l}\text { Tri- } \\
\text { chloro- } \\
\text { fluoro- } \\
\text { methane }\end{array}$ & $\begin{array}{l}\text { trans- } \\
1,2-\mathrm{Di}- \\
\text { chloro- } \\
\text { ethylene }\end{array}$ & $\begin{array}{l}\text { 1,1-Di- } \\
\text { chloro- } \\
\text { ethane }\end{array}$ & $\begin{array}{c}\text { Chloro- } \\
\text { form }\end{array}$ & $\begin{array}{c}1,1,1- \\
\text { Tri- } \\
\text { chloro- } \\
\text { ethane }\end{array}$ & $\begin{array}{c}\text { Carbon- } \\
\text { tetra- } \\
\text { chlo- } \\
\text { ride }\end{array}$ & $\begin{array}{c}\text { Tri- } \\
\text { chloro- } \\
\text { ethylene }\end{array}$ & $\begin{array}{l}\text { Brom } \\
\text { di- } \\
\text { chlor } \\
\text { metho }\end{array}$ \\
\hline \multirow{14}{*}{ N 9984} & & & LONG-TE & RM SEWERE & SUBURBAN & AREA & & & \\
\hline & $09-02-87$ & $<1$ & $<7$ & $<5$ & $<1$ & 2 & $<1$ & $<1$ & $<2$ \\
\hline & $01-29-88$ & - & $<7$ & $<6$ & $<1$ & 1 & $<1$ & $<1$ & $<1$ \\
\hline & $02-23-88$ & - - & $<7$ & $<6$ & $<1$ & 1 & $<1$ & $<1$ & $<1$ \\
\hline & $03-29-88$ & -- & $<9$ & $<5$ & $<1$ & 2 & $<1$ & $<1$ & $<1$ \\
\hline & $04-25-88$ & $<1$ & $<8$ & $<4$ & $<1$ & 2 & $<1$ & $<1$ & $<1$ \\
\hline & $05-26-88$ & $<1$ & $<8$ & $<5$ & $<1$ & 1 & $<1$ & $<1$ & $<1$ \\
\hline & $06-27-88$ & $<1$ & $<8$ & $<4$ & $<1$ & 1 & $<1$ & $<1$ & $<1$ \\
\hline & $07-26-88$ & $<1$ & $<10$ & $<5$ & $<1$ & 1 & $<1$ & $<1$ & $<1$ \\
\hline & $08-31-88$ & $<1$ & $<11$ & $<2$ & $<1$ & $<1$ & $<1$ & $<1$ & $<2$ \\
\hline & $09-29-88$ & $<1$ & $<6$ & $<2$ & $<1$ & 1 & $<1$ & $<1$ & $<1$ \\
\hline & $10-27-88$ & $<1$ & $<6$ & $<2$ & $<1$ & 1 & $<1$ & $<1$ & $<1$ \\
\hline & $11-28-88$ & $<1$ & $<1$ & $<1$ & $<1$ & $<1$ & $<1$ & $<1$ & $<1$ \\
\hline & $12-20-88$ & $<1$ & $<1$ & $<1$ & $<1$ & $<1$ & $<1$ & $<1$ & $<1$ \\
\hline
\end{tabular}

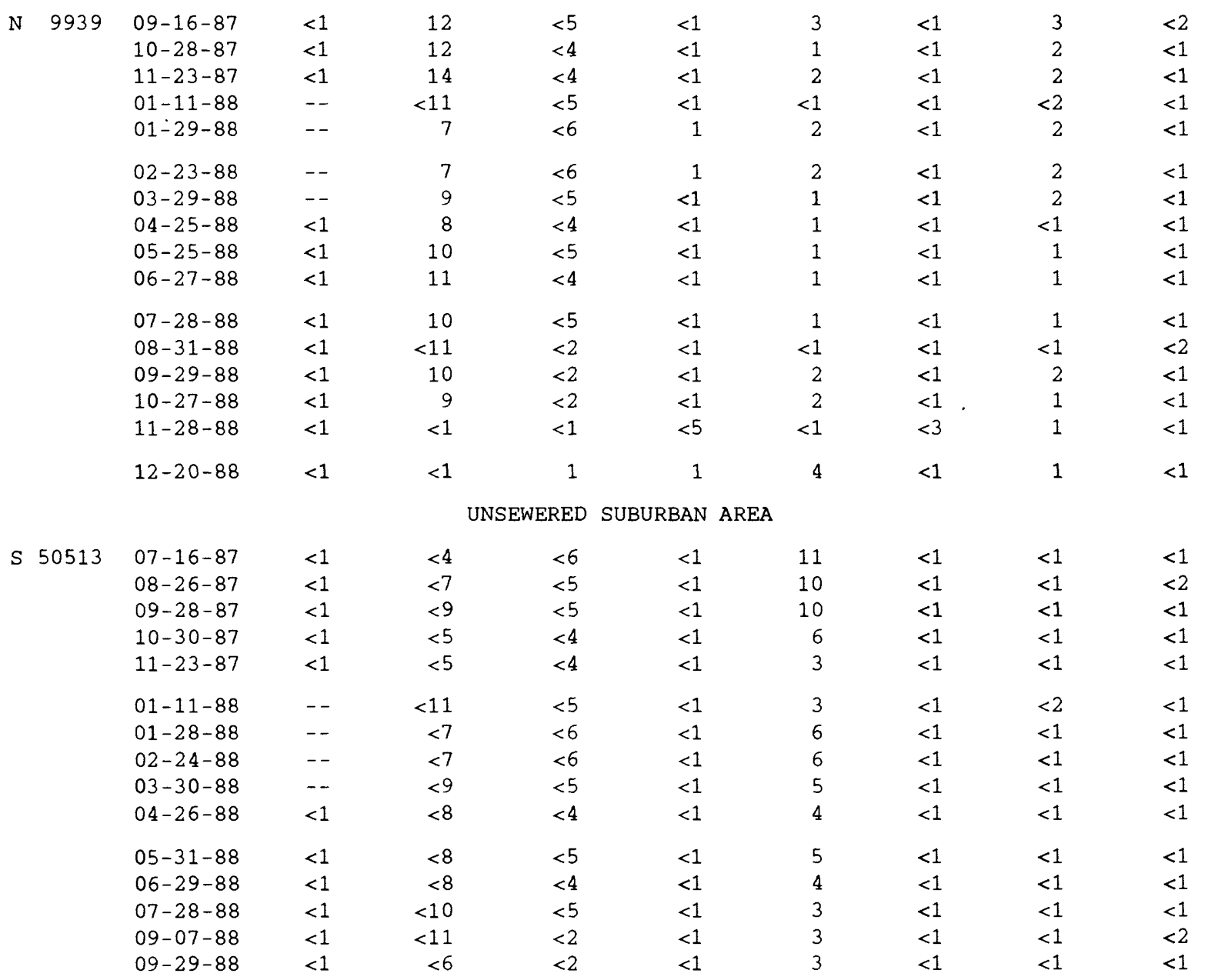


Table 12C.--Volatile organic compound concentrations in water samples from wells sampled monthly (continued)

\begin{tabular}{|c|c|c|c|c|c|c|c|c|c|}
\hline $\begin{array}{l}\text { Monthly } \\
\text { well }\end{array}$ & $\begin{array}{l}\text { Date } \\
\text { sampled }\end{array}$ & $\begin{array}{l}\text { Tri- } \\
\text { chloro- } \\
\text { fluoro- } \\
\text { methane }\end{array}$ & $\begin{array}{c}\text { trans- } \\
1,2-D i- \\
\text { chloro- } \\
\text { ethylene }\end{array}$ & $\begin{array}{c}1,1-\mathrm{Di}- \\
\text { chloro- } \\
\text { ethane }\end{array}$ & $\begin{array}{c}\begin{array}{c}\text { Chloro- } \\
\text { form }\end{array} \\
\end{array}$ & $\begin{array}{c}1,1,1- \\
\text { Tri- } \\
\text { chloro- } \\
\text { ethane }\end{array}$ & $\begin{array}{l}\text { Carbon- } \\
\text { tetra- } \\
\text { chlo- } \\
\text { ride }\end{array}$ & $\begin{array}{c}\text { Tri- } \\
\text { chloro- } \\
\text { ethylene }\end{array}$ & $\begin{array}{l}\text { Bromo- } \\
\text { di- } \\
\text { chloro- } \\
\text { methane }\end{array}$ \\
\hline & & & UNSEWERED & SUBURBAN & AREA $(\mathrm{CO}$ & (TINUED) & & & \\
\hline & $10-26-88$ & $<1$ & $<6$ & $<2$ & 1 & 2 & $<1$ & $<1$ & $<1$ \\
\hline & $11-29-88$ & $<1$ & $<1$ & $<1$ & $<1$ & 2 & $<1$ & $<1$ & $<1$ \\
\hline & $12-20-88$ & $<1$ & $<1$ & $<1$ & $<1$ & 2 & $<1$ & $<1$ & $<1$ \\
\hline & & & & AGRICULTU & RAL AREA & & & & \\
\hline \multirow{19}{*}{ S 51566} & $06-17-87$ & $<1$ & $<9$ & $<5$ & $<1$ & $<1$ & $<1$ & $<1$ & $<1$ \\
\hline & $07-23-87$ & $<1$ & $<4$ & $<6$ & $<1$ & $<1$ & $<1$ & $<1$ & $<1$ \\
\hline & $08-20-87$ & $<1$ & $<3$ & $<4$ & $<1$ & $<1$ & $<1$ & $<1$ & $<1$ \\
\hline & $09-24-87$ & $<1$ & $<7$ & $<5$ & $<1$ & $<1$ & $<1$ & $<1$ & $<2$ \\
\hline & $10-29-87$ & $<1$ & $<5$ & $<4$ & $<1$ & $<1$ & $<1$ & $<1$ & $<1$ \\
\hline & $11-24-87$ & $<1$ & $<5$ & $<4$ & $<1$ & $<1$ & $<1$ & $<1$ & $<1$ \\
\hline & $01-12-88$ & -- & $<11$ & $<5$ & $<1$ & $<1$ & $<1$ & $<2$ & $<1$ \\
\hline & $01-28-88$ & -- & $<7$ & $<6$ & $<1$ & $<1$ & $<1$ & $<1$ & $<1$ \\
\hline & $02-24-88$ & -- & $<7$ & $<6$ & $<1$ & $<1$ & $<1$ & $<1$ & $<1$ \\
\hline & $03-30-88$ & -- & $<9$ & $<5$ & $<1$ & $<1$ & $<1$ & $<1$ & $<1$ \\
\hline & $04-26-88$ & $<1$ & $<8$ & $<4$ & $<1$ & $<1$ & $<1$ & $<1$ & $<1$ \\
\hline & $05-31-88$ & $<1$ & $<8$ & $<5$ & $<1$ & $<1$ & $<1$ & $<1$ & $<1$ \\
\hline & $06-28-88$ & $<1$ & $<8$ & $<4$ & $<1$ & $<1$ & $<1$ & $<1$ & $<1$ \\
\hline & $07-27-88$ & $<1$ & $<10$ & $<5$ & $<1$ & $<1$ & $<1$ & $<1$ & $<1$ \\
\hline & $09-01-88$ & $<1$ & $<11$ & $<2$ & $<1$ & $<1$ & $<1$ & $<1$ & $<2$ \\
\hline & $09-29-88$ & $<1$ & $<6$ & $<2$ & $<1$ & $<1$ & $<1$ & $<1$ & $<1$ \\
\hline & $10-26-88$ & $<1$ & $<6$ & $<2$ & $<1$ & $<1$ & $<1$ & $<1$ & $<1$ \\
\hline & $11-29-88$ & $<1$ & $<1$ & $<1$ & $<1$ & $<1$ & $<1$ & $<1$ & $<1$ \\
\hline & $12-21-88$ & $<1$ & $<1$ & $<1$ & $<1$ & $<1$ & $<1$ & $<1$ & $<1$ \\
\hline
\end{tabular}

S 74294

$06-24-87$

$08-25-87$

$09-24-87$

$10-29-87$

$11-24-87$

$01-12-88$

$01-28-88$

$02-24-88$

$03-30-88$

$04-26-88$

$05-31-88$

$06-28-88$

$07-27-88$

$09-01-88$

$09-27-88$

$10-26-88$

$11-29-88$

$12-21-88$

$\begin{array}{ll}<1 & <9 \\ <1 & <7 \\ <1 & <7 \\ <1 & <5 \\ <1 & <5 \\ -- & <11 \\ -- & <7 \\ -- & <7 \\ -- & <9 \\ <1 & <8 \\ <1 & <8 \\ <1 & <8 \\ <1 & <10 \\ <1 & <11 \\ <1 & <6 \\ <1 & <6 \\ <1 & <1 \\ <1 & <1 \\ <1 & <6\end{array}$

\section{UNDEVELOPED AREA}

$\begin{array}{llllll}<5 & <1 & <1 & <1 & <1 & <1 \\ <5 & <1 & <1 & <1 & <1 & <2 \\ <5 & <1 & <1 & <1 & <1 & <2 \\ <4 & <1 & <1 & <1 & <1 & <1 \\ <4 & <1 & <1 & <1 & <1 & <1 \\ <5 & <1 & <1 & <1 & <2 & <1 \\ <6 & <1 & <1 & <1 & <1 & <1 \\ <6 & <1 & <1 & <1 & <1 & <1 \\ <5 & <1 & <1 & <1 & <1 & <1 \\ <4 & <1 & <1 & <1 & <1 & <1 \\ <5 & <1 & <1 & <1 & <1 & <1 \\ <4 & <1 & <1 & <1 & <1 & <1 \\ <5 & <1 & <1 & <1 & <1 & <1 \\ <2 & <1 & <1 & <1 & <1 & <2 \\ <2 & <1 & <1 & <1 & <1 & <1 \\ <2 & <1 & <1 & <1 & <1 & <1 \\ <1 & <1 & <1 & <1 & <1 & <1 \\ <1 & <1 & <1 & <1 & <1 & <1\end{array}$


Table 12C.--Volatile organic-compound concentrations in water samples from wells sampled monthly (continued)

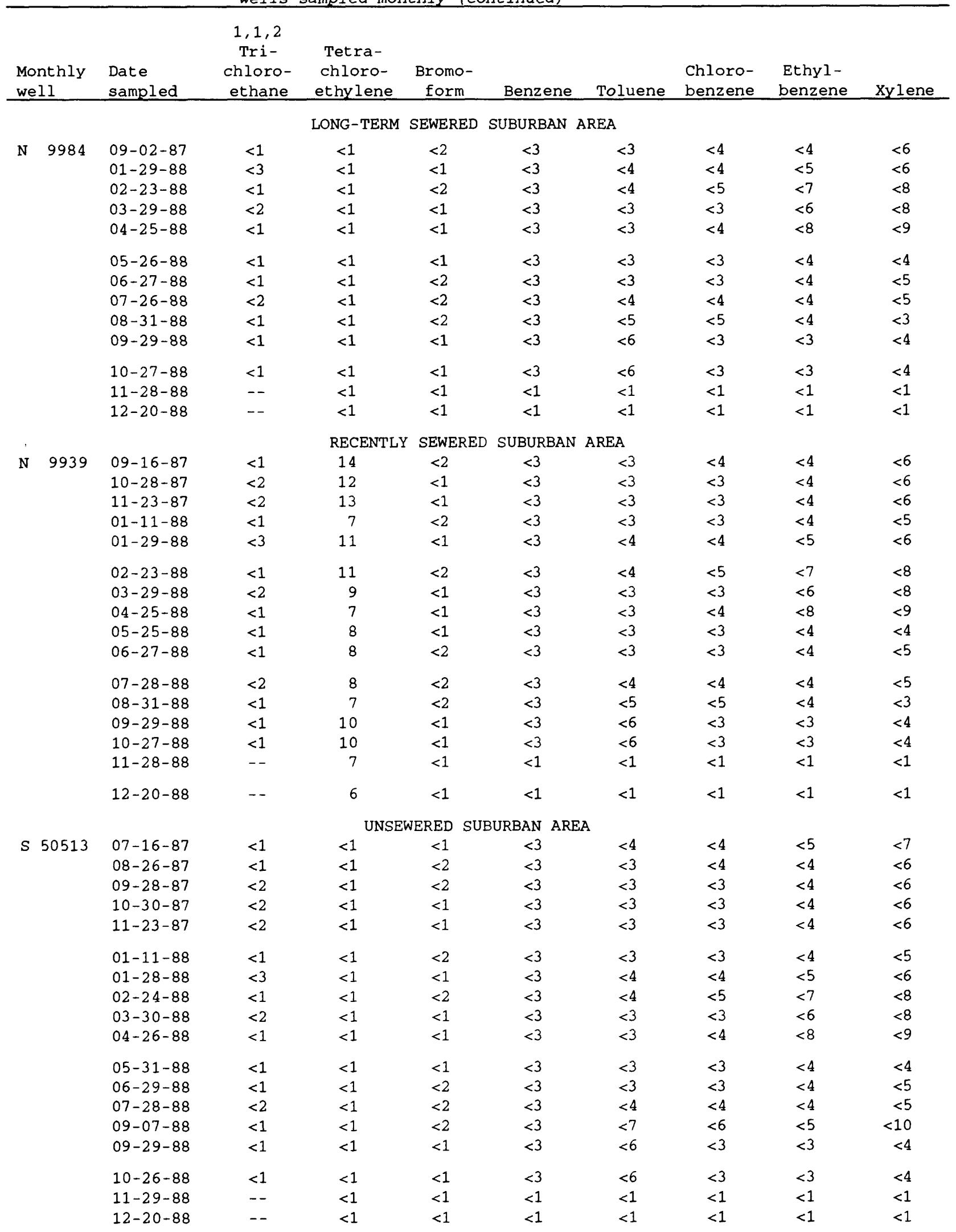


Table 12C.--Volatile organic-compound concentrations in water samples from wells sampled monthly (continued)

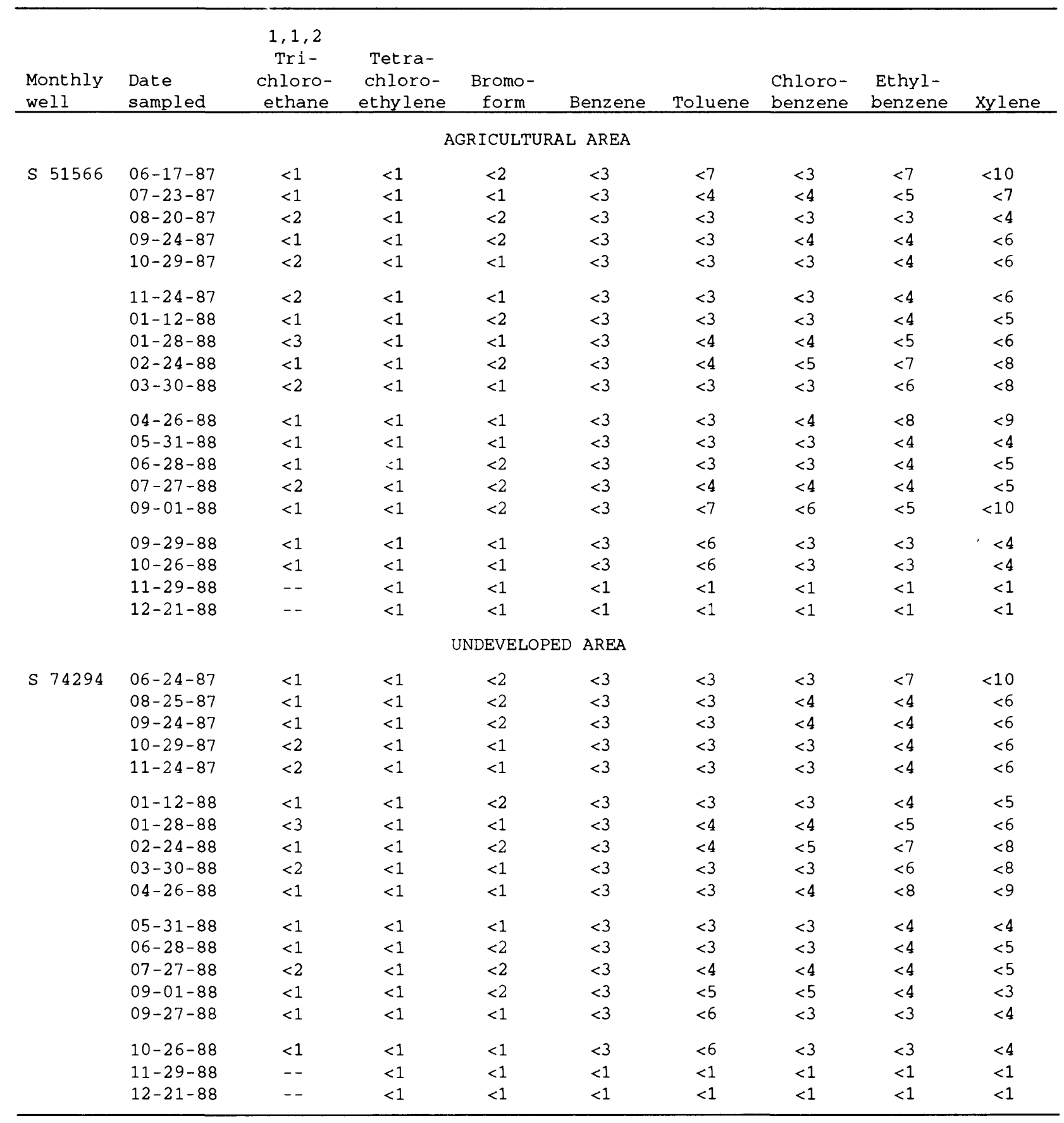


Table 12D.--Volatile organic-compound concentrations in six duplicate water samples from four wells sampled monthly

[Analyzed by the National water Quality Laboratory; values are in micrograms per liter $\left(\mu_{\mathrm{g} / \mathrm{L})}\right.$; <, less than; well locations shown in fig. 3]

\begin{tabular}{|c|c|c|c|c|c|c|c|c|c|c|}
\hline $\begin{array}{c}\text { Well } \\
\text { number }\end{array}$ & $\begin{array}{c}\text { Date } \\
\text { sampled } \\
\end{array}$ & Benzene & $\begin{array}{c}\text { Bromo- } \\
\text { form }\end{array}$ & $\begin{array}{l}\text { Carbon- } \\
\text { tetra- } \\
\text { chlo- } \\
\text { ride } \\
\end{array}$ & $\begin{array}{l}\text { Chloro- } \\
\text { benzene }\end{array}$ & $\begin{array}{l}\text { Chloro- } \\
\text { ethane }\end{array}$ & $\begin{array}{c}2- \\
\text { Chloro- } \\
\text { ethyl } \\
\text { vinyl } \\
\text { ether }\end{array}$ & $\begin{array}{c}\text { Chloro- } \\
\text { form }\end{array}$ & $\begin{array}{c}\text { Methyl- } \\
\text { chlor- } \\
\text { ide }\end{array}$ & $\begin{array}{l}\text { Chloro- } \\
\text { di- } \\
\text { bromo- } \\
\text { methane }\end{array}$ \\
\hline N 9984 & $11-28-88$ & $<0.2$ & $<0.2$ & $<0.2$ & $<0.2$ & $<0.2$ & $<0.2$ & 0.2 & $<0.2$ & $<0.2$ \\
\hline \multirow[t]{2}{*}{ N 9939} & $10-27-88$ & $<.2$ & $<.2$ & $<.2$ & $<.2$ & $<.2$ & $<.2$ & .7 & $<.2$ & $<.2$ \\
\hline & $11-28-88$ & $<.2$ & $<.2$ & $<.2$ & $<.2$ & $<.2$ & $<.2$ & $<.2$ & $<.2$ & $<.2$ \\
\hline \multirow{2}{*}{ S 50513} & $08-26-87$ & $<.2$ & $<.2$ & 3.1 & $<.2$ & $<.2$ & $<.2$ & 6.1 & $<.2$ & $<.2$ \\
\hline & $11-29-88$ & $<.2$ & $<.2$ & $<.2$ & $<.2$ & $<.2$ & $<.2$ & .9 & $<.2$ & $<.2$ \\
\hline S 74294 & $08-25-87$ & $<.2$ & $<.2$ & $<.2$ & $<.2$ & $<.2$ & $<.2$ & $<.2$ & $<.2$ & $<.2$ \\
\hline $\begin{array}{c}\text { Well } \\
\text { number }\end{array}$ & $\begin{array}{c}\text { Date } \\
\text { sampled }\end{array}$ & $\begin{array}{l}\text { Bromo- } \\
\text { di- } \\
\text { chloro- } \\
\text { methane }\end{array}$ & $\begin{array}{l}1,2 \text {-Di- } \\
\text { chloro- } \\
\text { benzene }\end{array}$ & $\begin{array}{l}1,3-\mathrm{Di}- \\
\text { chloro- } \\
\text { benzene }\end{array}$ & $\begin{array}{l}1,4-\mathrm{Di}- \\
\text { chloro- } \\
\text { benzene }\end{array}$ & $\begin{array}{c}\text { Di- } \\
\text { chloro- } \\
\text { di- } \\
\text { fluoro- } \\
\text { methane }\end{array}$ & $\begin{array}{l}1,1-\mathrm{Di}- \\
\text { chloro- } \\
\text { ethane }\end{array}$ & $\begin{array}{l}1,2-\mathrm{Di}- \\
\text { chloro- } \\
\text { ethane }\end{array}$ & $\begin{array}{l}\text { 1,1-Di- } \\
\text { chloro- } \\
\text { ethylene }\end{array}$ & \\
\hline N 9984 & $11-28-88$ & $<.2$ & $<.2$ & $<.2$ & $<.2$ & $<.2$ & $<.2$ & $<.2$ & $<.2$ & \\
\hline \multirow{2}{*}{$\mathrm{N} 9939$} & $10-27-88$ & $<.2$ & $<.2$ & $<.2$ & $<.2$ & $<.2$ & 1.2 & $<.2$ & .2 & \\
\hline & $11-28-88$ & $<.2$ & $<.2$ & $<.2$ & $<.2$ & $<.2$ & 1.0 & $<.2$ & .3 & \\
\hline \multirow[t]{2}{*}{ S 50513} & $08-26-87$ & $<.2$ & $<.2$ & $<.2$ & $<.2$ & $<.2$ & 6.7 & $<.2$ & 1.3 & \\
\hline & $11-29-88$ & $<.2$ & $<.2$ & $<.2$ & $<.2$ & $<.2$ & .6 & $<.2$ & .2 & \\
\hline S 74294 & $08-25-87$ & $<.2$ & $<.2$ & $<.2$ & $<.2$ & $<.2$ & $<.2$ & $<.2$ & $<.2$ & \\
\hline $\begin{array}{c}\text { Well } \\
\text { number }\end{array}$ & $\begin{array}{c}\text { Date } \\
\text { sampled }\end{array}$ & $\begin{array}{l}\text { trans- } \\
1,2-D i- \\
\text { chloro- } \\
\text { ethylene }\end{array}$ & $\begin{array}{l}1,2-\mathrm{Di}- \\
\text { chloro- } \\
\text { propane }\end{array}$ & $\begin{array}{l}\text { cis- } \\
\text { 1,3-Di- } \\
\text { chloro- } \\
\text { propene }\end{array}$ & $\begin{array}{l}\text { 1,3-Di- } \\
\text { chloro- } \\
\text { propene }\end{array}$ & $\begin{array}{l}\text { Ethyl- } \\
\text { benzene }\end{array}$ & $\begin{array}{l}\text { Methyl } \\
\text { bromide }\end{array}$ & \multicolumn{3}{|c|}{$\begin{array}{c}\text { Methy- } \\
\text { lene } \\
\text { chlo- } \\
\text { ride } \\
\end{array}$} \\
\hline & $11-28-88$ & $<.2$ & $<.2$ & $<.2$ & $<.2$ & $<.2$ & $<.2$ & $<.2$ & $<.2$ & \\
\hline \multirow[t]{2}{*}{ N 9939} & $10-27-88$ & 11 & $<.2$ & $<.2$ & $<.2$ & $<.2$ & $<.2$ & $<.2$ & $<.2$ & \\
\hline & $11-28-88$ & 4.3 & $<.2$ & $<.2$ & $<.2$ & $<.2$ & $<.2$ & $<.2$ & $<.2$ & \\
\hline \multirow[t]{2}{*}{ S 50513} & $08-26-87$ & $<.2$ & $<.2$ & $<.2$ & $<.2$ & $<.2$ & $<.2$ & $<.2$ & $<.2$ & \\
\hline & $11-29-88$ & $<.2$ & $<.2$ & $<.2$ & $<.2$ & $<.2$ & $<.2$ & $<.2$ & $<.2$ & \\
\hline S 74294 & $08-25-87$ & $<.2$ & $<.2$ & $<.2$ & $<.2$ & $<.2$ & $<.2$ & $<.2$ & $<.2$ & \\
\hline $\begin{array}{c}\text { Well } \\
\text { number }\end{array}$ & $\begin{array}{c}\text { Date } \\
\text { sampled }\end{array}$ & $\begin{array}{c}1,1,2,2- \\
\text { Tetra- } \\
\text { chloro- } \\
\text { ethane } \\
\end{array}$ & $\begin{array}{l}\text { Tetra- } \\
\text { chloro- } \\
\text { ethylene }\end{array}$ & Toluene & $\begin{array}{c}\text { 1,1,1- } \\
\text { Tri- } \\
\text { chloro- } \\
\text { ethane }\end{array}$ & $\begin{array}{c}1,1,2- \\
\text { Tri- } \\
\text { chloro- } \\
\text { ethane } \\
\end{array}$ & $\begin{array}{c}\text { Tri- } \\
\text { chloro- } \\
\text { ethylene }\end{array}$ & $\begin{array}{l}\text { vinyl } \\
\text { chlo- } \\
\text { ride }\end{array}$ & Xylene & \\
\hline N 9984 & $11-28-88$ & $<.2$ & .4 & $<.2$ & .7 & $<.2$ & $<.2$ & $<.2$ & $<.2$ & \\
\hline \multirow[t]{2}{*}{ N 9939} & $10-27-88$ & $<.2$ & 7.6 & $<.2$ & 2.0 & $<.2$ & 1.4 & $<.2$ & $<.2$ & \\
\hline & $11-28-88$ & $<.2$ & 7.0 & .8 & 2.2 & $<.2$ & 1.2 & $<.2$ & $<.2$ & \\
\hline \multirow[t]{2}{*}{ S 50513} & $08-26-87$ & $<.2$ & 1.3 & $<.2$ & 16 & $<.2$ & $<.2$ & $<.2$ & $<.2$ & \\
\hline & $11-29-88$ & $<.2$ & .2 & $<.2$ & 1.9 & $<.2$ & $<.2$ & $<.2$ & $<.2$ & \\
\hline S 74294 & $08-25-87$ & $<.2$ & $<.2$ & $<.2$ & $<.2$ & $<.2$ & $<.2$ & $<.2$ & $<.2$ & \\
\hline
\end{tabular}


Table 13A.--Organochlorine-insecticide concentrations in water samples from well sampled monthly in agricultural area

[Values are in micrograms per liter (ug/L);

$<$, less than; --, no data]

\begin{tabular}{|c|c|c|c|c|}
\hline $\begin{array}{l}\text { Date } \\
\text { sampled }\end{array}$ & $\mathrm{DDD}$ & $\mathrm{DDE}$ & DDT & $\begin{array}{l}\text { Endo- } \\
\text { sulfar }\end{array}$ \\
\hline $06-17-87$ & $<0.01$ & 0.01 & $<0.01$ & 0.01 \\
\hline $07-23-87$ & .01 & .01 & .01 & .03 \\
\hline $08-20-87$ & $<.01$ & .01 & .01 & $<.01$ \\
\hline $09-24-87$ & $<.01$ & .01 & .01 & $<.01$ \\
\hline $10-29-87$ & $<.01$ & $<.01$ & $<.01$ & $<.01$ \\
\hline $11-24-87$ & $<.01$ & .01 & .01 & $<.01$ \\
\hline $01-12-88$ & $<.01$ & $<.01$ & $<.01$ & $<.01$ \\
\hline $01-28-88$ & $<.01$ & $<.01$ & .01 & $<.01$ \\
\hline $02-24-88$ & $<.01$ & .01 & $<.01$ & $<.01$ \\
\hline $03-30-88$ & $<.01$ & $<.01$ & .01 & $<.01$ \\
\hline $04-26-88$ & $<.01$ & $<.01$ & $<.01$ & $<.01$ \\
\hline $05-31-88$ & $<.01$ & $<.01$ & $<.01$ & $<.01$ \\
\hline $06-28-88$ & $<.01$ & $<.01$ & .01 & $<.01$ \\
\hline $07-27-88$ & $<.01$ & $<.01$ & .01 & $<.01$ \\
\hline $09-01-88$ & $<.01$ & $<.01$ & .01 & $<.01$ \\
\hline $09-29-88$ & $<.01$ & .01 & .01 & $<.01$ \\
\hline $10-26-88$ & -. & $\ldots$ & - & -- \\
\hline $11-29-88$ & -- & -- & -- & -- \\
\hline $12-21-88$ & $<.01$ & $<.01$ & .01 & $<.01$ \\
\hline
\end{tabular}


Table 13B.--Carbamate-insecticide concentrations in samples from wells sampled monthly in agricultural and undeveloped areas

[Values are in micrograms per liter (ug/L); well locations are shown in fig. 3]

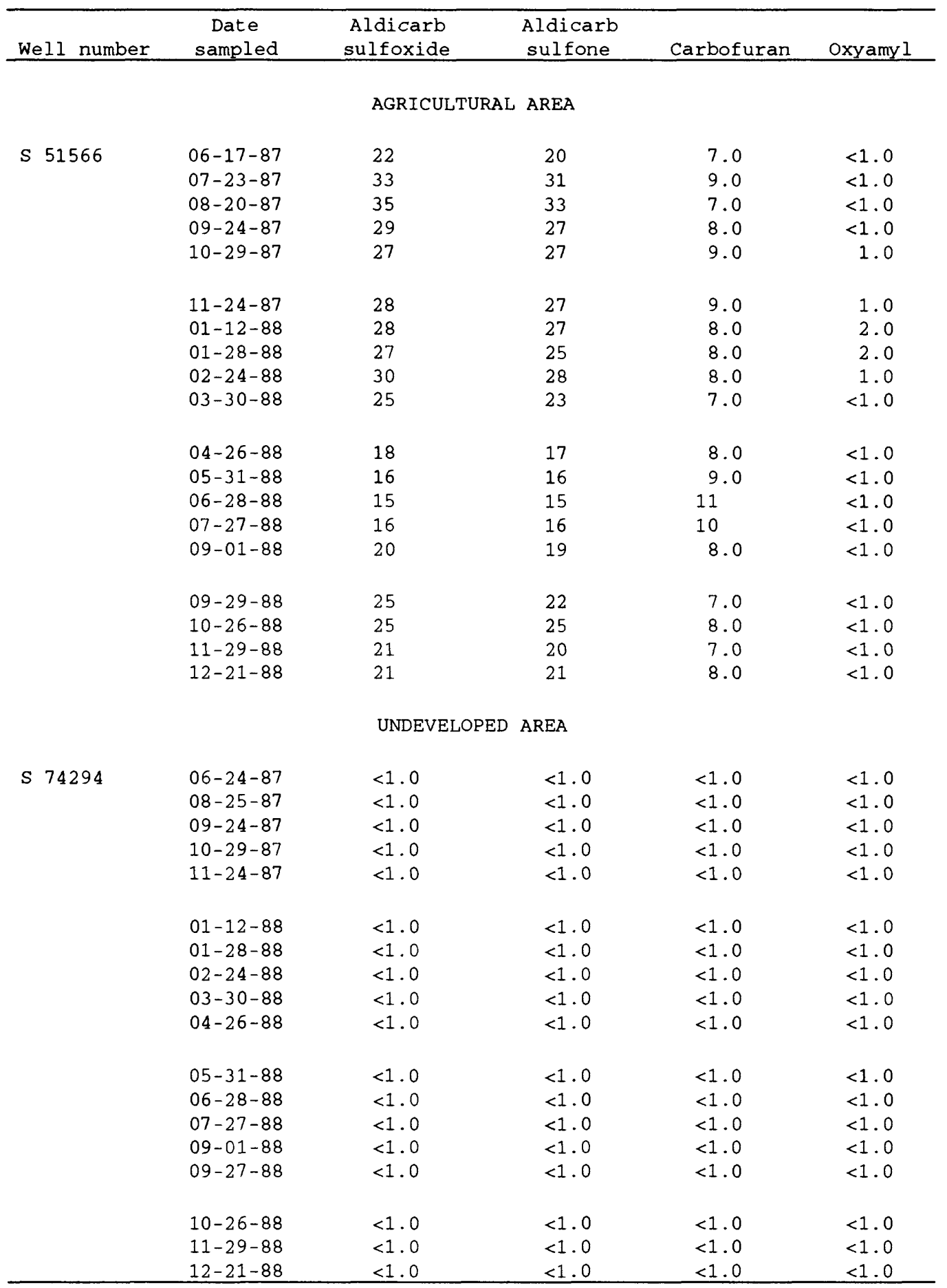

1 The following constituents were not detected (detection limit

$1.0 \mu \mathrm{g} / \mathrm{L})$ : Aldicarb, 3-Hydrolycarbofuran, Carbaryl, and Methomyl. 
Table 13C.--Organochlorine and organophosphorus insecticides and chlorophenoxy-acid and triazine herbicides not detected in water samples from well

sampled monthly in agricultural area

[Constituents are in micrograms per liter]

\begin{tabular}{cc}
\hline Constituent & $\begin{array}{c}\text { Detection } \\
\text { Limit }\end{array}$ \\
\hline
\end{tabular}

ORGANOCHLORINE INSECTICIDES

Aldrin

0.01

Chlordane

.1

Dieldrin

.01

Endrin

.01

Heptachlor

.01

Heptachlorepoxide

.01

Lindane

Methoxychlor

.01

Mirex

.01

Perthane

Polychlorinated biphenyls (PCB)

Polychlorinated naphthalenes (PCN)

.01

Toxaphene

1

1

1.0

ORGANOPHOSPHORUS INSECTICIDES

$\begin{array}{ll}\text { Diazinon } & .01 \\ \text { Ethion } & .01 \\ \text { Malathion } & .01 \\ \text { Methyl parathion } & .01 \\ \text { Methyl trithion } & .01 \\ \text { Parathion } & .01 \\ \text { Total Trithion } & .01\end{array}$

CHLOROPHENOXY-ACID HERBICIDES
$2,4-D$
$2,4-\mathrm{DP}$
01
$2,4,5-\mathrm{TP}$ (Silvex)
.01
$2,4,5-\mathrm{T}$
.01

TRIAZINE HERBICIDES

$\begin{array}{ll}\text { Alachlor } & .1 \\ \text { Ametryne } & .1 \\ \text { Atrazine } & .1 \\ \text { Cyanazine } & .1 \\ \text { Metolachlor } & .1 \\ \text { Metribuzin } & .1 \\ \text { Prometone } & .1 \\ \text { Prometryne } & .1 \\ \text { Propazine } & .1 \\ \text { Simazine } & .1 \\ \text { Simetryne } & .1 \\ \text { Trifluralin } & .1\end{array}$

1 Detection limit for chlorophenoxy-acid herbicides on 7-27-88 as follows: 2,4-D (0.1), 2,4-DP (0.1), Silvex $(0.02), 2,4,5-\mathrm{T}(0.02)$, Detection limit for triazine herbicides on 1-12-88 as follows: Metolachlor (0.2).

2 No triazine herbicide data available for 7-27-88, 10-26-88, 11-29-88, 12-21-88. 